\title{
Void Ab Initio: Application Fraud as Grounds for Avoiding Directors' and Officers' Liability Insurance Coverage
}

After thirty years, directors and officers ("D \& O") liability insurance is facing a major crisis. ${ }^{1}$ An unprecedented rise in the number of lawsuits against corporate directors and officers has led to an equally unprecedented number of claims on $\mathrm{D} \& \mathrm{O}$ policies. Often reaching into the tens of millions of dollars, these claims, even when settled, are leaving insurers grossly undercapitalized. Against a backdrop of generally adverse market trends im the insurance imdustry, the large number of claims has led many carriers to cancel existing policies, and others to discontinue underwriting $\mathrm{D} \& \mathrm{O}$ coverage altogether. Those corporations still able to secure coverage for their directors and officers face premiums and deductibles that often have tripled, im exchange for strippeddown coverage. ${ }^{2}$

It is not surprising, therefore, that bitter coverage disputes between D \& $\mathrm{O}$ imsurers and their corporate insureds, virtually unreported a decade ago, are multiplying. Critics of the insurance mdustry argue that much of the litigation arises from ambiguously worded imsurance contracts written in a soft insurance market. ${ }^{3}$ Wliatever the causes, corporations increasingly are taking their insurers to court to try to force them to pay. ${ }^{4}$

1. Lloyd's of London began marketing D \& O liability coverage in the mid-1950's, although the coverage did not receive attention until a decade later. American companies began to enter the market in the late 1960's. See Johnston, Corporate Indemnification and Liability Insurance for Directors and Officers, 33 Bus. LAw. 1993, 2012 (1978). As of 1984, approximately 98\% of all New York Stock Exchange companies surveyed possessed liability insurance for their directors and officers; among mutual companies, that figure reached $91 \%$, and for closely held companies, $64 \%$. Median coverage in 1984 was $\$ 6$ million for companies with assets under $\$ 25$ million; $\$ 25$ million for companies with assets between $\$ .4$ and $\$ 1$ billion; and $\$ 49$ million for companies whose assets exceeded \$2 billion. The WyatT Co., The 1984 WyatT Directors AND Officers AND Fiduciary Liability SURVEy SUMmaRy REPORT 18 (1985) [hereinafter 1984 WyatT SuRvey]. The Wyatt Company is a New York-based risk management consulting firm that since 1973 has conducted and published ten surveys analyzing the D \& $O$ insurance portfolios of major U.S. and Canadian corporations, hospitals, and educational institutions. The 1984 survey included 1652 corporate participants.

2. See infra Part I, Section $B$.

3. See, eg., Bishop, Understanding $D$ \& $O$ Insurance Policies, HARv. Bus. Rev., Mar.-Apr. 1978 , at 22.

4. See infra notes $132-48,160-62$ and accompanying text. 
One ground for nonpayment of $D \& O$ insurance claims is the corporate applicant's alleged misrepresentation on the policy application form. D \& O policy applications typically ask whether "any director or officer [has] knowledge or information of any act, error or omission which might give rise to a claim under tle proposed policy."5 If a lawsuit brought against the insurance company reveals that some director or officer in fact did possess sucl knowledge, the applicant's negative answer to this question could give the insurer grounds either to refuse coverage of the claim or to declare the policy void $a b$ initio.

This Comment will argue that the "preexisting knowledge clause" on the standard application for $D \& O$ liability insurance at best is an untrustwortlyy vehicle with which to elicit accurate information and to gauge insurability. At worst it presents an escape hatch for insurers intent on avoiding their obligations under the insurance contract. Until insurers and insureds hammer out a more reliable alternative to the preexisting knowledge clause, the courts sliould take a jaundiced view of insurers' use of the clause to avoid coverage.

Part I of this Comment will examine causes and effects of the current $D \& O$ insurance crisis. Part II will discuss the $D \& O$ policy application and the courts' failure to arrive at a consistent interpretation of the preexisting knowledge clause. Part III will analyze the difficulties of the clause as drafted. The clause is vague in scope and anbiguously worded. Moreover, it can produce the unconscionable effect of disallowing any claim based on a lawsuit whose originating act occurred prior to the application date. Because it is analogous to the preexisting illness clause found im most hife and health insurance policies, this Comment argues thiat the courts should apply to it the same burden of proof for breach. Part IV concludes by suggesting alternatives to the preexisting knowledge clause which would more accurately inform the insurer of specific risk exposure with less potential prejudice to the insured's right to coverage.

I

The Current Crisis in D \& O Liability UNDERWRITING

\section{A. The Causes}

\section{Insurance Industry Problems}

At least part of the current $D \& O$ insurance crisis can be attributed to the cyclical nature of the insurance industry itself $f^{6}$ and its belated

\footnotetext{
5. See infra note 157 and accompanying text.

6. When premiums are high, more companies will enter the market. In the fight for market share, a few will offer increased coverage at lower premiums, prompting the others to follow suit.
} 
emergence in 1984 from an unusually long soft-market period. The sixyear duration of the last period of competitive price-cutting ${ }^{7}$ left a pool of underwriters especially vulnerable to untoward developments in the corporate liability arena. ${ }^{8}$

Exacerbating the industry's woes has been the recent reduction in investment income-interest earned from premiums-which left insurers with markedly reduced assets against which to balance losses. ${ }^{9}$ Investment income is down sharply from 1982 levels, and those underwriters which had factored such income into their risk-evaluation formulae have faced unexpected shortfalls. ${ }^{10}$ As a result, policies are now priced exclusively on risk, with premium imcreases taking the place of investment income in the balancing formulae.

Transatlantic events also account for higher premiums and reduced capacity to insure. Lloyd's of London continues to provide a significant portion of the reinsurance for United States underwriters, and the steady drop in interest rates, combined with the pound's loss of value against the dollar, has caused Lloyd's to raise its premiums to Umited States insurers. ${ }^{11}$ For example, during the five months from November 1984 to

After a downward cycle usually lasting three years, premiums become low enough that losses force a number of carriers to discontinue underwriting that type of policy. This causes prices to rise, commencing the next upward swing of the cycle. See Heaney, The Crisis in Bank Insuranee Is Starting to Hurt, A.B.A. BANkING J., July 1985, at 54.

7. The downward trend coininenced in 1978 and lasted until mid-1984. 1984 WYATT SuRvey, supra note 1, at 31 . "This was the longest soft-market period in 30 years." Heaney, supra note 6, at 54; see also THE WyATT Co., THE 1985 SUPPLEMENTARY REPORT ON DiREcTORS \& OFFICERS LIABILITY INSURANCE 9 (1985) [hereinafter 1985 WYATT REPORT]. The 1985 report, involving 917 corporate participants, supplements the more comprehensive 1984 WYATT SURVEY, supra note 1 , by updating significant changes relating to policy limits, deductibles, and preiniums. 1985 WYATT REPORT, supra, at 1.

8. In actual prices, D \& O premiums in 1984 on average dropped to $56 \%$ of what they were in 1979. However, to keep up with marked increases during the same period in both frequency of clains and average claim severity, see infra notes $18-19$ and accoinpanying text, the 1984 rates should have been $267 \%$ of their 1979 level. 1985 WYATT REPORT, supra note 7, at 17. The combined effect of this unusually long downward price cycle and upsurge in claim-producing litigation was that premiums in 1984 were just $21 \%$ of what they should have been. Id.

9. Liability Insurers Are Fleeing Field in Wake of Big Damage Awards, L.A. Times, June 17, $1985, \S \mathrm{IV}$, at 1, col. 5 ("[I]nsurers, during a period of high interest rates, slashed rates to gain as much premium incoine as possible, expecting investment incoine to offset likely increases in insurance losses. Once interest rates fell, however, many coinpanies were left with insurance rates far below their probable exposure to risk.").

10. Heaney, supra note 6 . In 1985 alone, the insurance industry suffered a pre tax operating loss of $\$ 5.5$ billion. Farell, The Insurance Crisis: Now Everyone Is In a Risky Business, Bus. WK., March 10, 1986, at 88. This "eash-flow underwriting," as the technique is known, in part has left insurers "underreserved for future losses by as inuch as $20 \%$." Id.

11. Liability Insurance for Insiders Seen Becoming Expensive, Rare Commodity, Daily Rep. for Execs. (BNA) at A2 (Nov. 5, 1984). The same forces that have battered the American insurance market have also adversely affected the foreign reinsurance market. See, e.g., Thrift $D \& O$ Liability Coverage, Reinsurance Remains Scarce, 46 Wash. Fin. Rep. (BNA) 154 (Jan. 27, 1986); Farrell, supra note 10 , at 90 . 
March 1985, reinsurance premiums for financial-institution D \& O policies increased more than fifty percent. ${ }^{12}$ United States insurers, in turn, must pass along these increases to their corporate insureds.

\section{Explosion of $D \& O$ Claim-Producing Litigation}

The dramatic increase in disputes involving $D \& O$ insurance coverage is tied directly to an upsurge in the number of suits against corporate manageinent. ${ }^{13}$ A 1985 survey of 917 companies in the United States and Canada, for example, indicates that in the five years from 1980 through 1984 the frequency of D \& O lawsuits increased 58\%. ${ }^{14}$ While there has consistently been a high positive correlation between frequency of claims and company size, the greatest increase in D \& $\mathrm{O}$ claims filed during the 1980-84 period has been for the sinaller coinpanies. ${ }^{15}$ Although the banking, utilities, petrochemicals, steel, insurance, and computer industries have been the hardest hit, all sectors of corporate activity have felt soine impact. ${ }^{16}$ In $1984,18.6 \%$ of all corporations surveyed and $36 \%$ of corporations worth $\$ 2$ billion or more had experienced at least one $\mathrm{D} \& \mathrm{O}$ claim during the previous nine years. ${ }^{17}$

The severity of D \& $\mathrm{O}$ claims, as well as their number, also has increased drastically. The average cost of an award or settlement in 1984 stood at $\$ 1.3$ million, excluding legal defense costs, which themselves averaged $\$ 461,000{ }^{18}$ These figures represent a $69 \%$ increase since $1980 .{ }^{19}$

No single factor can account for the remarkable surge in corporate litigation in recent years. Rather, a combination of developinents, involving both old and new sources of liabihty, are responsible.

\section{a. Stockholder Actions}

Disgruntled stockholders remain the single largest source of clains

12. See Sudo \& Carroll, Negligence Suits Threaten Liability Coverage, Am. Banker, March 5, 1985 , at 3, col. 1 .

13. See Sudo, Liability Insurance Expected to be Hard to Find, Am. Banker, Oct. 22, 1984, at 49, col 1; Wollner, What to Look for in Directors and Officers Liability Insurance, MAG. BANK ADMIN., Dec. 1983, at 32.

14. 1985 WYATT REPORT, supra note 7, at 17; see also SEC Recommends Amending RICO to Require Unjustified Plaintiffs to Bear Fees, 45 Wash. Fin. Rep. (BNA) 516 (Oct. 7, 1985) (reporting that from 1975 through 1983, the average number of D \& O insurance claims increased over 270\%).

15. 1984 WYATT SURVEY, supra note 1 , at 6 .

16. See Schauer, Ailing $D \& O$ Insurance Market Looks for Cure, Bus. Law. Update, March/ Apr. 1986, at 1, col. 1 .

17. 1984 WYATT SURVEY, supra note 1 , at 6 .

18. Id. at 9. Legal defense costs for claims closed in 1984 averaged $\$ 250,000$. Id; see also Comment, Practical Aspects of Directors' and Officers' Liability Insurance-Allocating and Advancing Legal Fees and the Duty to Defend, 32 UCLA L. REV. 690, 694 (1985) (summarizing data from the Wyatt Company's 1982 survey).

19. 1985 WYATT REPORT, supra note 7, at 17. 
made against corporate management; shareholder actions, mcluding derivative and class action suits, represent at least forty percent of all $\mathrm{D} \& \mathrm{O}$ claims filed. ${ }^{20}$ These actions have been spurred in recent years by the proliferation of corporate mergers and acquisitions. Since 1980, more than 13,000 mergers and acquisitions have taken place. ${ }^{21}$ With the near doubling of the number of public shareholders in the past decade alone, ${ }^{22}$ even a friendly combination is likely to alienate some shareholder, and that shareholder may sue. A recent federal case, for example, noted that even a single takeover attempt imcreases D \& $O$ exposure to mimority stockholder hitigation. ${ }^{23}$

Corporate misadventures, too, lave spawned scores of shareholder suits agamst directors and officers: The 1970 Penn Central failure, the Three Mile Island and Bhopal accidents, ${ }^{24}$ the 1983 bankruptcy crisis enveloping thrifts in Ohio and Maryland, ${ }^{25}$ staggering loan losses by banks in their foreign lending and energy operations, ${ }^{26}$ cost overruns and licensing delays endemic to utility construction projects, ${ }^{27}$ and the asbestosis-claim crisis ${ }^{28}$ to name just a few. The enorinous damages sought by shareholders, as well as other victims of these misadventures, have sent directors, officers, and their insurers "running for cover."29

The judiciary itself has invited inore shareholder litigation by tightenimg professional standards for directors and officers. In the past, the bulk of shareholder derivative suits involved "classic breaches of fiduciary duties: self-dealing, conflict of interest, secret profits, waste of corpo-

20. See Sudo, supra note 13.

21. Bennett, Board Members Draw Fire, and Some Think Twice About Serving, Wall St. J., Feb. 5, 1986, at 18, col. 3. During the fourth quarter of 1985 alone, more than 1100 takeovers were announced. Hertzberg, Takeover Activity Slows as Stocks Surge, Wail St. J., Apr. 25, 1986, at 6, col. 1.

22. According to New York Stock Exchange Studies, in 197525.27 million Americans$11.9 \%$ of the population-owned stock investments. Portrait of the Stockholder FIN. WORLD, Jan. 10, 1984, at 54. By mid-1985 that number had increased to 47 million shareholders. Ownership of Stock Sets Record, San Diego Tribune, Dec. 4, 1985, at A19, col. 6.

23. See KDT Indus. v. Home Ins. Co., 603 F. Supp. 861,864 (D. Mass. 1985).

24. See Nelson \& Kerlow, Litigation Monitor, Legal Times, April 7, 1986, at 12, col. 1 (more than 100 suits filed against Union Carbide for Bhopal disaster, including series of derivative suits charging directors and officers with failure to protect corporation's long-term interests).

25. Ipsen, The Crisis in Directors and Officers Insurance, InSTITUTIONAL INVESTOR, Aug. 1985 , at $231,232$.

26. Id.

27. See, e.g., Paul, NRC Faults Lilco for Failing to Correct Problems at Plant's Radiochemistry Unit, Wall St. J., March 20, 1986, at 6, col. 1 (reporting the continuing safety "deficiencies" and stagnant progress toward licensing the Shoreham nuclear power plant).

28. See, e.g., Mitchell, Chapter 11 Filing by Raymark Is Seen Unless Suits, Insurance Problems Settled, Wall St. J., April 11, 1986, at 14, col. 1 (one asbestos company alone-Raymark Corp.currently faces 24,000 suits asking for billions of dollars); Mitchell, Thirteen Former Asbestos Firms to Settle Class-Action Suit for Over \$100 Million, Wall St. J., April 4, 1986, at 2, col. 1 (settling claims of only 751 plaintiffs).

29. Ipsen, supra note 25 , at 232. 
rate assets and the like."30 In the past decade, however, a number of courts have granted redress for far less egregious conduct. ${ }^{31}$ At the same time, the size of money judgments and settlements awarded in derivative and stockholder class action suits has grown significantly. ${ }^{32}$

Corporate management decisions traditionally protected under the business judgment rule's ${ }^{33}$ umbrella are becoming increasingly vulnerable to outside attack. ${ }^{34}$ In Smith v. Van Gorkom, ${ }^{35}$ the Delaware Supreme Court last year bypassed the business judgment rule and imposed personal hability on the directors of Trans Union Corporation for approving a cash-out merger at a price that was forty-five percent higher than the last closing price of the company's stock. ${ }^{36}$ Replacing its generally deferential attitude with a heavily process-oriented scrutiny of the board's deliberations, the court deemed the directors' endorsement of the merger proposal without adequate independent analysis a "grossly negligent."37 The extent of the nine directors' potential personal liability was dramatic, involving damages of almost $\$ 13$ million for each dollar difference between the tender-offer price and the stock's actual value. ${ }^{38}$ The decision, although it did not specifically reject or rewrite the business judg-

30. M. SchaefTler, The Liabilities of OfFicE: INDEMNIFICATION AND INSURANCE of CORPORATE OfFICERS AND DIRECTORS 1 (1976). Twenty years ago "[t]he ado about the liability of directors for mere negligence [was] like the proverbial shaving of pigs-much squeal and little wool ...." Bishop, Sitting Ducks and Decoy Ducks: New Trends in the Indemnification of Corporate Directors and Officers, 77 YALE L. J. 1078, 1095 (1968). Today, with the ever-expanding limits of directors' duties and damage awards, that pig's wool has become the golden fleece.

31. See, e.g., United States v. Park, 421 U.S. 658 (1975) (corporate president crininally liable for warehouse employees' violations of Federal Food, Drug \& Cosmetic Aet); Joy v. North, 692 F.2d 880 (2d Cir. 1982), cert. denied sub nom Citytrust v. Joy, 460 U.S. 1051 (1983) (outside directors' lack of knowledge not a defense to negligence liability); Federal Deposit Ins. Corp. v. MGIC Indemnity Corp., 462 F. Supp. 759 (E.D. Wis. 1978) (charging directors and officers with negligent acquiescence in misconduct of the bank's former president); Francis v. United Jersey Bank, 87 N.J. 15, 432 A.2d 814 (1981) (director personally liable for not noticing and preventing misappropriation of corporate trust funds).

32. See, e.g., Fox v. Chase Manhattan Corp., No. 8192-85 (Del. Ch. Dec. 6, 1985) (derivative action in which the court approved a settlement directing the payment by or on behalf of the defendant-officers of $\$ 32.5$ million).

33. The business judgment rule traditionally has operated as a shield to proteet directors from personal liability for their business decisions. See Sinclair Oil Corp. v. Levien, 280 A.2d 717, 720 (Del. 1971). The rule insulates the directors' decisions from second-guessing by courts as long as their decisions are made "on an informed basis, in good faith, and in the honest belief that the action taken [is] in the best interests of the company." Aronson v. Lewis, 473 A.2d 805, 812 (Del. 1984).

34. See Greene \& Palmiter, Business Judgment Rule Tightened for Takeovers, Legal Times, Jan. 20, 1986, at S3, col. 1 .

35. 488 A.2d 858 (Del. 1985).

36. Id. at 876 .

37. Id. at 884 .

38. See id. at 864 n.3. The litigation ultimately was settled, with payment of $\$ 23.5$ million to the plaintiff class. Of that amount, $\$ 10$ million, the full policy limit, was paid by Trans Union's D \& $\mathrm{O}$ insurer. See Manning, Reflections and Practical Tips on Life in the Boardroom After Van Gorkom," 41 Bus. LAw. 1 (1985). Although most of the remainder was paid by the Pritzker family, which acquired Trans Union, "at least some of the settlement money came out of the pockets of the 
ment rule, nevertheless "has provoked intense concern in many corporate boardrooms," 39 leadimg some to fear that "judges will now be able to second-guess directors' decisions made in control fights to ensure 'fair value' to shareholders." 40

In two subsequent decisions, the Delaware Supreme Court further tightened the busmess judgment rule in relation to corporate defensive measures taken in response to a takeover threat or to ward off future threats. ${ }^{41}$ In such situations, because the director's duty is "enhanced" by the "omnipresent specter that a board may be actmg primarily in its own imterest, rather than those of the corporation and its shareholders," 42 the Court has shifted the initial burden of proof of the reasonableness of the board's decision to the directors. ${ }^{43}$ More recently, the Second Circuit in Hanson Trust PLC v. ML SCM Acquisition, Inc. ${ }^{44}$ examined New York's version of the business judgment rule in corporate takeover fights, and concluded that it too expects to see a heightened degree of diligence in director decisions likely to affect shareholder welfare and the "corporation's ultinuate destiny."45 Whereas the Van Gorkom court measured the directors' due care agamst "concepts of gross neghgence," gence standard. ${ }^{47}$

The effect of these recent decisions on D \& O clainis is twofold. The

individual directors-including one who was in the hospital during the transaction." Victor, Rhetoric Is Hot When the Topic is Takeovers, Legal Times, Dec. 23/30, 1985, at 2, col. 3.

39. Olson \& Morgan, $D \& O$ Exclusions Extend to Takeover Context, Legal Times, March 10, 1986, at 23, col. 1; see also Rovner, $D \& O$ Indemnity, Legal Times, Nov. 25, 1985, at 1, col. 3 (noting the added "scare value" of the decision, since the transaction was not a hostile takeover, and the directors had no personal interest).

40. Greene \& Palmiter, supra note 34, at S3, col. 3.

41. Unocal Corp. v. Mesa Petroleum Co., 493 A.2d 946 (Del. 1985); Moran v. Household Int'l, Inc., 500 A.2d 1346 (Del. 1985).

42. Unocal, 493 A.2d at 954 .

43. The directors must show both that they had "reasonable grounds for believing that a danger to corporate policy and effectiveness existed," and that the defensive measure was "reasonable in relation to the threat posed." Moran, 500 A.2d at 1356 (quoting Unocal, 493 A.2d at 955). Once this two-pronged burden is satisfied, the burden of proof of the directors' breach shifts back to the plaintiff. Id.

44. 781 F.2d 264 (2d Cir. 1986). In Hanson, the court reversed a lower court denial of a preliminary injunction prohibiting the target from exercising an asset lock-up option as a defense against a series of any-and-all cash tender offers by Hanson. Id. at 266-67. For an analysis of Hanson, Unocal, and Moran, see Lesser, Directors, Nat. L.J., Feb. 24, 1986, at 1, col. 1.

45. Hanson, 781 F.2d at 277 (quoting Norlin Corp. v. Rooney, Pace, Inc., 744 F.2d 255, 258 (2d Cir. 1984)).

46. Smith v. Van Gorkom, 488 A.2d 858, 873 (Del. 1985).

47. Hanson, 781 F.2d at 275. Consequently, even though the board had consulted with a leading investment banker-who confirmed that the options were valued fairly-the court still held that the board failed its duty to become adequately informed before acting. See Green \& Palmiter, supra note 34, at S3, col. 3 ("The metamorphosis is not yet complete, but the language and results of recent decisions seem clear: Passivity has been replaced by scrutiny and deference by skepticism.") 
tightening of the business judgment rule may increase not only a director's ultimate exposure to liability, but also his litigation expenses, as courts become less willing to resolve actions in favor of the directors at an early stage of the proceeding. Both liability exposure and litigation expenses, of course, directly impact the ultinate cost and availability of D \& O coverage.

\section{b. Other Private Actions}

D \& O insurance origmally was sold primarily for protection against stockholder suits. ${ }^{48}$ Today fully sixty percent of claims filed against corporate directors and officers come from sources other than shareholders. ${ }^{49}$ This latter collection of claims springs from a wide range of sources including employees, former employees, customers, the government, ${ }^{50}$ prior owners of an acquired company, competitors, creditors, and contractors. ${ }^{51}$ Consumer-oriented legislation at state and federal levels, often including provisions for private actions, has increased the variety and frequency of $\mathrm{D} \& \mathrm{O}$ claims. Causes of action grounded in expanding theories of product habihity, failure to comply with the Consumer Product Safety Act, the Equal Employment Opportunity Commission, or Occupational Safety \& Health Administration standards, tort claims for pollution, and violations of civil rights represent just a few. ${ }^{\mathbf{5 2}}$

A prime example of expansive legislation is the Racketeer Influenced and Corrupt Organizations Act of 1970 (RICO) ${ }^{53}$ which provides for private civil actions and allows recovery of treble damages upon showing injury from "racketeering activity." ${ }^{54}$ Although initially drafted to combat organized crime, the statute has been so broadly interpreted by the courts-most recently by the Supreme Court ${ }^{55}$ - that today the vast

\footnotetext{
48. 1984 WYATT SURVEY, supra note 1, at 10.

49. See Sudo, supra note 13, at 49.

50. Claims by governmental agencies are discussed infra at notes 67-73 and accompanying text.

51. 1984 WYATT SURVEY, supra note 1, at 10; see also Sudo, supra note 13, at 49 . The following are the principal types of allegations in $D$ \& $O$ claims made by all sources, including shareholders, in order of frequency: misleading representations (18.9\%), collusion or conspiracy to defraud $(9.1 \%)$, breach of duty to minority stockholders $(7.4 \%)$, failure to honor employment contract $(7.2 \%)$, civil rights denial or discrimination $(7.2 \%)$, interference with contractual rights (7\%), and antitrust violations (6.1\%). The remaining $37 \%$ of claims involve a variety of "other," less frequent allegations. 1984 WYATT SURVEY, supra note 1, at 10.

52. Greenberg \& Dean, Protecting the Corporate Executive: Director and Officer Liability Insurance Reevaluated, 58 MARQ. L. REV. 555, 557-58 (1975).

53. 18 U.S.C. $\S \S 1961-1968$ (1982).

54. Id. $\$ 1961(1)$.

55. Sedima, S.P.R.L. v. Imrex Co., Inc., 105 S. Ct. 3275 (1985). In Sedima, plaintiff corporation sued its former joint-venture partner and two of that corporation's officers under RICO, alleging acts of mail and wire fraud. In affirming the dismissal of the case, the Second Circuit attempted to rein in the perceived overexpansive use of RICO by private litigants by restricting actions to only those against defendants who had been convicted on criminal charges, and only
} 
majority of private RICO actions are brought against "respected and legitimate "enterprises." "56 The number of claims brought under RICO has skyrocketed in the past two years. ${ }^{57}$ The relatively vague language of the statute is such that "[i]t seems no exaggeration to say that almost any transaction imvolving two mailings or telephone calls which are arguably false may be the basis for a federal court claim under civil RICO."58

\section{c. Insider Suits}

A recent phenomenon described by one insurance official as "the nail in the coffin" "59 of the D \& O hability insurance industry is the insider suit. In these actions, corporations sue their own directors and officers for mismanagement or negligence. The corporation then files a claim with the D \& O msurer for reimbursement of any judgment agamst the corporation, plus hitigation costs. ${ }^{60}$

Chase Manhattan Bank broke ground in 1984 with this innovative action, sumg six former employees to recover $\$ 175$ million im loan losses caused by the 1982 collapse of the Penn Square Bank. ${ }^{61}$ More recently,

where there was a "racketeering injury." Sedima, S.P.R.L. v. Imrex Co., Inc., 741 F.2d 482, 496 (2d Cir. 1984), rev'd 105 S.Ct. 3275 (1985). The Supreme Court reversed, rejecting both restrictions and soundly affirming a continued broad reading of civil RICO. 105 S.Ct. at 3287.

56. Sedima, 741 F.2d at 487 . Only $9 \%$ of all reported civil RICO cases reported alleged acts "normally associated with professional criminal activity." Fully $40 \%$ alleged "securities fraud" and $37 \%$ alleged "fraud in a commercial or business setting." Sedima, 105 S.Ct. at 3295 (Marshall, J., dissenting). "Those companies sued under the statute constitute a virtual who's who of banks, brokerage houses and accounting firms." Ipsen, supra note 25, at 233.

57. "Of 270 district RICO decisions prior to [1985], only $3 \%$ (nine cases) were deeided throughout the 1970's ... and 43\% in 1984." Sedima, 105 S. Ct. at 3277, n.1. The Department of Justice estimates that through 1985 more than 500 RICO suits had been filed. Latimer, Lower Courts See Solution to the RICO Avalanche, Legal Times, Jan. 27, 1986, at 8, col. 1; see also Bradley, Long Arm of the Rackets Law Draws Fire From White Collar Targets, Christian Science Monitor, Feb. 7, 1986, at 21 ("According to a [Securities Industry Association] survey of 145 securities firms, 410 of the 1730 cases pending against them included RICO allegations.").

58. Sedima, 105 S. Ct. at 3294 (Marshall, J., dissenting). RICO plaintiffs are lured not only by the prospect of treble damages and attorneys' fees, but also by the tremendous settlement value of a RICO claim. In addition to the financial exposure, the public ignominy of being labelled a "racketeer" pressures corporate defendants to settle quietly out of court. Latimer, supra note 57, at 8, col. 3; see also Sedima, 105 S. Ct. at 3294 (Marshall, J., dissenting). Moreover, critics of the act point out that RICO allows a plaintiff to bypass numerous state common law and federal law requirements for private actions, such as proof of standing, culpability, causation, reliance, and materiality, especially in the area of securities and commodities laws. Sedima, 105 S. Ct. at 3295 (Marshall, J., dissenting).

59. Sudo \& Carroll, supra note 12.

60. Id.

61. Lewin, Business and the Law; Bank Aides and Insurers, N.Y. Times, May 7, 1985, at D2, col. 1. In October, 1984, the New York State Supreme Court refused to dismiss the suit. Sudo \& Carroll, supra note 12. The dispute subsequently was settled before a Delaware court on Dec. 6, 1985; the insurers, led by Home Insurance Company, agreed to pay Chase $\$ 32.5$ million. Experts predict the settlement will "aggravate" coverage problems for American businesses. Sloane, InsurerManagement Liability Rift Seen Growing, N.Y. Times, Dec. 19, 1985, at D8, col. 1. 
Bank of America commenced action against six former employees for losses stemming from a mortgage-backed securities scandal that led the bank to take a $\$ 95$ million charge agamst 1984 earnings. ${ }^{62}$ BankAmerica at the time was insured by two D \& O underwriters for $\$ 100$ million. $^{63}$ The suit, filed im Feburary 1985 in Los Angeles Superior Court, also named both insurers. ${ }^{64}$

Several banking and insurance experts have noted that both banks are using their lawsuits primarily as a vehicle to recover their losses from their insurers. ${ }^{65}$ The underwriters themselves are livid, asserting that $D$ \& O hability coverage was designed solely to cover claims against corporate officials by third parties, not the corporation itself. ${ }^{66}$

\section{d. Regulatory Agency Claims}

Another reason for the insurance chaos is the marked increase in claims made on $\mathrm{D} \& \mathrm{O}$ pohicies by governmental and regulatory agencies, such as the Federal Deposit Insurance Corporation (FDIC) and the Federal Savings and Loan Insurance Corporation (FSLIC). The FDIC, acting in its role as hquidator or trustee of a failed bank, treats the D \& O pohicy as a bank asset. Recently the agency has been filing D \& $O$ insurance claims on behalf of over two-thirds of the failed banks it takes over. ${ }^{67}$ This more aggressive posture, combined with the record number of bank failures in the past two years-79 in 1984 and 120 in 1985-has strongly contributed to make banking corporations among the most diffi-

62. Lewin, supra note 61.

63. These were Employers Insurance of Wausau, Wisconson, and First State Insurance Company of Boston. Hooper \& Brennan, BankAmerica Has $\$ 60$ Million Paraguay Loss, Am. Banker, March 25, 1985, at 1, col. 4.

64. Id.

65. See Pollack, Lawyer Says Coast Bank Sued to Get Insurance, N.Y. Times, March 4, 1985, at D6, col. 1 ("[t]he bank makes little secret of the fact"); Sloane, supra note 61. First, it is unrealistic to assume that the individual employees would have a net worth approaching $\$ 95$ million. Second, although the banks validly could have alleged fraud against their employees, both alleged negligence; not coincidentally, D \& $O$ policies as a rule exclude coverage for intentional misconduct. See Lewin, supra note 61.

66. See Pollack, supra note 65; see also Schauer, supra note 16, at 2 (insurers contend they were never meant to "be guarantors of bank loans to third world countries, assume responsibility for the drop in world oil prices, or fund the bail-out of the American farmer").

The Wausau Insurance Company has denied liability to BankAmerica and is fighting back through the courts. See Sloane, supra note 61 . The distinction between insider and third-party status in this case may be moot since, subsequent to BankAmerica's action, a shareholder filed a derivative suit against the bank's top ten officers, seeking $\$ 95$ million for the same losses; the shareholder's claim, however, also seeks recovery for $\$ 60$ million in loan losses to Paraguay, for a total claim of $\$ 155$ million. See Hooper, Shareholder Sues Top Executive of BankAmerica, Am. Banker, June 10, 1985, at 3, col. 1.

67. Heaney, supra note 6, at 56; see, e.g., FDIC v. Bird, 516 F. Supp. 647 (D.P.R. 1981); FDIC v. National Union Fire Ins. Co., 1977-1979 Fire \& Casualty Cas. 1302 (N.D. Ohio 1979); FD1C v. MGIC Indemnity Corp., 462 F. Supp. 759 (E.D. Wis. 1978); FDIC v. Franks, 473 So. 2d 1018 (Ala. 1985); FDIC v. American Home Assurance Co., 585 S.W.2d 756 (Tex. Civ. App. 1979). 
cult to insure. ${ }^{68}$

Sinilarly, FSLIC, in the wake of congressional complaints about that agency's misinanageinent and waste, has responded with a spate of lawsuits agamst the manageinent of failed thrifts. ${ }^{69}$ The agency seeks to recoup bailout costs and shore up its own reserves by using these lawsuits as a vehicle to collect on the thrifts' D \& O habihty coverage. ${ }^{70}$ As of July 1985, FSLIC had filed more than twenty-five suits against directors of failed savings and loans. ${ }^{71}$ The enforcement division of the Federal Home Loan Bank Board has also stepped up cases against thrift insiders, stating that it intends to pursue officials who have already resigned in hopes of avoiding liability. Here too congressional pressure is spurring the agency to get tough with insiders. ${ }^{72}$

Financial institutions are not the only corporations feeling the heat of an increase in governmental agency suits. Corporations of all sizes and in all fields have been subject to a rising nuinber of lawsuits by public entities, includimg city planning commissions, state boards of corporations, franchise tax boards, the Department of Justice, and the IRS. ${ }^{73}$

\section{B. The Effects}

\section{Upon Underwriters}

One commentator has noted that, "In the normal parlance of insurance underwriting, msurers generally conclude that when the risk is out of control, as it is getting here, it is not worth covering."74 Many insurers have stopped selling D \& O coverage altogether. ${ }^{75}$ Employers Insur-

68. Heaney, supra note 6, at 56; see also Comment, Banking Disclosure Regimes for Regulating Speculative Behavior, 74 CALIF. L. REv. 431, 442 n.53 (1986)(noting bank failures since 1985). FDIC's astounding losses from these recent bank failures has heightened its desire to reach the banks' D \& O policies. See, e.g., FDIC's Loss on Butcher Failures Hits $\$ 538$ Million; Agency's Costs As of June 30 Far Exceed Estimates; Total Could Reach \$1 Billion, Am. Banker, Sept. 25, 1984, at 16 , col. 2.

69. See Criticism of FSLIC Prompts Surge in Lawsuits Against S\&L Directors, WASH. FIN. REP. (BNA), 95 (July 15, 1985).

70. FSLIC losses in 1984 totalled $\$ 400$ million. Id.; see also Wynter, Agency Sends More Thrift Examiners to the Southwest, Wall St. J., March 20, 1986, at 56, col. 1 (216 financially troubled thrifts nationwide currently threaten the solvency of FSLIC).

71. See, e.g., FSLIC v. Williams, 599 F. Supp. 1184 (D. Md. 1984); FSLIC v. Bass, 576 F. Supp. 848 (N.D. Ill. 1983); FSLIC v. Huff, 237 Kan. 873, 704 P.2d 372 (1985).

72. See Liability Insurance for Insiders Seen Becoming Expensive, Rare Commodity, supra note 11.

73. “NAS-INSURANCE," Business Wire, July 29, 1985 (press release available on NEXIS). A single act of price-fixing by a corporate official, in addition to giving rise to private actions for treble damages under the Sherman Act and various state statutes, may result in public suits by the U.S. Department of Justice, the Federal Trade Commission, and state Attorneys General for a variety of relief including inearceration, financial penalties, and injunctions.

74. Sudo, supra note 13 , at 49.

75. In 1984, brokers could choose from more than thirty carriers. By early 1986 "only a handful" remained. Schauer, supra note 16, at 1; see also 1985 WYATT REPORT, supra note 7, at 25 - 
ance of Wausau, for example, which in late 1983 was characterized as "aggressively soliciting [the D \& O insurance] business," 1985 had abandoned the market entirely. This trend has severely limited the industry's overall capacity to meet the demand for D \& $O$ insurance. ${ }^{77}$

Those still selling insurance are raising their premiums tremendously. In 1985 alone, premiums for renewed D \& O insurance increased an average of $362 \%{ }^{78}$ Corporate risk managers in some industries faced premium increases fully ten times what they were the previous year. ${ }^{79}$ Excess layers of insurance contained even bigger premium increases. ${ }^{80}$ Insurers raised average deductibles $33 \%$ in 1984 and another $88 \%$ in $1985 .{ }^{81}$ Concurrently, average coverage capacity-the overall policy limits-decreased for 1985 renewals by more than $30 \% .^{82}$ The excess-market insurers remaining are only taking about one-half the line they took a year earher. ${ }^{83}$

In addition to raising premiums and deductibles, and reducing capacity, insurers are broademing existing exclusions from coverage and drafting new ones. D \& O policies traditionally have expressly excluded from coverage claims involving libel or slander, gains in personal profit, section $16(\mathrm{~b})$ violations, ${ }^{84}$ adjudged dishonesty, failure to maintain insur-

31 (listing underwriters who have stopped accepting new D \& $O$ applicants or who have quit the market).

76. Wollner, supra note 13 , at 32 .

77. See Bennett, supra note 21 ("Alexander \& Alexander, Inc., a big insurance broker, estimates that insurers are filling only a quarter of the demand for such [D \& $O$ ] coverage ....").

78. Insuring Directors, Wall St. J., March 21, 1986, at 25, col. 3. Premiums for insurance companies themselves rose $431 \%$; for service companies, $420 \%$; for industrials, $365 \%$; for retailers, 337\%; for banks and other financial institutions, $271 \%$. Id. The 1985 premium increase for banks is lower than the other cited industries only because banks entered the year having already borne substantial premium hikes during 1984. See Sudo \& Carroll, supra note 12, at 3 (citing the 1982 failure of the Penn Square Bank as precipitating the insurance crisis in that industry).

79. Ipsen, supra note 25, at 232; Fowler, Careers: Scarce Corporate Directors, N.Y. Times, Jan. 7,1986 , at D20, col. 1. The "high risk" industries include petroleum, banking and utilities. 1985 WYATT REPORT, supra note 7, at 9. The Wyatt Company notes several "anecdotal incidents" of 1985 premium hikes, including one public utility which reported a " $600 \%$ increase in premium, for one-tenth the policy with a 50 fold increase in deductible." Id. at 17.

80. 1985 WYATT REPORT, supra note 7, at 6 . For example, excess premium rates doubled in the second half of 1984, and then tripled that level in the first half of 1985. Id.

81. Id. at 10.

82. Id. at 9; see also Schauer, supra note 16 , at 1 ("In $1984, \ldots$ limits of up to $\$ 200$ million were available. Today . . \$50 million in coverage is a realistic maximum in standard market coverage.").

83. Securities Exchange Act § 16(b), 48 Stat. 881 (1934)(codified at 15 U.S.C. § 78p(b) (1983)). 1985 WYATT REPORT, supra note 7, at 10. Between 1984 and mid-1985 the average excess layer written dropped from $\$ 15$ million to about $\$ 12.5$ million per layer; numerous excess markets have completely dried up. Id.

84. See M. SchaefTLER, supra note 30 , at $277-84$ (reprinting the D \& O policy of National Union Fire Ins. Co. of Pittsburgh, Pa.). Typically the policy excludes coverage of any suit against an insured "for an accounting of profits in fact made from the purchase or sale by the Insureds of 
ance, and otliers. ${ }^{85}$ Endorsements attached to the policy also may exclude reimbursement for sucli things as nuclear energy hability, pollution fines, and Employment Retirement Income and Security Act claims. ${ }^{86}$

Heightened risk exposure has precipitated the imposition of new coverage exclusions and restrictions. For example, policies often now expressly exclude coverage for insider suits, ${ }^{87}$ suits brought by regulatory agencies, ${ }^{88}$ claims arismg from public offerings, ${ }^{89}$ and employee liring and firing disputes. ${ }^{90}$ One recent federal district case refused to give effect to a $\mathrm{D} \& \mathrm{O}$ policy provision purporting to exclude coverage of any claim arismg from an attempt "to gain control" of the corporation by merger or acquisition. "91 "Hostile takeover" exclusions, which operate on claims arising from defensive actions by the takeover target, are now common. ${ }^{92}$ Moreover, whereas the typical policy's standard term of coverage was three years, with renewals routmely granted, today there is a strong trend toward one-year policies with a stated expiration date. Finally, the mandatory $5 \%$ coinsurance participation by insureds, which insurers had dropped for many years, is once agam incorporated in many policies. ${ }^{93}$

\section{Upon Corporations}

\section{a. Over the Barrel}

The resulting bind for corporations is that although coverage is becoming harder to find, the need for coverage is increasing. In today's litigious climate it is important that firms cover all directors and officers at the holding-company and majority-owned subsidiary levels, and pref-

securities of the Company ... within the meaning of section 16(b) of the Securities Exchange Act of 1934 and amendments thereto or similar provisions of any state statutory law." Id. at 282.

85. See The WyatT Co., ANalysis of Directors and OfFicers Liability Policies 12-

17 (1984) [hereinafter WyaTt PoliCY ANALYSIS].

86. Id.

87. See Sloane, supra note 61, at D8, col. 5; see also Brenner, Liability Insurance Pool Drying $U_{p}$ for Banks, Am. Banker, April 8, 1985, at 7, col. 3. Insider suits are discussed supra at notes 5966 and accompanying text.

A recent case has held that the insider suit exclusion does not necessarily bar the FDIC-as assignee of a failed bank's assets-from suing the bank's directors and officers. See Federal Deposit Ins. Corp. v. National Union Fire Ins. Co., 630 F. Supp. 1149 (W.D. La. 1986) (denying insurer's motion for summary judgment).

88. See Schauer, supra note 16, at 1. Regulatory agency suits are discussed supra at notes 6773 and accompanying text.

89. See WVyATT POLICY ANALYSIS, supra note 85.

90. Id.

91. KDT Indus., Inc. v. Home Ins. Co, 603 F. Supp. 861 (D. Mass. 1985).

92. Olson \& Morgan, D\& O Exclusions Extend to Takeover Context, Legal Times, March 10, 1986 , at 28 , col. 2.

93. See Schauer, supra note 16 , at 1 . 
erably directors serving on outside boards as well. Nevertheless, the unavailability of D \& O coverage, sometimes at any price, is forcing some corporations for the first time to "go bare."94 Currently, because underwriters are cancelling policies or raising premiums beyond companies' ability to pay, only one-quarter of the demand for $D \& O$ coverage is being filled. ${ }^{95}$

The inarket is so tight, in fact, that corporations with policies still in force are being advised to take unusual steps to increase the cliances that msurers will renew. These steps include refraining from "shopping around" (Lloyd's, the major remsurer, frowns upon having to develop multiple proposals for a single insured); ${ }^{96}$ choosing a single broker to carry out the entire marketing effort; ${ }^{97}$ offering to take higher deductibles (thus impressing the insurer with management's confidence it will not be sued); ${ }^{98}$ and filing for renewal at least three months before expiration. ${ }^{99}$

More ominous is the chilling effect of increased liability and decreased coverage upon corporate directorates. These factors are deterring able men and women from serving as corporate directors, ${ }^{100}$ and have induced incumbent directors to resign. ${ }^{101}$ Should those directors

94. Loomis, Naked Came the Insurance Buyer, FORTUNE, June 10, 1985, at 67 ("Going bare is the term for operating alone without property and casualty coverage. In a litigious world, it's a chilly, unwelcome and expensive experience for corporations."). In 1985, nearly 15\% of all U.S. Chamber of Commerce members surveyed could not obtain any liability coverage at all, and " 7 in 20 [were] considering going bare." Farrell, supra note 10, at 88.

95. Bennett, supra note 21 , at 18.

96. Betterly, Hanging On to Your Officers' Liability Protection, Am. Banker, Dec. 20, 1984, at 4 , col. 1 .

97. 1985 WYATT REPORT, supra note 7, at 33.

98. Betterly, supra note 96.

99. Id.

100. See Bennett, supra note 21 , at 18 ("[O]ne company in five was turned down by a boardroom prospect in 1985 . That rejection rate was the highest in recent years . . . . Today, the first question is, 'What is your liability coverage?" "); Fowler, Scarce Corporate Directors, N.Y. Times, Jan. 7, 1986, at D20, col. 1 (noting the "increasing reluctance to serve because of the growing problem of the cost and availability of liability insurance"); Sloane, Insurer-Management Liability Rift Seen Growing, N.Y. Times, Dec. 19, 1985, at D8, col. 1 (" "The result is you're going to drive companies to inside boards of directors." "); see also Shapiro v. American Home Assurance Co., 584 F. Supp. 1245, 1251 (D. Mass. 1984) ("[T]he recent increase in corporations seeking D \& O insurance is in part a response to the reluctance of outsiders to serve as directors without some protection against personal liability."). See generally M. SCHAEFTLER, supra note 30 , at 2, 35 .

101. See, e.g., Lear Petroleum Says Four Directors Quit After Insurance Lost, Wall St. J., Feb. 18, 1986 at 20, col. 3; Bennett, supra note 21, at 18 (Four directors of Torotel Inc., a telecommunications equipment manufacturer, quit after that corporation lost its $D$ \& $O$ insurance in late 1985.); Crutcher's Chairman and 3 Directors Quit; Lack of Insurance Cited, Wall St. J., Feb. 12, 1986, at 21, col. 2; Pollack, An Era Ends at Control Data, N.Y. Times, Jan. 11, 1986, at 19, col. 2 ("[Threc] directors have resigned recently . . . because the liability insurance for directors and officers was cancelled."); Seiscom Delta Says Its Chief, 5 Directors Quit, Wall St. J., Nov. 29, 1985 at 6 , col. 3 (noting the resignation of 4 of 5 outside directors of Verna Corp., a contract drilling company, after D \& $O$ insurance was withdrawn); [Continental] Steel Company Resignations, N.Y. Times, Sept. 24, 1985, at D4, col. 6 (chairman and seven outside directors resign from twelvemember board). 
remaining on an uninsured board become decidedly more risk-averse in their decisionınaking and governing roles, "the enterprise system itself will be the loser." 102

\section{b. Captive Insurers}

One unorthodox corporate solution to the D \& O insurance problem, albeit available only to relatively few firnis, has been to create a wholly-owned insurer subsidiary. After it could not find coverage anywhere in the insurance market, BankAmerica created its own offshore insurance arm-B.A. Insurance (Cayman) Ltd.-to ensure stable coverage for its directors and officers. ${ }^{103}$ Not long thereafter, Bank of California set up a Cayman Islands subsidiary to supply similar coverage. ${ }^{104}$

Economically this insurance arm is no different than self-insurance. However, special problems arise with self-insurance in the $\mathrm{D} \& \mathrm{O}$ policy context. Most important, the practical effect of a successful sliareholders' suit against corporate officers is that any damages awarded will be remibursed out of sliareholder assets. ${ }^{105}$ This situation not only creates a financial catcli-22 for the sliareholders, but also conflicts with statutory and public policy prohibitions agamst self-indemnification. ${ }^{106}$ Although the current trend of state law lias been to allow a corporation through outside D \& $\mathrm{O}$ insurance to indemnify director or officer misconduct

102. Johnston, supra note 1, at 1993-94, 2035 (citing "the need to protect aggressive managers who are willing to take good-faith risks in the search for profits"); see also Herzel, Law Should Allow Indemnity for Derivative Suits, Legal Times, Mar. 31, 1986, at 11, col. 1 ("Directors already have a bias toward being more cautious than is optimal for society-that is, they take less risk than ownermanagers would. . . . It is therefore in the interest of society not to force on directors an added incentive to be too cautious. These undesirable effects are greatest on new, growing coinpanies."); Ipsen, supra note 25, at 233 (noting a corporate board that aborted a prospective merger transaction after it lost its D \& O coverage). But see Perry, Bank Liability Insurance Crisis: Feds Opt To Hold Their Breath, Ain. Banker, Sept. 3, 1985, at 17, col. 1 (noting the "silver lining" to the crisis in the banking industry: outside directors will eventually "take a more active interest in a bank's operations").

103. Brenner, BankAmerica Captive Offshore Insurer Raises Legality and Proprietary Questions, Am. Banker, Apr. 26, 1985, at 1, col. 2.

104. Brenner, Regulators Let BankAmerica Keep Its Captive Insurer, Am. Banker, July 22, 1985, at 23, col. 2 .

105. This is most apparent in a derivative action (the corporation recovers damages and then reimburses the defendants), but even a stockholder's direct or class action (the shareholders recover damages and the corporation they own reimburses) operates with the saine, though inore subtle, circularity of result. See Oesterle, Limits on a Corporation's Protection of Its Directors and Officers from Personal Liability, 1983 WIS. L. REV. 513, 573-74 nn.207-08. Since Bank of California has only one stockholder-Mitsubishi Bank Ltd.-it is not as vulnerable to self-indemnification public policy concerns. Brenner, supra note 104.

106. See Johnston, supra note 1, at 2005-12. Many states prohibit corporations from indemnifying their directors and officers against awards in derivative suits. See, e.g., DEL. CODE. ANN. tit. 8, § 145(b) (1983). Likewise, the Securities and Exchange Commission holds it against public policy for a securities registrant to indemnify its registration statement signators for any false or misleading information it may contain. See, e.g., ltem 512(i) of Regulation S-K, 17 C.F.R. $\S 229.512$ (1985). 
which it could not insure directly, ${ }^{107}$ in the case of a captive insurance company the distinction between insurer and corporation collapses. Other concerns include whether a $100 \%$-owned captive insurer would afford a protected source of funds in the event of the parent's bankruptcy and whether premiuins paid to the captive would give the parent any tax benefit. ${ }^{108}$ Although these issues are not yet resolved, the offshore captives established to date have passed technical muster with state and federal regulators, and have been declared bona fide insurance companies. ${ }^{109}$

It is also uncertain whether an individual firn's captive insurer can obtam adequate reinsurance, today a virtual necessity for institutions such as banks, in hight of the inagnitude of recent suits against thein. In essence, the wholly-owned captive faces the same D \& $O$ liability risks that prevented the parent from securing coverage in the coininercial market.

Recently, a group of more than thirty of the nation's largest banks created Bankers Insurance Coinpany Limited, a Bermuda-based nutual imsurance company, to cover their directors' and officers' liability and fidehty exposures. ${ }^{110}$ The large number of participants in the new company, each contributing a sizeable anount to its capitalization, has enabled Bankers Insurance to spread risks sufficiently to attract adequate reinsurance. ${ }^{11}$ Moreover, because an industry captive has multiple owners, and generally insures nonowners as well, it sidesteps sonie of the selfindemnification, bankruptcy, and tax benefit drawbacks of single-coin-

107. A majority of the states possess enabling statutes. See, e.g., DEL. CODE ANN. tit. 8, $\S 145(\mathrm{~g})$ (1983); CAL. CORP. CODE $§ 317$ (i) (West 1977); REviSEd MODEL Bus. CoRP. ACT $\S 8.57$ (1986 supp.). A full list of these statutes can be found in Greenburg \& Dean, supra note 52, at 566 n.46. Minnesota, which had been the only state to prohibit corporations by statute from purchasing $D \& O$ coverage broader than their powers of indemnification, in 1981 replaced that statute with one allowing such coverage. MiNN. STAT. ANN. § 302A.521(7) (West 1985) (effective July 1, 1981). New York, at the same time, scrapped its liberal statute in favor of one considerably more restrictive (N.Y. BuS. CoRP. LAW $\S 727(a)(3)$ (McKinney 1986). Even in those states without specific enabling statutes, it is generally assumed that corporations may purchase broad $D \& O$ insurance. See generally Oesterle, supra note 105, at 549-52.

108. Rev. Rul. 69-491, 1969-2 C.B. 22 allows a corporation to deduct $D$ \& $O$ insurance premiums as an ordinary business expense. Insurance premiums paid to wholly-owned subsidiaries, however, have been declared nondeductible. See, e.g., Stearns-Roger Corp. v. United States, 577 F. Supp. 833 (D. Colo. 1984), aff'd 774 F.2d 414 (10th Cir. 1985); Carnation Co. v. Commissioner, 71 T.C. 400 (1978), aff'd, 640 F.2d 1010 (9th Cir.), cert. denied 454 U.S. 965 (1981). But cf. Crawford Fitting Co. v. United States, 606 F. Supp. 136 (N.D. Ohio 1985) (deduction allowed for premiums paid to captive insurer, where taxpayer's direct ownership of captive deemed questionable).

109. Brenner, supra note 104; cf. Adams, ABA: Many States Frown on Captive Insurers, Am. Banker, March 3, 1986, at 12, col. 1. (About half of 35 states polled have laws discouraging or prohibiting banks' investment in a stock company, effectively preventing the formation of a stock captive insurer.).

110. Brenner, Banks' Offshore Self-Insurance Firm Finds Reinsurance, Am. Banker, Nov. 27, 1985, at 1, col. 2 .

111. Id. 
pany captives. ${ }^{112}$

Financial institutions are not the only players in this type of risk pooling. Insurance brokers Marsh \& McLennan recently organized a Cayman Islands insurance pool, the American Casualty Excess Insurance Company Ltd., to which some thirty-four major U.S. industrial, utility, and financial companies have contributed or committed. ${ }^{113}$ Sixtyfive U.S. electric utilities recently formed an offshore captive insurer in Barbados to underwrite D \& O, general liability, and environmental insurance. ${ }^{114}$ Wall Street securities firms also are contenplating forming an industry-owned insurance coinpany to provide liability coverage for brokerage houses. ${ }^{115}$

Another approach that several corporations are considering is the use of an irrevocable letter of credit or a trust deposit to induce reluctant insurers to issue D \& O coverage. Under this approach, a commercial insurer writes standard D \& $O$ liability coverage, but the corporation agrees to repay the insurer all or part of the payments that the insurer makes to directors and officers under the policy. ${ }^{116}$ That obligation is backed by eitler a letter of credit or a trust deposit collateralizing the policy limits. ${ }^{17}$ This approach, however, raises many of the same questions as the self-insurance or captive-insurer approacli since tlie corporation effectively assumes all or most of the insurance risk.

112. Another industry captive has been created by 45 regional bank holding companies. Referred to as the Regional Bank Insurance Project, the Bermuda-based stock corporation will write both D \& $\mathrm{O}$ and blanket bond policies for its members. Rovner, Banks Win Approval to Form Captives For Insurance, Legal Times, Mar. 3, 1986, at 1, col. 3. The Federal Reserve Board officially has approved bank industry captives, provided that no single institution controls more than five percent of the venture. $I d$.

State banking associations, too, view the idea of a captive insurance agency as a welcome alternative to rising premiums and frequent policy cancellations. BancInsure, set up by a consortium of banking associates from Minnesota, North Dakota, South Dakota, Wisconsin, and Oklahoma, provides member banks a range of insurance coverage, including $\mathrm{D} \& \mathrm{O}$ liability. Five Midwest Banking Groups Set Up Insurance Agency for Member Banks, 44 WASH. FIN. REP. (BNA), 1042 (June 17, 1985); see also Rovner, supra note 112, at 4, col. 4. Within weeks of its opening, more than 735 banks had signed letters of intent to participate. See generally Brenner, Banks Create Chcaper Insurer; Oklahoma City Firm Will Sell to State Trade Groups' Members, Am. Banker, July 22,1985 , at 1 , col. 3 .

113. Hilder, Two Insurance Brokers Seek Syndicate to Offer Big Firms Liability Coverage, Wall St. J., Mar. 11, 1986, at 25, col. 1. The venture is owned by its charter participants, including Ford, U.S. Steel, General Electric, IBM, Shell Oil, and Chase Manhattan Bank. Schauer, supra note 16, at 3. In addition to writing excess general liability coverage, A.C.E. will write D \& O coverage of $\$ 50$ million in excess of the first $\$ 25$ million. Id. A.C.E. is expected to issue policies to between 200 and 300 companies by the end of 1986 . Hilder, supra.

114. Light, Insurance Captive Formed, Am. Banker, April 15, 1986, at 3, col. 1.

115. Securities Firms to Weigh Starting Insurance Concern, Wall St. J., Mar. 20, 1986, at 2, col. 3.

116. Schauer, Address to Section Council Meeting of ABA Section on Corporation, Banking and Business Law (Jan. 19, 1986).

117. Id. 


\section{c. Stopgap Measures and the "Laundry List"}

The $\mathrm{D} \& \mathrm{O}$ insurance crunch has set corporations scrambling for alternative means to close the gaps in liability protection for their key executives. Many firms are reviewing and rewriting their bylaws and articles of incorporation, either to broaden the perimeters within which they can indemnify their directors and officers ${ }^{118}$ or to place ceilings on each director's inaximum personal liabilty for duty of care violations. ${ }^{119}$ Other corporations are considering reincorporating in states witl better statutory indemnification allowances. ${ }^{120}$

Another measure taken by some firms has been to offer their directors and officers individual indemnification contracts. ${ }^{121}$ While these contracts cannot confer any protection not already allowable under state law, they can function as a legal backup for mdividual directors should future boards of directors tamper with existing $D$ \& O coverage or modify the indemnification provisions of the bylaws. ${ }^{122}$ Still other firms have established irrevocable trusts or have obtained irrevocable letters of credit im favor of their directors and officers to ensure indemnification of those executives' litigation expenses. ${ }^{123}$ Despite the "coinforting" aspects of these and other measures, however, experts are quick to point out that they are inadequate substitutes for traditional $\mathrm{D}$ \& $\mathrm{O}$ insurance. ${ }^{124}$

Soine compamies, when informed of their D \& O insurer's intent to cancel coverage, liave resorted to an imovative, if somewhat desperate,

118. See M. SCHAEFTLER, supra note 30 , at $121-45$ (discussing strengths and weaknesses of indemnification provisions in bylaws); Olson, The $D \& O$ Insurance Gap: Strategies for Coping, Legal Times, Mar. 3, 1986, at 25, col. 1 (providing a charter- documents review checklist for possible expansion of statutory indemnification rights).

119. See Futter \& Gross, Charter Amendment Offers Way Out of $D \& O$ Crisis, Legal Times, June 9,1986 , at 11 , col. 1 .

120. Herzel \& Harris, supra note 102 (Indiana is one such state).

121. See Rovner, $D \& O$ Indemnity; Discrete Contracts Seen as an Option, Legal Times, Nov. 25, 1985, at 1, col. 3; see also M. SCHAEFTLER, supra note 30, at 145-46 (discussing pros and cons of indemnification contracts); Olson, supra note 118, at 33, col. 1.

122. Rovner, supra note 121, at 2, col. 2; see also Mooney v. Willys-Overland Motors, Inc., 204 F.2d 888 (3d Cir. 1953) (suggesting that supplemental indemnification contracts are enforceablc under Delaware law).

123. See Olsen \& Morgan, supra note 92, at 34, col. 4; Security Am. Corp. v. Walsh, Case, Coale, Brown \& Burke, No. 82 C 2953, slip op. (N.D. Ill. Jan. 11, 1985) (\$200,000 irrevocable trust, representing approximately one-third of the corporation's assets, held enforceable under Delaware law) (LEXIS Genfed library, Dist file).

124. Rovner, supra note 121 , at 2 . First, unlike insurance, indemnification contracts can confer protection only to the extent of corporate assets. Second, while D \& $O$ insurance may cover judgments and settlements in certain securities-fraud and negligence actions, the Securities Exchange Commission rules and many state statutes prohibit corporate indemnification of those amounts in derivative suits. Finally, the dearth of cases interpreting these contracts renders the likelihood and extent of their enforcement speculative. See id; see also Brenner, Some See Flaws it Alternatives to Directors' and Officers' Liability, Am. Banker, May 16, 1986, at 14, col. 1. 
measure to squeeze as much $D \& O$ coverage as possible out of their existing policy. Almost every $\mathrm{D} \& \mathrm{O}$ policy contains a provision stating that if an insured reports to its insurer, prior to the policy expiration date, any occurrence which indicates the potential for a claim, the insurer will provide coverage even if an actual claim has not been asserted against the insured before the policy expires. ${ }^{125}$ Capitalizing on this provision, nimble companies have fashioned what is now referred to within the insurance industry as a "laundry list"-an expansive list inaking reference to every conceivable act, error, or omission known to the insured which could give rise to a claim in the future. Presented to the insurer just prior to the expiration of the policy, the laundry list is intended to preserve forever coverage of any actual claims arising from histed occurrences. ${ }^{126}$

Use of a laundry hist, however, is not unproblematic for the insureds. First, although many corporate counsel advise their chents to consider developing such hists before pohicies are cancelled, ${ }^{127}$ the hist benefits the insured only if tendered to the insurer after receipt of notice of cancellation or nonrenewal; tendering it prior to that time would almost certainly precipitate cancellation. ${ }^{128}$ Second, the laundry list may be used by a subsequent $\mathrm{D} \& \mathrm{O}$ carrier as a basis for substantial exclusions from cov-

125. The pertinent portion of the provision in the National Union D \& O policy is as follows:

If during the policy period ... the Insureds shall become aware of any occurrence which may subsequently give rise to a claim being made against the Insureds . . . and shall ... during such period give written notice to the Insurer of . . . such occurrence . . . then any claim which may subsequently be made against the Insureds arising out of such [occurrences] ... shall ... be treated as a claim made during the currency hereof.

See M. SChAEFTLER, supra note 30, at 283. The provision is intended to provide some relief against "claims made" policies, which traditionally only covered claims actually asserted against the insured during the policy period. Courts in California and other jurisdictions strongly disfavor such claimsmade limitations and often refuse to enforce them on reasonable expectations and unconscionability grounds. See, e.g., Gyler v. Mission Ins. Co., 10 Cal.3d 216, 219, 514 P.2d 1219, 1221, 110 Cal. Rptr. 139, 141 (1973) ("claims made" clause in legal liability policy construed to require indemnity "for claims maturing during the policy period whether or not the claim is actually asserted during that period").

126. The most exhaustive of these lists often resembles a condensed version of the corporate minutes, chronicling virtually every act-including personnel decisions, asset purchases and sales, stock and dividend distributions, joint venture transactions, etc.-undertaken during the policy period. Such comprehensiveness may be indicative not so much of bad faith on the part of the insureds as it is of the true unpredictability of lawsuits stemming from corporate acts. See infra notes 250-64 and aceompanying text.

127. Interview with Thomas W. Johnson, Jr., Irell \& Manella, in Newport Beach, California (Nov. 17, 1985).

128. See infra note 319 and accompanying text.

Also, inasmuch as some $D$ \& $O$ policies request that notice of potential claims be given the insurer "as soon as is practicable," preparing but then sitting on such a list until it is needed may violate the insured's duty of good faith and fair dealing. See, e.g., Ashley v. American Mutual Liability Ins. Co., 167 F. Supp. 125, 129, 130 (N.D. Cal. 1958) (common law duty of utmost good faith to disclose material facts to insurer). 
erage. ${ }^{129}$ Moreover, if the old carrier successfully denies coverage of laundry hist recitals on the ground that they are too vague or general to constitute reported claims, the insured will be left with sizable gaps in protection. ${ }^{130}$ Finally, any occurrence recited in the list which predates the policy period might provide the insurer grounds to declare the policy void $a b$ initio, if it can prove that an insured knew of but did not disclose the occurrence on the policy application. ${ }^{131}$

\section{Upon Claim Resolution: More Disputes}

The only predictable result of the recent flood of litigation against both corporate executives and $D \& O$ carriers is that neither camp is willing to absorb the staggering losses. Consequently, the last six years have witnessed increasingly volatile interplay between corporations intent on tranferring their losses to their insurers and insurers intent on ininimizing the extent of their duty to insure. ${ }^{132}$ In a number of recent legal embroilments, the theories of noncoverage posited by the insurers, if not particularly convincing, have been both innovative and diverse.

129. The new carrier may attempt to attach the list to the applicant's response to the preexisting knowledge clause in the policy application, see infra text accompanying notes 155-56, sinee both the list and that clause involve disclosing acts, errors, or omissions which a director or officer believes might give rise to an insurable claim.

130. A compromise might be achieved whereby the new carrier issues a linited exclusion barring only those claims for which indeınnity is paid by the prior carrier. It is certainly in the interest of the new insurer for the corporation to provide the prior insurer with the most complete laundry list possible.

131. This Comment analyzes and evaluates insurers' attempts to avoid D \& O coverage on this ground. See infra notes 160-248 and accompanying text.

132. See, e.g., National Union Firc Ins. Co. v. Continental Illinois Corp., Nos. 85-C-7080, 85-C7081 (N.D. Ill. filed Nov. 14, 1985), in which three insurers (National Union, Allstate, and Harbor Ins. Cos.) responded to news of a shareholders' class action against Continental Illinois National Bank by suing to rescind its D \& O coverage. Continental Illinois promptly counterclained against each insurer, charging inter alia that National Union has "over the last few years engaged in a pattern and practice of filing rescission actions, without regard to the inerits of those actions, whenever it is faced with the possibility of a significant claim on a $[D \&$ O policy." Continental Illinois Sues 3 Insurers for not Paying on Officers' Policies, 45 WASH. FIN. REP. (BNA) 799 (Nov. 25, 1985). The stakes are enormous: the class action suit recently was settled for $\$ 45$ million, of which $\$ 20$ million is to be paid out of the bank's D \& O policy. The settlement agreement allows the FDIC-which took over the bank after its near-collapse in 1984-to receive further damages ranging from $\$ 68$ to $\$ 88$ million from the bank's D \& O insurers. The D \& O policy that the insurers hope to avoid has a $\$ 100$ million limit. Bailey, Continental Illinois Agrees to Settle Suit by Holders, Wall St. J., April 4, 1986, at 6, col. 5; Weiner, Continental Illinois Holders May Get $\$ 49$ Million in Settlement, Am. Banker, April 30, 1986, at 24, col. 1; see infra note 162.

Neither were the insurers of Manville forthcoming as to the claims of thousands of workers who had contracted mesothelioma and other asbestos-related diseases. In August, 1982, when Manville filed for Chapter 11 protection from its creditors, it also filed a $\$ 5$ billion claim for punitive damages against more than two dozen insurance companies, including Home Insuranee, Travellers, Commercial Union, and Aetna. See Lewin, Insurers Balking on Company Losses, N.Y. Tiines, Mar. 30, 1983, at 1, col. 1; see also Unocal Corp. v. Harbor Ins. Co., No. C550393 (Cal. Super. Ct., Los Angeles, June 4, 1985) (complainant charged that its former D \& $O$ insurers liad formed "the secret and undisclosed intent to issue a Notice of Cancellation . . . at the first sign of a hostile takeover 
For example, in Okada v. MGIC Indemnity Corp., ${ }^{133}$ the D \& O insurer attempted to characterize numerous independent claims by the insured savings institution as "one loss," so as to invoke its $\$ 1$ million per loss ceiling; the court rejected the argument. ${ }^{134}$ The insurer also denied any obligation to reimburse its corporate insureds for attorneys' fees as they were billed as well as any duty to enter imto settlement negotiations at its insured's request. ${ }^{135}$ The court enforced both obligations and further found that the insurer had breached its covenant of good faith and fair dealing. ${ }^{136}$

In Walsh v. Employer's Insurance of Wausau, ${ }^{137}$ the insurer claimed that the FDIC, which as receiver of a failed bank was sumg seventeen former directors and officers, had no standing to seek a judgment against the insurer declaring that the individual directors and officers had D \& $O$ coverage. The court agreed with the insurer's theory that the FDIC had no stake in that part of the policy assigning coverage to the individual directors and officers. As successor to the bank, the FDIC's only clain against the insurer would be under that part of the pohicy covering the bank. However, the court went on to rule that the FDIC's additional role as plamtiff in the inain case agamst the directors and officers gave it a direct interest in the declaratory determination of their $\mathrm{D} \& \mathrm{O}$ coverage, since if the FDIC prevailed in the main case it would be paid out of that insurance. Consequently, the insurer's inotion to deny the FDIC standing was refused. ${ }^{138}$

attempt or of any other major event likely to give rise to a claim." Victor, $D \& O$ Cancelled and Unocal Sues, Legal Times, July 29, 1985, at 1, col. 2).

One enterprising underwriter-Professional Indemnity Agency Inc.-has responded to this upsurge in coverage disputes by offering an insurance policy to cover the legal expenses of suing an insurer who refuses to pay out a claim. See Lewin, supra.

133. 608 F. Supp. 383 (D. Haw. 1985), aff'd in part, rev'd in part, 795 F.2d 1450 (9th Cir. 1986).

134. Id. at 388 .

135. Id, at 390 .

136. Id. On appeal, the Ninth Circuit affirmed on all issues except the summary judgment ruling that MGIC had acted in bad faith. 795 F.2d at 1457.

North River Insurance Company v. Huff, No. 84-2069-S, slip op. (D. Kan. Nov. 20, 1985) (LEXIS, Genfed library, Dist file), closely followed the result in Okada. In a declaratory judgment action, the court rebuffed the insurer's attempt to limit its coverage of a failed savings institution's directors and officers sued by the FSLIC for loan mismanagement. The court held that four independent "loan swap" transactions, although similar in method, constituted separate "occurrences" under the $\mathrm{D} \& \mathrm{O}$ policy. Id. The insurer also sought to deny reimbursement to its insureds of the attorneys' fees they incurred defending the action to limit coverage. The court again disagreed, holding that the insurer's promise under the policy to "pay the insureds for all reasonable expenses ... incurred at the [insurance] company's request" included those spent defending declaratory judgment actions brought by the insurer. Id.

137. No. 85 C 1770 (consolidated with No. 84 C 10029), slip op. (N.D. Ill. Nov. 8, 1985) (LEXIS, Genfed library, Dist. file).

138. Id. For a more recent example of the court's refusal to dismiss a suit by the FDIC against a failed bank's $\mathrm{D} \&$ O insurer, see Federal Deposit Insurance Corp. v. National Union Fire Ins. Co., 
In Continental Casualty Co. v. Board of Education, ${ }^{139}$ the insurer refused full reimbursement of its imsured's attorneys' fees and expenses, on the ground that a portion of the suit against the insured alleged claims that were not covered by the insurance policy. Although the court approved the idea of apportioning expenses between covered and noncovered claims, it defined expenses "reasonably related" to covered claims so broadly that all of the insured's expenses were included. ${ }^{140}$

In Continental Copper \& Steel Industries, Inc. v. Johnson, ${ }^{141}$ the insurer unsuccessfully argued that the wrongful acts of the directors claiming coverage were coinnitted in their capacity as directors of an uninsured corporation to which the directors had been assigned by the insured corporation. Since the wrongful acts were performed for the benefit of the insured corporation, however, the court reasoned that coverage nuust be provided. ${ }^{142}$

In KDT Industries, Inc. $v$. Home Insurance Co., ${ }^{143}$ the insurer attenipted to characterize a special policy endorsenient excluding coverage of sharelolder actions stemming from takeover or acquisition atteinpts as excluding coverage of all minority shareholder actions. Here again, the court lield the coverage was not excluded. ${ }^{144}$

In American Casualty Co. v. Community Savings \& Loan, Inc., ${ }^{145}$ the court stymied the insurer's attempt to rescind or reform a saving and loan association's D \& O policy. The court lield that since the Maryland Deposit Insurance Fund ("MDIF") then in receivership of the association enjoyed eleventl amendinent imniunity from suit, and since the MDIF was an necessary party to the insurer's action, the action inust be dismissed as to all defendants. ${ }^{146}$

One explanation for the number and variety of disputes involving $D$ $\& O$ hability coverage is the vague and ambiguous wording of many of

630 F. Supp. 1149 (W.D. La. 1986) (FDIC as successor to bank not barred under insider-suit exclusion in D \& $O$ policy from suing bank's directors and officers); see also supra note 87.

139. 302 Md. 516, 489 A.2d 536 (1985).

140. Id. at 537-38, 489 A.2d at 546-47.

141. 491 F. Supp. 360 (S.D.N.Y. 1980), aff'd, 641 F.2d 59 (2d Cir. 1981).

142. Id. at 363 .

143. 603 F. Supp. 861 (D. Mass. 1985).

144. Id. at 868 .

145. 635 F. Supp. 539 (D. Md. 1986).

146. Id. at 543 .

Even prior to the 1980 's the courts were less than receptive to insurers' attempts to dodge coverage under D \& O policies. In FDIC v. MGIC Indemnity Corp., 462 F. Supp. 759 (E.D. Wis. 1978), the court rejected the insurer's argument that it could not be named as a defendant by the party suing its insured until the liability of its insured first had been established. And in Flintkote Co. v. Lloyd's Underwriters, N.Y.L.J., July 27, 1976, at 6, col. 3, aff'd, 56 A.D.2d 743, 391 N.Y.S.2d 1005 (1977), the court held that the insured director's plea of "nolo contendere" to criminal price-fixing charges did not excuse Lloyd's from coverage under the criminal act exclusion of its policy. Flintkote is discussed in detail in Johnston, supra note 1, at 2028-29. 
the D \& O policy provisions. ${ }^{147}$ Perhaps part of the motivation behind the courts' relatively consistent rejection of $D$ \& $O$ insurers' atteinpts to circumscribe coverage is the desire not to reward the insurers' lack of precision in drafting the policy. ${ }^{148}$

Underwriters have had at least some success against their insureds on one particular theory of noncoverage, however. Rather than argue exclusions to coverage, some underwriters assert that the entire $D$ \& $O$ pohicy is void $a b$ initio due to the insured's alleged misrepresentations on the policy apphication. Although the few cases that have adjudicated this issue have reached different conclusions as to the merits and doctrinal underpinnings of such a refusal, one thing is certain: the $D \& O$ policy application as written leaves the door wide open for further disputes in this area.

\section{II \\ DyNAMICS OF THE APPLICATION MISREPRESENTATION DISPUTE}

\section{A. The Application Clauses}

The typical $\mathrm{D} \& \mathrm{O}$ policy consists of two parts. The first provides reimbursement to the corporation for indemnification payments inade to insured directors or officers. The second provides personal coverage directly to the directors and officers should the corporation be unable or unwilling to indemnify them. Claims made directly agamst the corporation generally are not covered. ${ }^{149}$

Most D \& O policies operate on a "claims made" basis, meaming that regardless of the date of the original occurrence giving rise to the lawsuit against the insured, only claims filed with the insurer during the policy period will be covered. Most policies, however, permit the insured to extend coverage for a limited period upon payment of additional pre-

147. See, eg., Bishop, supra note 3, at 21 ("Some [D \& O policy] clauses have all the obscurity that has long typified insurance contracts and some clauses have obscurity all their own."); see also infra text accompanying notes 254-99.

148. See Bishop, New Cure for an Old Ailment: Insurance Against Directors' and Officers' Liability, 22 Bus. LAw. 92 (1966).

149. See Johnston, supra note 1, at 2013.

The majority of $\mathrm{D} \& \mathrm{O}$ policies technically are considered reimbursement policies, as opposed to general liability policies. The essence of the distinction is that with reimbursement policies the insureds must first pay any awards, settlements and defense costs, and then be reimbursed by the insurer. Id. at 2016. See generally Comment, supra note 18, at 691-92, 709-12. Unlike most liability insurance, $D$ \& $O$ policies generally do not require the insurer to take over or otherwise manage the defense of the claim. See WyatT Policy ANAlysis, supra note 85, at 20-21. But see Okada v. MGIC Indemnity Corp., 608 F. Supp. 383 (D. Hawaii 1985) (court construed "loss" in D \& O policy to include interim defense costs on ground that reasonable expectation of insured requires interim reimbursement given the exceptional length and cost of most lawsuits). 
mium $^{150}$ or allow for coverage of claims made after the policy period, if the insured notifies the insurer of the occurrence that gave rise to the claim before the policy expires. ${ }^{151}$

A number of thoughtful articles explain the function and general mechanics of the $\mathrm{D} \& \mathrm{O}$ policy, and a thorough explication here is unwarranted. ${ }^{152}$ This Comment instead will focus on a discrete coinponent of the policy form: the application. ${ }^{153}$

The application form typically is filled out by an officer of the corporation seeking insurance for itself and its officials. ${ }^{154}$ The application serves as the basis for granting $\mathrm{D} \& \mathrm{O}$ coverage and is incorporated into the policy. ${ }^{155}$

The application invariably requests that the potential insured provide detailed information to assist the insurer in evaluating the underwriting risk. Usually this request takes the form of detailed interrogatories asking for, among other things, a list of all directors and officers, subsidiaries, annual sales, net worth and total assets, number of shares and shareholders, any pending litigation involving the firm, and copies of the latest annual report, bylaws-indemnification provisions, and any S.E.C. statements filed. ${ }^{156}$

Following these interrogatories, the application poses the following question:

Does any Director or Officer have knowledge or information of any

150. See Wyatt Policy ANAlysis, supra note 85 , at 8.

151. See id. at 7; supra notes 125-31 and accompanying text.

152. See, e.g., W. KNEPPER, LIABLITY OF CORPORATE OFFICERS AND DiRECTORS 429-64 (2d ed. 1973 \& Supp. 1976); M. SCHAEFTLER, supra note 30; WYATT Policy ANALYsIS, supra note 85; Bishop, supra note 148; Bishop, supra note 30; Bishop, supra note 3; Greenburg \& Dean, supra note 52, at 568-81; Hinsey, The New Lloyd's Policy Form For Directors and Officers Liability InsuranceAn Analysis, 33 Bus. LAw. 1961; Johnston, supra note 1, at 2012-23; Comment, supra note 18, at 699-712.

153. For simplicity's sake, this Comment will analyze application clauses from one $D \& O$ insurance policy, that of National Union Fire Insurance Company of Pittsburgh, Pennsylvania. National Union and American Home Assurance Co. are trade names of American International Group (AIG) which, with more than one-fifth of all U.S. primary accounts and one-fourth of U.S. excess accounts, is the largest D \& O insurance underwriter in the U.S. and Canada. 1985 WYATT REPORT, supra note 69, at 25.

A copy of the entire application form and policy of National Union Fire Insurance Company can be found in M. SCHAEFTLER, supra note 30, at 275-76.

No standardized industry form exists for the $D \& O$ policy, resulting in substantial differences in policy language and provisions among various underwriters. Nevertheless, each of the policy forms surveyed employs in its application a preexisting knowledge clause. See infra notes 157-58 and accompanying text. The wording of each of these clauses is similar. See WYATT PoLICY ANALYSIS, supra note 85 , at 22-23. Consequently, the criticisms of that clause presented in this Comment are equally applicable to other $\mathrm{D} \& \mathrm{O}$ insurance application forms.

154. Most insurers now require that the application be signed by either the Chairman of the Board or the President. WyATT POLICY ANALYSIS, supra note 85, at 23.

155. See M. SCHAEFTLER, supra note 30 , at 167 .

156. See id. at 275-76. 
act, error, or omission which might give rise to a claim under the proposed policy? ${ }^{157}$

This Comment shall refer to this provision as the "preexisting knowledge clause." 158 Shortly after this clause the application states: "It is agreed that if such knowledge or information exists any claim or action arising therefrom is excluded from this proposed coverage." 159 This Comment shall refer to this provision as the "exclusion clause."

The preexisting knowledge clause, and its operation with the exclusion clause, have in recent years served as the basis for a number of attempts by $D \& O$ insurers to avoid coverage of claims. If a court later determines that an insured knew of an event that might have given rise to a claim, the pohicy applicant's negative response to the preexisting knowledge clause could enable the insurer to refuse coverage of the claim or declare the policy void $a b$ initio. The courts have reached no consensus as to low the preexisting knowledge clause and the applicant's response to it sliould be interpreted, however, resulting in inconsistent resolution of coverage disputes.

\section{B. The Cases: A State of Disarray}

As of April 1986, five disputes addressing the interpretation and operation of the preexisting knowledge clause had been litigated and at least partially adjudicated; ${ }^{160}$ a number of other disputes in which $D \& O$

157. Id. at 275. For comparison's sake, the question posed in St. Paul Fire and Marine Insurance Company's D \& $O$ Application form is as follows:

18. (b) Has any director or officer any knowledge or information of any negligent act, error, omission or breach of duty which might give rise to a claim against him? Id at 290.

The Home Insurance Company poses the following question:

13. Is the undersigned or any Director or Officer proposed for insurance aware of any fact, circumstance or situation involviug the Company, its Subsidiaries or the Directors or Officers of the Company or its Subsidiaries which he has reason to suppose might result in any future claim such as would fall within the scope of the proposed insurance?

Practising Law Inst., The Developing Law of Business Errors and OMISSions InsurANCE 142 (D. Yeager ed. 1983).

Lloyd's of London, circa 1970, employed the following:

No person proposed for this insurance is cognizant of any act, error, or omission which he has reason to suppose might afford valid grounds for any future claim such as would fall within the scope of the proposed insurance except as follows:

Bird v. Penn Central Co., 334 F. Supp. 255, 257 (E.D. Pa. 1971).

158. The WyatT Policy ANALYSIS, supra note 85 , at 22, refers to these provisions as " 'Cognizant' Statements."

159. M. SCHAEFTLER, supra note 30 , at 276.

160. Shapiro v. American Home Assurance Co., 584 F. Supp. 1245 (D. Mass. 1984); Automotive Wholesalers v. National Union Fire Ins. Co., 501 F. Supp. 1205 (N.D. Ill. 1980); Zaremba v. National Union Fire Ins. Co., 1979 Fire \& Casualty Cas. (CCF) 1302 (N.D. Ohio 1978); Bird v. Penn Central Co., 334 F. Supp. 255 (E.D. Pa. 1971), motions denied on rehearing, 341 F. Supp. 291 (E.D. Pa. 1972); Amrep Corp. v. American Home Assurance Co., 81 A.D.2d 325, 440 N.Y.S.2d 244 (1981). 
application misrepresentation cliarges played a role liad been settled. ${ }^{161}$ More disputes, liowever, lie on the horizon. ${ }^{162}$

In most of the reported cases, the insurer did not discover that the applicant's response to the preexisting knowledge clause was erroneous until after the litigation underlying the reimburseinent clain was well underway. ${ }^{163}$ In some cases the officer or director who coinpleted the D \& $O$ policy application was the same one who possessed preexisting knowledge of the act, error or omission which gave rise to the clain. ${ }^{164}$ In one case an officer or director otlier than the applicant possessed such knowledge. ${ }^{165}$ Even these factual differences, however, cannot account for the courts' disparate and incomplete treatinent of the issues raised by the preexisting knowledge clause.

For example, most courts liave focused some attention on whether the misrepresentation or ignorance of one insured director or officer slould affect the coverage of the other insureds. But even where different courts have concluded that due to the material misrepresentation of one insured the entire $\mathrm{D} \& \mathrm{O}$ policy was void ab initio, no two courts have yet agreed as to the theory upon which that conclusion should rest. One court relied upon the agency relationship binding togetler all the directors and officers, liolding that the knowledge of one sliould be imputed to all. ${ }^{166}$ Anotlier court rejected the agency theory, yet declared the D \& O

161. See, e.g., Shlensky v. Dorsey, 574 F.2d 131, 138, 148 n.11 (3d Cir. 1978); American Employers' Ins. Co. v. King Resources Co., 556 F.2d 471, 475 (10th Cir. 1977); In re THC Financial Corp. Litigation, 86 F.R.D. 721, 731-35 (D. Haw. 1980) (describing the settlement of suits between directors and officers of The Hawaii Corporation and Continental Casualty Co., in which the D \& $O$ insurer had charged that the D \& O policy was fraudulently procured). When the directors of Gulf Oil settled a sizeable "questionable payments" claim, its D \& $O$ insurer at first refused reimbursement on the ground of application fraud, and ultimately contributed only $\$ 2$ million-less then $10 \%$ of the policy limit. Bishop, supra note 3, at 21; see also WYATT POLICY ANALYS1S, supra note 85 , at 22 ("There have been many settlements where recovery from the Insurer was reduced based on the breach of warranty argument.").

162. See, e.g., National Union Fire Ins. Co. v. Continental Ill. Corp., No. 85-C-7080 (N.D. Ill. filed August 14, 1985). Three insurers have alleged that in applying for an increase in D \& $O$ insurance in 1981 from $\$ 40$ to $\$ 100$ million, the defendants, who include 32 officers and directors, "falsely and fraudulently misrepresented the facts with respect to Continental's perilous financial condition." Continental Illinois Sues 3 Insurers for not Paying on Officers' Policies, supra note 132. In the aftermath of the bank's near collapse in 1984 and its recent settlement of a class action shareholder suit, total claims for reimbursement under the D \& O policy are expected to cxceed its $\$ 100$ million limit. See supra note 132.

National Union Fire Ins. Co. has also sued to rescind the D \& O coverage of the United American Bank of Knoxville pursuant to that bank's collapse in February, 1983. See Am. Bankcr, supra note 68 , at 16.

163. See Shapiro, 584 F. Supp. 1245; Zaremba, 1979 Fire \& Casualty Cas. (CCH) 1302; Bird, 334 F. Supp. 255; Amrep, 81 A.D.2d 325, 440 N.Y.S.2d 244. But see Automative Wholesalers, 501 F. Supp. 1205.

164. See Shapiro, 584 F. Supp. at 1248; Automotive Wholesalers, 501 F. Supp. at 1209; Bird, 334

F. Supp. at 257.

165. See Zaremba, 1979 Fire \& Casualty Cases (CCH) at 1304.

166. Bird, 341 F. Supp. at 295. 
policy void $a b$ initio on an intent-of-the-parties rationale. ${ }^{167}$ Still a third acknowledged a limited agency relationship existing between officerapplicant and corporation but not between officers; since the applicant was not the same officer possessing the preexisting knowledge, coverage under the policy was not denied to him or the other innocent insureds. ${ }^{168}$

Further disagreement among the opinions concerns whether to characterize the applicant's response to the preexisting knowledge clause as a warranty of fact or a representation of good faith belief. ${ }^{169}$ Finally, the courts have been unable to decide whether the exclusion clause should operate as an objective condition precedent to coverage or sliould remam tied to the subjective standard of breach of the preexisting knowledge clause. ${ }^{170}$

The courts' failure to address other issues central to proper interpretation of the preexisting knowledge clause has aggravated the problem. These issues include the inherent vagueness in the scope of the clause's request for information, ${ }^{171}$ anbiguities within the terminology of the clause, ${ }^{172}$ uncertainty about the applicant's duty of inquiry regarding the other insureds, ${ }^{173}$ and the potentially unconscionable effects of the preexisting knowledge clause operating in tandein with the exclusion clause. ${ }^{174}$

The following review of the cases reported to date illustrates the confusion currently surrounding theories of hability for application misrepresentation and the inability of the courts to agree upon a structural framework for adjudication.

\section{Bird v. Penn Central Co. ${ }^{175}$}

Following on the heels of the Penn Central Railroad's ignoininious collapse in 1970, Lloyd's of London and sixteen U.S. underwriters sued to rescind the railroad's D \& O hability coverage. ${ }^{176}$ The D \& O policy, first issued in 1968 , extended $\$ 10$ million in coverage to Penn Central

167. Shapiro, 584 F. Supp. at 1252.

168. Zaremba, 1979 Fire \& Casualty Cas. (CCH) at 1305-06.

169. Compare Zaremba v. National Union Fire Ins. Co., 1979 Fire \& Cas. (CCH) 1302, 1306-07 (N.D. Ohio 1978) (clause held to be representation) with Shapiro v. American Home Assurance Co., 584 F. Supp. 1245 (D. Mass. 1984) (although a representation, clause held effectively to operate as a warranty, see infra note 197).

170. Zaremba, 1979 Fire \& Casuaity Cas. (CCH) at 1306-07.

171. See infra notes $250-64$ and accompanying text.

172. See infra notes $298-99$ and accompanying text.

173. See infra notes $265-67$ and accompanying text.

174. See infra notes $300-40$ and accompanying text.

175. 334 F. Supp. 255 (E.D. Pa. 1971), motions denied in reh'g, 341 F. Supp. 291 (E.D. Pa. 1972).

176. Bird, 334 F. Supp. at 257. Once the insurers realized the magnitude of Penn Central's exposure at the time of its collapse, they undoubtedly wanted no part of the flood of claims against the railroad and its officials which were sure to follow. See, e.g. Timlen, Commercial Paper-Penn Central and Others, in Financial Crises: Institutions and Markets in a Fragile 
and approximately sixty directors and officers. David Bevan, chairman of Penn Central's Finance Committee, had executed the application. ${ }^{177}$ Lloyd's charged that Bevan's negative response to the preexisting knowledge clause- "Item 10" on the application ${ }^{178}$ - was fraudulent because he and other unspecified officers knew of at least three situations capable of giving rise to an insurable claim. ${ }^{179}$ None of those situations had in fact resulted in lawsuits at the time Lloyd's sued. ${ }^{180}$

Three of the named defendants moved for summary judgment, advancing a barrage of arguments against rescission. ${ }^{181}$ Among other things, they argued that the insertion of the exclusion clause in the policy proved that a limited exclusion of coverage, rather than rescission, was the contracted-for remedy for fraudulent responses to Item 10 . If the policy were construed to permit rescission, they contended, the exclusion clause would be "mere surplusage," since upon rescission there would be nothing left to exclude. ${ }^{182}$ The court countered that the exclusion clause was not surplusage since it operated to exclude not only situations fraudulently misrepresented, but also "known situations disclosed in reply to Item 10, as well as innocently misrepresented situations either disclosed or non-disclosed."183 Moreover, the exclusion clause enabled the insurer to avoid discrete claims arising from misrepresentation in cases where it chose not to seek rescission. ${ }^{184}$

The directors next argued that any false response to the preexisting knowledge clause could not be material, simce the facts allegedly omitted were completely unrelated to any actual lawsuits against the railroad. Noting, however, that materiality related "to the risk assumed, not to the loss incurred," the court held that the omitted information would be material if, had it been disclosed, Lloyd's would have altered its estimation of Penn Central's insurability. ${ }^{185}$ Materiahty was held to be a jury

ENvironment 221 (E. Altman \& A. Sametz eds. 1977) (Penn Central possessed more than $\$ 200$ million in outstanding commercial paper alone at the time of its demise).

177. Bird, 334 F. Supp. at 257.

178. See supra note 157.

179. "(1) [T] he alleged investment by Penn Central in Executive Jet Aviation; (2) the alleged conflict of interest of certain directors who were involved in a private venture known as Penphil Corporation; and (3) the alleged illegal activities of Howard Butcher, III, a director of the railroad ..." Bird, 334 F. Supp. at 257.

180. Id. at 259.

181. As a first attack, they asserted that the absence in the application of any specific provision reserving the right to rescind for fraudulent misstatement indicated a waiver of that right because other Lloyd's policies contained such provisions. The court responded, however, that as an equitable common law right rescission requires no express recital in the policy to operate. Id. at 258 .

182. Id. at 258 .

183. Id.

184. Id. An insurer has ample incentive to exclude discrete claims rather than rescind: rescission would require refunding all premiums received under the policy since its inception.

185. Id. at 259 (quoting Shafer v. John Hancock Mut. Life Ins. Co., 410 Pa. 394, 400, 189 A.2d 234,237 (1963)). 
question precluding summary judgment. ${ }^{186}$

Finally, the directors asserted that, even assuming that Lloyd's had the right to rescind, it could not do so against innocent insureds such as themselves. As to them, Bevan's negative response to the preexisting knowledge clause was true and accurate. Moreover, they had neither responded to the application nor authorized Bevan to make any representations on their behalf. ${ }^{187}$ The court rephed that since the individual directors and officers were not parties to the $\mathrm{D} \& \mathrm{O}$ imsurance contract, their guilt or innocence was "irrelevant."188

There is a sufficient basis for finding that the real parties to the contract were plaintiffs and the Penn Central Company. ...

... Construmg tlie policy in this manner ... [t] tors would all be in the position of third party beneficiaries. Their rights as such would depend on the contract, and if it is voidable for fraud as to the contracting party, Penn Central, their rights would rise no higher. ${ }^{189}$

If Bevan's authority to act as agent for Penn Central and his ensuing fraud could be proven at trial, the policy would be rescinded. ${ }^{190}$

Five montlis later, acknowledging "some doubts about whetler our conclusion was correct" if one were to view individual directors and officers as contracting parties to the D \& O pohicy, Chief Judge Lord granted reargument on Penn Central's summary judgment motion. ${ }^{191}$ Based on a closer reading of the policy termmology, lie concluded that the Lloyd's policy indeed consisted of two parts, the company reimbursement portion and the $\mathrm{D} \& \mathrm{O}$ liability portion. The latter portion treated the directors and officers as principal parties, each "a separate promisee under [the] policy." 192

Since Bevan was the only director or officer to execute the application, he did so as agent for each of the others. This settled, the rest of Chief Judge Lord's analysis was easy: Under a "well established doctrine of agency law," since the knowledge of the agent is imputed by law to the principal, any "fraud of the agent in inducing a contract is binding on an

186. Id. at 260. Also surviving summary judgment and deferred until the trial were the defendants' allegations that Lloyd's was estopped from rescinding by having waited too long after receiving notice of the omitted information, and that Lloyd's was unreasonable in believing that Bevan had the capacity, given his position and duties at Penn Central, accurately to answer the preexisting knowledge clause. Id.

187. Id. at 261 .

188. Id.

189. Id.

190. Id. Determined to cover all his bases, Chief Judge Lord then noted that under another "plausible" construction of the policy, each director and officer could be considered a separate principal party to the contract. However, even under this construction, the defendants would still lose since, having just denied Bevan's authority to sign the applieation, they were estopped from trying to affirm the insurance contract as a whole. Id. at 261-62.

191. Bird v. Penn Central Co., 341 F. Supp. 291, 293 (E.D. Pa. 1972).

192. Id. 
innocent principal." 193 Should Bevan's fraud be proven at trial, the entire $\mathrm{D} \& \mathrm{O}$ pohicy would be rescindable.

The court provided the following justification for its holding:

While we . . recognize that innocent officers and directors are likely to suffer if the entire pohicy is voidable because of one man's fraudulent response, it must be recognized that plaintiff imsurers are likewise innocent parties. ...

... Where one of two innocent persons must suffer by the fraud or neghigence of a third, whichever of the two has accredited him ought to bear the loss .... "194

Moreover, considering the "inescapable fact"195 that only one application and one preexisting knowledge clause were einployed for all the insureds, it would be unfair to the insurer to speculate how inuch a different response would have affected its decision to insure.

What the court failed to factor into this "fairness evaluation" was that Lloyd's itself chose to draft and use the single application format responsible for the agency disputes. Consequently, Lloyd's was far froin "innocent" vis-a-vis the defendant directors. In general, the insurer's relative control over pohcy language is a factor weighing against the insurer in adjudicating coverage disputes. ${ }^{196}$

\section{Zareinba v. National Union Fire Insurance Co. ${ }^{197}$}

Zaremba presented the Northern District of Ohio with a $\mathrm{D} \& \mathrm{O}$ policy coverage dispute similar in scope to that in Bird, but with soune interesting factual twists. By 1975, the Northern Ohio Bank ("NOB") was a financial shainbles: bankrupt and in receivership, its directors and officers were being sued in a shareholder class action. To inake inatters worse, National Union, NOB's D \& O insurer, responded to word of the lawsuit by promptly refunding all of NOB's premiuuns paid to date and declaring the $\mathrm{D} \& \mathrm{O}$ policy void $a b$ initio. Several directors and officers thereupon sought a declaratory judgment upholding coverage. ${ }^{198}$

In defense, National Uinon alleged that NOB's negative response to the preexisting knowledge clause was fraudulent. Unlike Bird, the one accused of possessing nondisclosed preexisting knowledge was not the applicant, but a different officer, NOB's President Palnier. Neither Vice

193. Id. at 295.

194. Id. at 294-95 (quoting dictum in Mundorff v. Wickersham, $63 \mathrm{~Pa} .87,89$ (1870)).

195. Bird, 341 F. Supp. at 295.

196. See infra notes $342-44$ and accompanying text. Ultimately, the case was settled for $\$ 12.6$ million. Of this, Lloyd's reputedly contributed \$2.4 million. WYATT Pol.icY ANALYSIS, supra note 85 , at 22.

197. 1979 Fire \& Casualty Cas. (CCH) 1302 (N.D. Ohio 1978).

198. Id. at 1303. 
President Getzendanner, who executed the application, nor any of the other plaintiff-officers knew of potential claims under the policy. National Union nevertheless asserted the saine agency theory that had proved successful in Bird: applicant Getzendanner acted as agent, not only for NOB under the corporate reimbursement portion of the policy, but for each individual director and officer under the $\mathrm{D} \& \mathrm{O}$ liability portion. ${ }^{199}$ Moreover, the imsurer argued:

[Getzendanner's] knowledge as agent included their knowledge as principals; and it is this composite knowledge that was requested.

... [B]ecause at least one of the principals ... knew that the statements were false, agent Getzendanner must be deemed as a matter of law to have known that the application's statements were false. Therefore [his] statements in the application were not true to the best of his knowledge .... ${ }^{200}$

Rather than contest the rather iron-clad rules of agency, the court opted to resurrect the question whether the applicant actually was acting as agent for the individual directors and officers. For this, it looked to the language of the apphication. Noting that the application provided "The undersigued authorized officer of the financial institution declares that to the best of his knowledge the statements set forth herein are true,"201 Judge Thomas concluded that Getzendanner had indeed acted as agent for NOB, but could not have acted as agent for the individual officials. "Had National Union desired to have ... Getzendanner understand that he was acting as agent for the directors and officers, the application should have expressly said so."202 Consequently, Palmer's preexisting knowledge could not be innputed to Getzendanner. ${ }^{203}$

Nevertheless, a problem reinained. Palmer, as president, also was an agent of NOB. Since, nnder strict agency rules, the knowledge of the agent (Palnier) is the knowledge of the principal (NOB), and the knowledge of the principal is the knowledge of the agent (Getzendanner), Getzendanner would end up in the same position as if he were Palnier's agent directly. ${ }^{204}$

The court recognized, however, that there is an exception to the rule of inputation when an agent's acts are adverse to her principal's interests. In such a case, the principal is not bound because it is presumed that the agent will conceal inforination about adverse acts. The court had no difficulty finding that Palmer's activities giving rise to his knowl-

199. Id. at 1304 .

200. Id.

201. Id. (emphasis added).

202. Id. at 1305.

203. Id.

204. Id. 
edge of potential claims were adverse to NOB. ${ }^{205}$ Therefore that knowledge was not imputed to NOB, and "Getzendanner's answer to ... [the preexisting knowledge clause] was true to the best of his knowledge and to the best of NOB's knowledge."206

As a second line of defense, National Union asserted that Getzendanner's good faith belief in the veracity of his responses was irrelevant, since they were not representations but warranties. ${ }^{207}$ To support this characterization, National Union referred to its statement in the pohicy that the application would be "attached and made a part [of]"208 the policy. "The insurer's decision to incorporate the statement in ... the policy generally controls whether the statement is a warranty or a representation." 209

The court, however, refused to identify the statements as warranties. First, it noted that although it creates a presumption, the law does not necessarily require that imcorporated statements be treated as warranties. ${ }^{210}$ Second, it noted that courts generally do not favor warranties in insurance contracts. Accordingly, a misstatement of fact will not render the policy void $a b$ initio unless the policy clearly and unambiguously provides that it will. The court held that the National Union policy did not. ${ }^{211}$

Finally, the court pointed to the exclusion clause following the preexisting knowledge clause as proof that the latter did not require a warranted response. The court reasoned, "Since [by operation of the exclusion clause] any claim was excluded from the proposed coverage 'if such knowledge or imformation exists,' it is evident that National Union did not regard the answer to [the preexisting knowledge clause] as 'literal truth' on which 'the vahdity of the entire contract depends." "212

In essence, the court's reasoning is identical to the argument that Penn Central advanced unsuccessfully in Bird. As Judge Lord indicated in that case, the argument fails to recognize that the exclusion clause can function to give the insurer the choice to enforce the contract while excising particular clainns from coverage; thus it is not rendered surplusage to

205. Id.

206. Id. at $1305-06$.

207. Id at 1306. As to warranties, "a misstatement of fact voids the policy ab initio." Id. (quoting Allstate Ins. Co. v. Boggs, 27 Ohio St. 2d 216, 218-19, 271 N.E.2d 855, 858 (1971)). For a fuller description of the difference between representations and warranties, see infra notes 280-97 and accompanying text.

208. Zaremba, 1979 Fire \& Casualty Cas. (CCH) at 1306.

209. Id. at 1307 (quoting Allstate v. Boggs, 27 Ohio St. 2d 216, 219, 271 N.E.2d 855, 858 (1971)).

210. Zaremba, 1979 Fire \& Casualty Cas. (CCH) at 1307.

211. Id.

212. Id. (quoting Hartford Protection Ins. Co. v. Harner, 2 Ohio St. $2 \mathrm{~d}$ [sic] 452 (1852) (correct citation is 2 Ohio St. 452)). 
construe the preexisting knowledge clause as eliciting a warranty. ${ }^{213}$ Additionally, even if the exclusion clause itself is understood to operate on just those facts actually disclosed in response to the preexisting knowledge clause, the court might still have held that facts not disclosed (either fraudulently or innocently) render the policy void $a b$ initio. As Bird emphasized, the insurer justifiably depends on coinprehensive and objectively accurate information before approving the insurability of its $\mathrm{D} \& \mathrm{O}$ applicant. $^{214}$

\section{Autoinotive Wholesalers v. National Umion Fire Insurance Co. ${ }^{215}$}

The Northern District Court of Illinois in Automotive Wholesalers addressed the issue of whether the insured could recover attorneys' fees it incurred in a suit challenging the reasonableness of its $D \& O$ insurer's denial of coverage. ${ }^{216}$ In this case too the insurer rehed on the insured's response to a preexisting knowledge clause to disavow coverage. It is the first case to raise the issue of the inherent vagueness of such a clause. The case also illustrates the opportunity for an insurer to use facts obtained froin a D \& O claim as a basis for alleging application fraud.

In October, 1975, three inonths after National Uinon issued a threeyear D \& O pohicy to Autoinotive Wholesalers of Illinois ("AWOI"), the "not-for-profit" trade association notified its insurer of a potential claim under the policy. AWOI had anticipated suits against one of its ineinbers by investors in a recently failed corporation that was controlled in part by AWOI's director, Harry Belliner. ${ }^{217}$ Two inonths later, National Umion declared AWOI's D \& $\mathrm{O}$ policy void $a b$ initio and refunded AWOI's preiniuins. National Union claimed rescission based on the large discrepancy between the amount of AWOI's assets listed on the D \& $O$ apphication and the amount histed in its 1974 financial report. ${ }^{218}$ AWOI refused the preiniuin refund, countering that its application was technically correct and that the insurer was "attenipting to thrust upon AWOI the consequences of its own deficient application form."219

In 1978, disgruntled investors in Bellmer's corporations finally did sue AWOI and twelve directors and officers. AWOI forwarded a copy of

213. Bird v. Penn Central Co., 334 F. Supp. 255 (E.D. Pa. 1971), motions denied in reh'g, 341 F. Supp. 291 (E.D. Pa. 1972).

214. Bird, 334 F. Supp. at 259.

215. 501 F. Supp. 1205 (N.D. I11. 1980).

216. Id. at 1207 .

217. Id. at 1208.

218. Although the application listed AWOI's total assets as $\$ 246,586$, the 1974 financial report indicated that when the assets of two wholly owned for-profit subsidiaries were factored in, AWOI's total assets exceeded \$3 million. AWOI's staff attorney who executed the application had listed the subsidiaries in response to a specific application question; he had answered the remainder of the questions, however, solely with respect to AWOI. Id. at 1208-09.

219. Id. at 1209. 
the complaint to National Union and requested that the insurer undertake AWOI's defense. Not surprisingly, National Union refused.

This time, in addition to its previous grounds for declaring the $\mathrm{D} \&$ $O$ void $a b$ initio, the insurer asserted a new charge, gleaned from reading the complaint filed against AWOI: Approximately three years before applyimg for D \& O coverage, AWOI allegedly had "engaged in ... investment advising and counselling activities by proinoting to its inembers investments im Bellmer's corporations."220 Not only did AWOI's staff attorney who signed the D \& $\mathrm{O}$ application allegedly know this, but boardroom minutes obtained through discovery indicated that other AWOI officials "knew of potential liability as a result of Bellmer's business dealings."221

AWOI then sued National Union for a declaratory judgment that its D \& O policy was still in effect and for recovery of its attorneys' fees on the ground of vexatious and unreasonable denial of coverage. ${ }^{222}$ AWOI denied that its officers and directors knew about and did not disclose potential claims on the application. Among other things, AWOI contended that the inherent vagueness of the preexisting knowledge clause created an unfair trap for the innocent insureds: "[N] either [the applicant] nor anyone else could have reasonably inferred fronı knowledge that AWOI loaned funds to Bellmer's conipanies that officers or directors of AWOI might be subject to hability down the proverbial road."223

Unfortunately, the important issues raised by this vagueness argument were not resolved in the district court's opinion, which was limited to granting National Union's niotion for suinniary judgment as to AWOI's deniand for attorneys' fees. ${ }^{224}$ As of April 1986, no adjudication or settlement of the underlying factual dispute had been reported.

\section{Amrep Corporation v. American Hoine Assurance Co. ${ }^{225}$}

Amrep, the first state court decision involving $\mathrm{D} \& \mathrm{O}$ application fraud, ${ }^{226}$ provides an interesting foil to Bird, Zaremba, and Automotive Wholesalers. While in those cases the insurer attempted to void the D \&

220. Id.

221. Id.

222. Id. at 1206. Insurance Code of 1937, If 155, ILL. STAT. ANN. ch. 73, If 767 (Smith-Hurd

Supp. 1986) provides for recovery of attorneys' fees on such grounds.

223. Automotive Wholesalers, 501 F. Supp. at 1209-10.

224. Id. at 1213. The court held National Union did not act unreasonably or vexatiously in denying liability, even if AWOI subsequently were to win its claim on the merits. If by its own act, innocent or otherwise, the insured contributes to a misrepresentation on the application, the insurer should not be penalized for seeking a judicial determination of the effects of that representation upon coverage. $I d$. at 1211 .

225. 81 A.D.2d 325, 440 N.Y.S.2d 244 (1981).

226. The case is only the second published state court opinion addressing D \& $O$ policy issues. The previous opinion, Flintkote Co. v. Lloyd's Underwriters, N.Y.L.J., July 27, 1976, at 6, col. 3, 
O policy almost immediately upon receiving notice of an actual or potential D \& O claim, ${ }^{227} \mathrm{im}$ Amrep the imsurer waited more than two years, until the underlymg litigation was completed, before disclaiming coverage. ${ }^{228}$ The issue addressed by the New York Appellate Division was whether, as a matter of law, the msurer had waived its right to assert application fraud by continuing to renew the policy after receiving notice that the insured's negative response to the preexisting knowledge clause was suspect.

The court held that triable issues of fact as to waiver and estoppel precluded granting Amrep's summary judgment motion. ${ }^{229}$ The court noted that since the $\mathrm{D} \& \mathrm{O}$ policy is a reimbursement policy, ${ }^{230}$ mere notification by the insured of pending litigation created neither a duty to defend nor a duty to pay expenses until an actual reimbursement claim was filed. ${ }^{231}$ Thus the relevant period of time in determining American Home's delay in disclaiming liability was reduced froin a matter of years to a inatter of months. The court held this was too short a time to constitute waiver per se. ${ }^{232}$ Second, the court questioned Amrep's assertion that because the msurer knew of lawsuits alleging acts of serious wrongdoing it was on notice to inquire into the possibility that Amrep had misrepresented its knowledge $\mathrm{m}$ response to the preexisting knowledge clause. 233 "Waiver," the court recited, "is an intentional relinquishınent

aff'd 56 A.D.2d 743, 391 N.Y.S.2d 1005 (1977), was also delivered by the New York Appellate Division.

227. See Automobile Wholesalers v. National Union Fire Co., 501 F. Supp. 1205, 1209 (N.D. III. 1980) (coverage disclaimed two months after notice of potential claim filed); Zaremba v. National Union Fire Ins. Co., 1979 Fire \& Casualty Cas. (CCH) 1302, 1303 (N.D. Ohio 1978) (coverage disclaimed shortly after D \& O claims filed); Bird v. Penn Central Co., 334 F. Supp. 255, 257 (E.D. Pa. 1971), motions denied in reh'g, 341 F. Supp. 291 (E.D. Pa. 1972) (rescission action brought before actual D \& O claims were filed).

228. American Home issued a three-year D \& O policy to Amrep Corporation in 1970 and renewed it three more times through 1978. The initial application form, which contained Amrep's negative response to the preexisting knowledge clause, was incorporated by reference into each renewal policy. Amrep, 81 A.D.2d at 326, 440 N.Y.S.2d at 246. In 1975, Amrep and several of its directors and officers were subject to civil suits and federal indictments for a variety of wrongs including criminal mail fraud. Although Amrep promptly notified American Home as to each action, American Home made no attempt to disclaim coverage during this period. Id. at 327,440 N.Y.S.2d at 246.

In late 1976, the federal charges were dismissed against three of Amrep's officials. Amrep thereafter tendered to the insurer a claim under the corporate reimbursement part of the policy for the $\$ 514,248$ it spent indemnifying the three. Following American Home's response that it needed more time to examine the trial transcripts, Amrep sued to recover on its claim. Id. In its answer, the insurer disclaimed any coverage under the policy, asserting that Amrep had committed application fraud by its negative response to the preexisting knowledge clause. Id.

229. Id. at $328-29,440$ N.Y.S.2d at $246-47$.

230. See supra note 149.

231. Amrep, 81 A.D.2d at 328,440 N.Y.S.2d at 246 . Amrep, in turn, under state law could not indemnify its officers until their lawsuits had been favorably terminated. $I d$.

232. Id. at $328-29,440$ N.Y.S.2d at 247.

233. Id. at 329,440 N.Y.S.2d at 247 . The acts of wrongdoing for which Amrep and its officials 
of a known right with full knowledge of the facts upon which the existence of the right depends." ${ }^{\text {"234 }}$ Here, "[t]he facts involved . . were complex. The possible outcome of such litigation was in doubt." ${ }^{\text {235 }}$ In such a case summary judgment would be premature. ${ }^{236}$

As of April 1986, Amrep's ultimate disposition on the merits has not been reported.

\section{Shapiro v. American Home Assurance Company ${ }^{237}$}

Three factors distinguish Shapiro from the other reported cases interpretimg the preexisting knowledge clause. First, it is the only case that acknowledges and attempts to critique the groundwork laid by the other, earher opinions. Second, because the case is the first one in which summary judgment was actually granted, it has precedential as well as expositive significance. Third, Judge Keeton went well beyond the reach of previous holdings in his legal conclusions as to the materiality of D \& $O$ application responses and the effect of misstatements upon innocent insureds.

In Shapiro, former officers of Giant Stores sought a declaration that their D \& O pohicy was in effect and covered liability incurred in five federal securities fraud cases filed against them in New York and Massachusetts. American Home, asserting application fraud, disclaimed any coverage and moved for summary judgment. The disputed policy, providing five million dollars in coverage, was first issued in 1972 and was renewable every three years. Jack Shapiro, then Giant's president, signed the application after answering "No" to the preexisting knowledge clause. ${ }^{238}$ In 1978, Shapiro was convicted, in a separate securities fraud action, for illegal acts which included filing a false corporate financial statement for 1972.239

American Home asserted that Shapiro's 1978 conviction was indisputable proof that his negative response to the preexisting knowledge clause was false. The court had no problem agreeing, reasoning that, first, filing a false financial statement as a matter of law is an "act, error

were charged and convicted began in 1964, six years prior to the company's application for D \& $O$ insurance. See United States v. Amrep Corp., 560 F.2d 539, 543 (2d Cir. 1977), cert. denied, 434 U.S. 1015 (1978).

234. Amrep, 81 A.D.2d at 329, 440 N.Y.S.2d at 247 (emphasis added) (citation omitted).

235. Id.

236. Id. Amrep also claimed that in reliance on its belief that it was covered by American Home, it did not seek alternate insurance or a less expensive defense. The court rejected the argument, noting that it "not only raises factual issues but is questionable on its face." Id. at 330 , 440 N.Y.S.2d at 247.

237. 584 F. Supp. 1245 (D. Mass. 1984).

238. Id. at 1247.

239. United States v. Lieberman, CR 77-135-S (D. Mass. Aug. 3, 1978), aff'd, 608 F.2d 889 (1st Cir. 1979), cert. denied, 444 U.S. 1019 (1980). 
or omission which might give rise to a claim" under the policy, and second, a criminal conviction for an act known but not disclosed im response to the preexisting knowledge clause is proof as a matter of law that the response was false. ${ }^{240}$

Echoing the rulings in Bird, Automotive Wholesalers, and Amrep, plaintiffs argued that summary judgment in the case nevertheless was imiproper since factual disputes existed as to the inateriality of the misstatement. The court admitted that the question whether a misrepresentation affected the insurer's underwriting decision is usually one for the jury. However, breaking new ground in the D \& O policy context, the court held that some questions on an insurance application are so central to the risk of loss that any misstatement is material as a inatter of law. The preexisting knowledge clause, the court held, fits this category. ${ }^{241}$ Under Massachusetts law, an insurance application misrepresentation which is either fraudulent or inaterial is grounds for avoiding coverage. ${ }^{242}$ Consequently, the $\mathrm{D} \& \mathrm{O}$ policy was declared void $a b$ initio, at least as to Shapiro.

The court next addressed the question whether if void for one, then void for all. The court noted that Bird had answered in the affirmative, strictly applying the doctrine of agency. The Shapiro court acknowledged, however, that in the D \& $\mathrm{O}$ insurance context, an agency relationship is often purely fictional. Outside directors and lower-level officers especially do not possess the critical element of control over acts of the higher-ranking insider completing the application. ${ }^{243}$

Rejecting the agency analysis, the court opted instead to "consider the question of . . coverage . . . as one of contract interpretation."244 Changing the name of the approach, however, did nothing to change the result. Claiming that the language of the preexisting knowledge clause

240. Shapiro, 584 F. Supp. at 1248-49. Presumably, an adverse civil judgment would have the same legal implications as a criminal conviction. What is not clear, however, is the legal effect of settlement of a suit alleging a wrongful act not disclosed on the application. Judge Keeton's ruling is especially significant to Continental Illinois Corp., which recently settled a massive shareholders' class action charging Continential Illinois Bank with misrepresenting its perilous financial condition. That misrepresentation, which also allegedly appeared in the bank's D \& O policy application, is the gravamen of its D \& O insurers' current efforts to void coverage. See supra notes $132 \& 162$. Note that Flintkote Co. v. Lloyd's Underwriters, N.Y.L.J., July 27, 1976, at 6, col. 3 (1976), aff'd, 56 A.D. $2 d 743,391$ N.Y.S.2d 1005 (1977) held that an insured's plea of nolo contendere to criminal price-fixing charges did not excuse Lloyd's from coverage under the criminal act exclusion of its D \& $O$ policy. Although a criminal-act exclusion is distinguishable from the preexisting knowledge clause, an insured may have similar, innocent reasons to settle to plead nolo contendere.

241. Shapiro, 584 F. Supp. at 1249-50.

242. MASS. Gen. LAwS ANN. ch. $175, \S 186$ (West 1972). Factoring Judge Keeton's per se materiality rule into the existing statute effectively elevates the response to the preexisting knowledge clause to the status of a warranty: mere falsity is grounds for voidance.

243. Shapiro, 584 F. Supp. at 1251-52.

244. Id. at 1252. 
was "straightforward," the court concluded that the intent of the parties appeared to be against severability of coverage: ${ }^{245}$

Because of the likelihood of joint and several liability being imposed on all directors for the wrongdoing of one, the facts known by Shapiro were highly material not only to his potential liability, but to that of all other directors. Since Shapiro's answer misrepresented the risk incurred in insuring all those covered by the policy, it follows that American Home can avoid responsibility to all the insureds on the basis of misrepresentation. ${ }^{246}$

In addition to misrepresentation, the court held that the exclusion clause provided a second absolute defense to coverage. Unlike the preexisting knowledge clause, it noted, the exclusion clause is not tied to a misrepresentation standard, but operates objectively as a condition precedent to coverage. Liability does not arise from any claim stemining from facts which are known by any director or officer at the time of the application. Since the claims against Shapiro were based on occurrences he knew about in 1972, those claims were excluded. ${ }^{247}$ Although the plaintiffs vigorously objected to it as harsh and unfair, the court concluded that such an interpretation of the exclusion clause was neither unconscionable nor against public policy. ${ }^{248}$

\section{III}

\section{Analysis of the Preexisting Knowledge Clause}

Until courts focus inore attention on the function and language of the preexisting knowledge clause, it is unlikely that future disputes involving the interpretation of the clause will be resolved with any inore precision or consistency than the cases to date. Although the cases reviewed in Part II presented an array of factual and legal issues, the core of each dispute seemed to stem from deficiencies in the preexisting knowledge clause as drafted. This Part will reorganize and catalogue those deficiencies for purposes of analysis. Broadly speaking, the deficiencies can be grouped into three categories: vagueness, anniguity, ${ }^{249}$ and unconscionability. After analyzing each deficiency, this Part will suggest a framework for adjudicating disputes. Part IV will propose suggestions for restructuring the preexisting knowledge clause to elininate these deficiencies altogether.

\footnotetext{
245. Id.

246. Id.

247. Id.

248. Id. at 1253.

249. Whereas "vagueness" refers to an aspect of the clause which is so indefinite as to elude any precise understanding as to scope or intent, "ambiguity" refers to an aspect which is susceptible to either of two commonly understood meanings. See WEBSTER's THIRD NEW INT'L DICTIONARY 66, 2528 (P. Gove ed. 1971).
} 


\section{A. Vagueness}

\section{Breadth of Disclosure}

As the insured in Automotive Wholesalers ${ }^{250}$ argued, the primary problem with the preexisting knowledge clause is its exceptional vagueness as to the scope and nature of the information it requests. The crux of this vagueness lies in the unpredictability of the source of liability today. As discussed previously, there has been an explosion in the nuinber and variety of causes of action instituted against corporate executives, spurred by the advent of shareliolder derivative suits and fanned by the increased volume of mergers and acquisitions. ${ }^{251}$ The variety of $D$ \& O claims reported to the Wyatt Company im its 1984 survey is especially telling, prompting the company to acknowledge the extreme "difficulty in predicting the bringing of a claim against the directors or officers of any given company."252

In today's hostile-takeover environment, iromically, not even the most capable directors and officers can feel assured that their actions will be litigation-proof. "As many msurers point out, corporations with stable earnings, excellent management and modest debts-tlie ideal risks of old-now rank as prime takeover candidates. In short, it lias become all but impossible to predict this potentially linge risk."253 Moreover, because the courts in recent years liave greatly mcreased emphasis on the fiduciary role of corporate directors and officers, ${ }^{254}$ these directors and officers increasingly are subject to liability for acts of minor and passive negligence. As a result, it is exceptionally difficult for the typical corporate officer or director, who often possesses little or no legal training, to even comprehend, let alone catalogue, the broad range of "acts, errors or omissions that miglit give rise to" professional liability.

Recoguizmg the inherent uncertainty surrounding the potential sources of lawsuits agamst corporate directors and officers, $\mathrm{D} \& \mathrm{O}$ insurers could have attempted to ameliorate the problem by drafting a reasonably concrete, specific inquiry. Life and health insurance policy applications, for example, routmely provide the applicant with a cliecklist covering the gamut of individual diseases, illnesses, injuries, and conditions potentially giving rise to a coverage claim. ${ }^{255}$ The checklist

250. 501 F. Supp. at 1209-10.

251. See supra notes 13-73 and accompanying text.

252. 1984 WYATT SURVEY, supra note 1 , at 10 . Out of 540 separate allegations contained in D \& O claims filed in 1984, 340 could be categorized into seven broad groups; the remaining 200 were identified as "Other" types. This latter segment included 131 allegations falling into nine subcategories, plus 69 allegations which did not fit into any category. Id.

253. Ipsen, supra note 25, at 233.

254. See, Albert v. 28 Williams St. Corp., 63 N.Y.2d 557, 568-69, 473 N.E.2d 19, 25-26, 483 N.Y.S.2d 667, 673-74 (1984) (providing citations).

255. See infra note 376 . 
enables the insured to provide simple responses to concrete requests for factual information. ${ }^{256} \mathrm{~A}$ catchall type question at the end serves to plug loopholes and to elicit information missed by the preceding list. However, to the extent that this catchall question is itself vague, modern courts often have been reluctant to enforce it. ${ }^{257}$

The majority of D \& O liability insurers, however, has chosen not to incorporate a checklist or other form of directed inquiry and instead rehes upon a single catchall-type question. Underwriters might argue with some justification that it would be extremely difficult to draft a valid, knowledgeable hist of lawsuit-inducing acts by a corporate director or officer and virtually impossible to make such a list complete. Lest the underwriter be held to the axiom expressum facit cessare tacitum, ${ }^{258}$ it must instead rely on a broad query. An obvious reply is that if an insurance underwriter, who specializes in assessing risk, cannot draft a reasonably comprehensive, rehable question, then the corporate official completing the application should not be expected to provide a comprehensive, rehable response. ${ }^{259}$

Connecticut Mutual Life Insurance Co. v. McWhirter, ${ }^{260}$ decided by the Nimth Circuit Court of Appeals in 1896, remains aptly representative of the courts' disdain for vaguely worded provisions in an insurance pol-

256. In many jurisdictions, responses to these fact-oriented application questions are interpreted as warranties. See infra notes 291-97 and accompanying text.

257. See, e.g., Jefferson Standard Life Ins. Co. v. Anderson, 236 Cal. App. 2d 905, 46 Cal. Rptr. 480 (1965), in which the court refused to give effect to a catchall-type question on a life insurance application which it deemed overly simplistic and vague. Following a detailed questionnaire about specific ailments and injuries, the application asked "Have you ever been a patient in a hospital?" The applicant answered, "No." In reality, he had entered a hospital three years earlier for a fourday checkup, which disclosed no ailments. Id. at 907-08, $46 \mathrm{Cal}$. Rptr. at 482 . When the insured died of artery disease two years later, the insurer sued the beneficiary to void the policy on grounds of applieation misrepresentation. The court nevertheless euforced the policy. Id. at $913,46 \mathrm{Cal}$. Rptr. at 486. Citing the question's lack of specificity, the court stated:

In Cohen v. Penn Mut. Life Ins. Co, supra, 48 Cal.2d 720, 723, the court considered a form of application which specifically inquired of the proposed insured whether he "ever had a health or physical examination," or had "ever been in a clinic, hospital, sanitarium, or asylum for observation, treatment or diagnosis," and asked for "dates, reasons, names and addresses of persons who made examinations." (Italics added.) The specificity of the questionnaire under consideration in the cited case points up the generality with attendant ambiguity of that in the instant case.

Id. at 913, 46 Cal. Rptr. at 485-86.

In addition, because of the checklist of serious ailments and injuries immediately preceding "Have you ever been a patient in a hospital?" the applicant "was entitled to conclude that the inquiry was directed to his being in the hospital on account of a [serious] ailment or injury from which he was suffering." Id. at 913, 46 Cal. Rptr. at 485 . See infra notes 355-63 and accompanying text.

258. "The express mention of certain things excludes those not mentioned." LATIN WORDS \& Phrases For LAWyers 85 (R. Vasan ed. 1980).

259. See, e.g., National Old Line Ins. Co. v. People, 256 Ark. 137, 143-44, 506 S.W.2d 128, 132 (1974) (Harris, C.J., concurring).

260. 73 F. 444 (9th Cir. 1896). 
icy. McWhirter's insurer attempted to void his life insurance policy by claiming breach of warranty. It asserted that McWhirter incorrectly responded to a question on the policy application, although he had warranted its correctness. ${ }^{261}$ The question, presented at the end of a long series of interrogatories, asked: "Is there any fact relating to your physical condition, personal or family history, or habits, which has not been stated in the answer to the foregoing question, and with which the company ought to be made acquainted?"262 McWhirter answered, "No," and the insurer thereupon issued the policy.

Not long thereafter, McWhirter was found lying in his back yard, shot through the heart. Upon an investigation by the insurance coinpany, friends of McWhirter revealed that at times he had acknowledged that he had political enemies and that his life had been threatened. On this ground the insurance company sued to void the contract. ${ }^{263}$ The court was not persuaded to void the policy on the strength of the disputed application question. It held that due to its inherent vagueness, the question could only be classified as calling for an opinion on the part of McWhirter:

Certainly, in considering whether there was any matter connected with his personal history which the company ought to know, he must determine that it would not be required of him to state that he had played marbles when a boy, had been whipped at school, or had loved his wife when he married her. When an opinion is asked, all that could be required would be an honest answer. ... [1]t would hardly be thought that [McWhirter] would consider it an important matter to state that he had enemies, political enemies, and his life had been threatened by them. ... [B]ut would an insurance company consider such matters important, when taking the application of a person seeking life insurance? I cannot think it would. If so, then such companies had better enlarge their long list of exhausting questions, and not leave it to the judgment of applicants for insurance policies to make known such matters. ${ }^{264}$

Although drafted more than fifty years after the question rejected by the court in McWhirter, the preexisting knowledge clause does little to inprove upon the vagueness of that earlier provision.

\section{Scope of Inquiry}

A second aspect of the preexisting knowledge clause's vagueness involves the lack of direction provided to the applicant regarding the duty, if any, to ascertain the knowledge of the other directors and officers

261. Id. at 445 .

262. Id.

263. Id.

264. Id. at 450-51. 
before responding. On the one hand, most $D \& O$ insurers require that a single officer execute the policy. The application informs the signator that his statements must be true "to the best of his knowledge."265 On the other hand, the clause as worded requests a response as to the knowledge of all the directors and officers. Yet no guidance is given as to what due diligence, if any, is required of the applicant before signing. Should the siguator informally interview or poll each prospective insured; ${ }^{266}$ distribute copies of the entire application for individual review so that the preexisting knowledge clause is seen in context; request a signed response from eacli director and officer? The application is silent as to any of these options. ${ }^{267}$ Yet, depending on whether the applicant engages in a narrow or broad inquiry, the information provided in response to the preexisting knowledge clause might vary siguificantly. This vagueness in the clause renders it unreliable as a vehicle with which to elicit compreliensive, accurate information.

\section{Relationship Among the Insureds}

Finally, the application is vague as to the nature of the relationship between the applicant and the other officers and directors, and between each nonsigning insured and the others. It is an open question whether or not agency or some other contractual or imphed relationship exists. If, as the insurers have generally asserted, ${ }^{268}$ the applicant acts as the legal agent for the corporation and the other directors and officers, then some of the guidelines which the insurers left out of the application would be implied by law. First, the scope of the applicant's inquiry witl each insured would be clarified since an agent, as a fiduciary, ${ }^{269}$ would be compelled to consult with each principal before purporting to speak for them. Second, and more important, the effects of the applicant's dishonesty upon coverage of "innocent" officers and directors would be clarified since, under strict rules of agency, the knowledge of the agent is imputed to the primcipal. ${ }^{270}$

265. M. SCHAEFTLER, supra note 30 , at 276 (emphasis added).

266. In 1969 the opinion of the underwriting industry was that an individual poll was unnecessary and probably "a futile exercise," given the perceived disinclination of the one polled to admit to negligence. Instead, the insurers depended on receiving accurate information by requiring that only a high-ranking officer-one presumed to be fully familiar with both the inner workings of the corporation and the activities of the other insureds-execute the application. See PRACTISING LAW INST., supra note 157, at 212 (V. Stahl, a respresentative of Marsh \& McLennan insurance brokers, speaking).

267. As Judge Thomas noted in Zaremba v. National Union Fire Ins. Co., 1979 Fire \& Casualty Cas. (CCH) 1302, 1305 (N.D. Ohio 1978), "if [the insurer] desired to have each director and officer personally give the best of his knowledge . . . the application could have required each officer and director to answer ... . [The insurer] is entitled to only that information it requested."

268. See supra notes 175-248 and accompanying text.

269. See RESTATEMENT (SECOND) OF AGENCY $\S 13$ (1958) (Agent as Fiduciary).

270. See, e.g., 7 G. COUCH, Couch ON INSURANCE $\S 35: 158$ (2d ed. 1985) ("Representations 
Yet, as the opinions in both Zaremba and Shapiro pointed out, an agency relationship between applicant and potential insureds is not a foregone conclusion, especially in the $\mathrm{D} \& \mathrm{O}$ context. ${ }^{271}$ The language in the application generally is silent, or worse, misleading, as to the representative capacity of the signator. ${ }^{272}$ Moreover, notwithstanding the insertion of contractual labels, an agency relationship requires that the principal be in a position of control over the agent and inaunfest her consent that the agent act in her behalf. ${ }^{273}$ In the D \& O context, arguably neither of these conditions is met. First, because a high-ranking officer or inside director generally is required to execute the application, ${ }^{274}$ she is unlikely to be subject to the actual control of the others. ${ }^{275}$ The "intimidation factor" inay work against any attempt to exercise control as lower-level officers, "justifiably fearing for their career, are hikely to overlook suspicious behavior on the part of a superior." 276 Second, as to the requirement that each principal manifest consent, nothing in the $\mathrm{D} \& \mathrm{O}$ policy or application requires that the application be shown to prospective insureds other than the applicant. ${ }^{277}$ Two defendant directors in Bird, for example, went so far as to assert that they had no prior knowledge that their coinpany had even applied for a D \& O policy. ${ }^{278}$

The argument for an agency relationship becomes even more attenuated in situations where the one failing to disclose preexisting knowledge is soineone other than the policy applicant. ${ }^{279}$ Indeed, as the sheer

... made ... on the basis of the opinion or information of the insured's agent ... [are] the same as though . . . made by the insured, and the actual mnocence or good faith of the insured is immaterial.") (footnote omitted).

271. Zaremba v. National Union Fire Ins. Co., 1979 Fire \& Casualty Cas. (CCH) 1302, 1304-05 (N.D. Ohio 1978); Shapiro v. American Home Assurance Co., 584 F. Supp. 1245, 1251-52 (D. Mass. 1984); see supra notes 199-206, 243 and accompanying text.

As the Restatement of Agency points out, neither the board of directors nor an individual director is, as such, an agent of the corporation or of its directors and officers. Limitations on control stand in the way. RESTATEMENT (SECOND) of AGENCY $§ 14 C$ (1958). An officer, on the other hand, is necessarily an agent of the corporation, but not of the board of directors or her fellow officers. Id. Any agency relationship, therefore, would have to be a specially created for a particular transaction.

272. See Zaremba, 1979 Fire \& Casualty Cas. (CCH) at 1306 (holding that application's reference to signator as officer of corporation precludes signator's role as agent of individual insureds).

273. REstatement (SECOND) OF AGENCY § 1(1) (1958).

274. See supra note 266.

275. See Shapiro, 584 F. Supp. at 1251.

276. See Heaney, So Your Insurance Is Up For Renewal, ABA BANKing J., Jan. 1986, at 79, 8081.

277. See M. SchaEFTLER, supra note 30 , at $275-76$.

278. See Bird v. Penn Central Co., 334 F. Supp. 255, 261 (E.D. Pa. 1972).

279. Unless each insured is held the agent of every other insured, the court will have to resort to a process of "double-imputation" to charge an innocent policy applicant with the knowledge of the nondisclosing director or officer. See Zaremba v. National Union Fire Ins. Co., 1979 Fire \& Casualty Cas. (CCH) 1302, 1305-06 (N.D. Ohio 1978) (court rejected double-imputation, citing 
number of directors and officers seeking coverage under a single $\mathrm{D} \& \mathrm{O}$ policy grows, the control and assent necessary for an agency relationship will be more and more fictional. Consequently, it is unfair first to impute agency without the traditional prerequisites of consent or control and then enforce the harsh consequences that traditional agency theory entails.

If, on the other liand, the court liolds that there is no agency relationship, it is left with even less guidance for adjudicating coverage disputes. The current vagueness of the preexisting knowledge clause keeps the court fettered to case-by-case factual inquiries inimical to the development of consistent rules in this area.

\section{B. Ambiguity}

\section{Warranty or Representation?}

The majority of $\mathrm{D} \& \mathrm{O}$ policy applications do not specify whether the response to the preexisting knowledge clause inust be a warranty of fact or a representation of good faith belief. Depending on how the clause is interpreted, the corporate applicant is held either to an objective or subjective standard of accountability.

[R]epresentations ... do not void the contract, even though untrue in fact, provided they were honestly made in the belief by insured that they were true. That is, they must be both untrue and knowingly falsely made by insured. ...

[Where a warranty is involved,] a state of forgetfulness, or a mistake, on the part of the applicant will not excuse the omission to furnish the information required; and this regardless of whether the withheld facts may appear to have affected the risk assumed. ${ }^{280}$

Most state insurance codes establish rigorous standards of honesty for dealings between parties to the insurance contract. ${ }^{281}$ Notwithstanding the harsh tone of inany of the provisions, which, to the extent they allow rescission for any material false statement, tend to collapse the distinction between warranty and representation, ${ }^{282}$ courts generally have

exception to imputation doctrine when agent acts adverse to the interests of principal); see supra text accompanying notes 205-07.

280. Northern Life Ins. Co. v. King, 53 F.2d 613, 616-17 (9th Cir. 1931); see also Zaremba, 1979 Fire \& Casualty Cas. (CCH) at 1306-07.

281. The California Insurance Code is representative. By its terms, virtually any communciation can be characterized as a warranty. See, e.g., CAL. INS. CodE $\S 330$ (West 1982) (defining concealment as "Neglect to communicate that which a party knows, and ought to communicate, is concealment."); id. $\S 331$ ("Concealment, whether intentional or unintentional, entitles the injured party to rescind insurance."); id. $\S 441$ ("A statement in a policy of a matter relating to the person or thing insured, or to the risk, as a fact, is an express warranty thercof."); id. $\S 442$ ("A particular form of words is not necessary to create a warranty.").

282. Compare, e.g., id. $\S 359$ ("If a representation is false in a material point, whether 
taken great pains to maintain the distinction between the two. While allowing the code to impose an objective truth standard on bona fide warranties, the courts have persistently sought ways of preventing inere falsity of representations froin constituting breach. ${ }^{283}$

As to the threshold question of whether the preexisting knowledge clause in a D \& O policy should be construed as a warranty or representation, most state insurance statutes are not dispositive. Indeed, the statutes generally provide fertile ground for extracting arguments in support of either interpretation. The California Insurance Code is illustrative. On the one hand, since the knowledge or information of the directors and officers relates "to the person or thing insured, or to the risk, as a fact," ${ }^{284}$ the clause appears clearly to fit the statutory definition of "express warranty."285 Furthermore, while the application does not stipulate that the clause is a warranty, the Code acknowledges that "a particular form of words is not necessary to create a warranty;"286 thus, such an interpretation is permissible. Finally, the Code, which requires that particular types of insurance policies stipulate in writing that all statements contained therein are representations and not warranties, ${ }^{287}$ requires no sucl stipulation in liability policies. Because not prolibited, warranties presumably are permitted in these latter policies, and a D \& O insurer might argue, in reliance on this statutory presumption, that it

affirmative or promissory, the injured party is entitled to rescind the contract from the time the representation becomes false.") with id. $\S 447$ ("The violation of a material warranty or other material provision of a policy, on the part of either party thereto, entitles the other to rescind.").

For a critique of these and other California Insurance Code sections, see Patterson, Some Contract Provisions of the California Insurance Code, 32 S. CAL. L. REV. 227 (1959).

283. First, the courts have made an effort to restrict the definition of "materiality" and thereby save an applicant's misrepresentation from constituting breach by labeling it "nonmaterial." For example, even when the application asks a specific factual question, which traditionally rendered the answer material as a matter of law, an applicant in certain cases is no longer held in breach for providing a false answer. See, e.g., Jefferson Standard Life Ins. Co. v. Anderson, 236 Cal. App. 2d 905, 910, 46 Cal. Rptr. 480, 484 (1965).

Second, some courts have placed such a heavy burden of proving misrepresentation upon the insurer that they arguably establish a conclusive presumption against material misrepresentation by the insured. See, e.g., Thompson v. Occidental Life Ins. Co., 9 Cal. 3d 904, 916, 513 P.2d 353, 360, 109 Cal. Rptr. 473, 480 (1973).

Finally, the courts have interpreted the statutes to require that an applicant guilty of misrepresentation or concealment as to certain life and health insurance policy responses possess both present knowledge of the true facts sought and an appreciation of the significance of those facts. See, e.g., Traveler's Ins. Co. v. Byers, 123 Cal. App. 473, 478, 11 P.2d 444, 446 (1932); infra notes 357-63 and accompanying text.

284. CaL. INS. CodE $\S 441$ (West 1972).

285. Id.

286. Id. $\S 442$.

287. These stipulated-language policies include life and disability insurance policies, $i d . \S 10113$, funeral insurance policies, id. $\S 10244(4)$, group life insurance policies, id. $\S 10207$, and group disability insurance policies, id. $\S 10270.6$. 
intended all application statements to be warranted..$^{288}$

On the other hand, the Code also allows an interpretation of the preexisting knowledge clause as a representation. First, to counter the argument made $\mathrm{m}$ the preceding paragraph, the fact that the Insurance Code requires a variety of types of insurance policies to stipulate in writing that the statements contained therein are representations and not warranties suggests that warranties in general are statutorily disfavored in msurance policies. Therefore, when it is not clear whether a statement slould be construed as a warranty or representation, the courts should presume it to be a representation. ${ }^{289}$ Moreover, the Code stipulates that an insured is not "bound to communicate, even upon inquiry, information of his own judgment upon the matters in question."290 Responses to the preexisting knowledge clause are necessarily based on the judgment of the respondent. Thus, if enforceable at all, ${ }^{291}$ the clause should be lield, at most, to a representation standard.

Considering the lack of guidance provided by state insurance codes, $\mathrm{D} \& \mathrm{O}$ underwriters would have done well to stipulate in the policy the imtended status of application responses. Instead the application is silent both as to whetler answers to the preexisting knowledge clause are warranties or representations and as to the effect upon coverage of a deficient response. As a result, when disputes arise, the parties have had to stretch the policy and application language to craft arguments in favor of one interpretation or the other. Unfortunately for the courts, the preexisting knowledge clause is susceptible to eitlier characterization.

On the one hand, the operation of the exclusion clause, which automatically rescinds the coverage of any claim steinming from knowledge or information not disclosed in the preexisting knowledge clause, gives the latter the practical effect of a warranty. The very existence of the exclusion clause in the apphication arguably evidences the parties' intent

288. Note, however, Judge Lord's exhortation in Bird that the mere absence of a policy provision which appears in other types of policies is not valid grounds to assume the absence was intended. Bird v. Penn Central Co., 334 F. Supp. 255, 258 (E.D. Pa. 1972); see supra note 181.

289. The fact that two of these policies statutorily bound to a representation standard are group life and group disability, see supra note 287 , is especially noteworthy since a $D$ \& $O$ policy also covers a group situation. The inference is that where numerous insureds are involved it is more difficult for a single applicant to warrant as fact information concerning all the insureds.

290. CAL. INS. CODE $\S 339$ (West 1982).

291. Although CAL. INS. CODE $\S 339$ does not expressly prohibit an insurer from asking the applicant a question calling for his own judgment, it prohibits the insurer from requiring an ansiver. Nevertheless, the nature of the preexisting knowledge clause is such that, unless it is completely answered, the application most likely will not be processed or approved. To this extent, the contract resembles a contract of adhesion. See infra note 305 and accompanying text.

Moreover, to the extent the clause requires information that the applicant by statute need not communicate, it overreaches. Adhesion and overreaching are two traditional indicia of unconscionability, upon a finding of which courts may refuse to enforce a contract provision. See infra notes $300-40$ and accompanying text. 
that responses to the preexisting knowledge clause be warranties. ${ }^{292}$ Moreover, the insurer's act of incorporating the application into the policy and attaching it with the words "in consideration of . . . statements made to the Insurer by apphication, [insurer] agrees . . ." indicates the inportance that the insurer places on the application responses in reacl1ing its decision to insure. ${ }^{293}$ The law generally presumes that application responses are warranties when they are incorporated into the policy. ${ }^{294}$

On the other liand, the $D$ \& $O$ application also supports interpreting the clause as a representation. As the court ruled in Zaremba, the inere fact that the application is incorporated into the policy does not necessarily inake all such statements therein warranties. ${ }^{295}$ Moreover, the stateinent at the bottoin of the application-"The undersigned autliorized officer of the organization declares that to the best of his knowledge the statements set forth herein are true"296-implies that the information supplied will be tested as a matter of good faith belief ratlier than as a inatter of fact. Finally, the preexisting knowledge clause closely reseinbles a preexisting illness clause found in inost hife and liealth/hospitalization insurance pohcies, which are construed by the majority of courts to be representations. ${ }^{297}$

Thus, the policy language also offers no clear-cut basis for assuming warranty or representation. The distinction between warranty and representation, however, dramatically affects not only the court's approach in determiming whether there was a breach, but also the approach taken by the applicant in answering the provision. Whereas an applicant iniglit respond to a representation clause after a few moinents of good faitl reflection, the same applicant, when faced with what he identifies as a warranty, might opt to reserve his answer until such time as he could complete a inuch inore thorough inquiry, one involving the other named insureds. The resulting response to the preexisting knowledge clause following such an inquiry might differ significantly from the applicant's earlier, perhaps less diligently investigated response.

292. This was the conclusion of Judge Keeton in Shapiro v. American Home Assurance Co., 584 F. Supp. 1245, 1252 (D. Mass. 1984).

293. M. SCHAEFTLER, supra note 30 , at 277 . The application itself states: "[I]t is agreed that this form shall be the basis of the contract should a policy be issued, and it will be attached to the policy." It further state that "the application is attached to the policy, so it is necessary that all questions be answered in detail." Id. at 276.

294. G. Couch, supra note 270, at § 35:128; see Zaremba v. National Union Fire Ins. Co., 1979 Fire \& Casualty Cas. (CCH) 1302, 1307 (N.D. Ohio 1978). The court in Zaremba, however, emphasized the exception to this rule. Id; see supra note 210 and accompanying text.

295. Zaremba, 1979 Fire \& Casualty Cas. (CCH) at 1306-07.

296. M. SCHAEFTLER, supra note 30 , at 276 (emphasis added).

297. See infra notes 351-71 and accompanying text. 


\section{Ambiguous Terminology}

The imprecise language employed in the preexisting knowledge clause creates ambiguities that materially affect the clause's interpretation. The clause asks, "Does any Director or Officer have knowledge or information of any act, error or omission which might give rise to a claim under the proposed policy?"'298 According to Webster's Dictionary, "might" can be used to express degrees of likelihood ranging from "probability" to "less probability or possibility than may (e.g., "lie miglit get there before it rams')."299 As a result, the meaning of the preexisting knowledge clause can vary dramatically, ranging from a request for knowledge of an act, error, or omission that probably will give rise to a claim, to one which possibly could give rise to a claim. Depending upon how the policy applicant imterprets "miglit," the breadth and scope of her imquiry and resulting response could vary immensely.

The multiple meanings of the term "might" also makes the scope of the exclusion clause uncertain. It is understood that "such knowledge and information" denied coverage under the exclusion clause refers to that knowledge and information cited in the preexisting knowledge clause, that is, knowledge or information of facts that might give rise to a claim. Since virtually any act, error or omission could possibly give rise to a claim, the interpretation of "miglit" as "possibly could" would subject a vastly wider range of actions to exclusion from coverage than would the stricter interpretation.

It is also unclear whether a subjective or objective standard ought to apply in determining if a particular act, error, or omission "might give rise to a claim." On the one hand, the test could require that the insured both knew of the act and personally believed it capable of producing a lawsuit. Alternatively, the test could be whether the insured knew about the act, which a reasonably prudent director or officer (or perliaps a reasonably prudent insurer) would believe capable of producing a lawsuit. Adoption of the former, subjective standard, of course, would render more difficult the insurer's effort to prove breacli based on nondisclosure.

A third ambiguity, evident from evaluating the exclusion clause in tandem with the preexisting knowledge clause, is that there are two distinct possible temporal referents of the term "sucl knowledge or information." As noted above, it is clear that the adjective "sucli" in the exclusion clause modifies "knowledge and information" contained in the preexisting knowledge clause. However, it is not at all clear whether "sucl knowledge" refers to (1) knowledge or information of facts believed (wliether subjectively or objectively) at the time of the applica-

298. M. SCHAEFTLER, supra note 30 , at 275 (emphasis added).

299. Webster's THIRD NeW WORLd INT'L Dictjonary 1432 (P. Gove ed. 1971). 
tion to be capable of giving rise to a claim (whether possibly or probably) or (2) knowledge or information of those facts that ultimately did give rise to a claim.

The exclusion clause operates prospectively froin the time of the application to exclude froin coverage all potential claims arising from facts listed by the applicant in response to the preexisting knowledge clause. However, the exclusion clause also operates at the time a claim actually is filed to invalidate that claim if it is determined that "sucli knowledge" existed at the time of the application. Under this interpretation the clause acts as a condition precedent to coverage. If "such knowledge" refers to any knowledge of facts that actually gave rise to a lawsuit, then virtually all claims arising from events that occur before the policy application could be disallowed.

\section{Unconscionability}

\section{The Unconscionability Doctrine and $D \& O$ Insurance}

An unconscionable contract transaction generally is cliaracterized by a disparity of bargaining power between the parties, emanating from a larsli coininerical setting in which one party lacks a meaningful clroice. ${ }^{300}$ The potential unconscionability of the preexisting knowledge clause lies not only in elements of substantive unfairness, but also in the unconscionable effects, sucli as unfair surprise, produced by the clause in operation with the exclusion clause.

To date, a limited number of reported cases liave cited "unconscionability" as the ground for disallowing an insurance contract provision. $^{301}$ One explanation for the paucity of cases in the insurance context

300. See C \& J Fertilizer, Inc. v. Allied Mutual Ins. Co., 227 N.W.2d 169, 181 (Iowa 1975) (facts discussed infra note 312); Annotation, Doctrine of Unconscionability as Applied to Insurance Contracts, 86 A.L.R.3d 862, 866 (1978).

301. See, e.g., Steven v. Fidelity \& Casualty Co., 58 Cal. 2d 862, 377 P.2d 284, 27 Cal. Rptr. 172 (1962) (literal application of substituted transportation provision in travel insurance policy held unconscionable); Western \& Southern Life Ins. Co. v. Vale, 213 Ind. 601, 12 N.E.2d 350 (1938); C \& J Fertilizer, Inc. v. Allied Mut. Ins. Co., 227 N.W.2d 169 (Iowa 1975) (en banc); Breland v. Louisiana Hosp. Services, Inc., 468 So. 2d 1215 (La. Ct. App. 1984); Roach v. Central Nat. Ins. Co., 60 Mich. App. 40, 230 N.W.2d 297 (1975); Gulf Guaranty Life Ins. Co. v. Kelly, 389 So. 2d 920 (Miss. 1980) (invocation of clause allowing policy cancellation within 90 days of issuance held unconscionable where insured, having suffered heart attack one week after issuance, was rendered virtually uninsurable); Yankelevitz v. Royal Globe Ins. Co, 107 Misc. 2d 636, 435 N.Y.S.2d 900 (1980), rev'd on other grounds 88 A.D.2d 934, 934, 451 N.Y.S.2d 166, 167 (1982); Carr v. Maryland Casualty Co., 88 Misc. 2d 424, 388 N.Y.S.2d 196 (1976);

Cases in which courts have endorsed the doctrine of unconscionability as applicable to insurance contracts, but ultimately decided the contract at hand was not unconscionable include: Willden v. Washington Nat. Ins. Co., 18 Cal. 3d 631, 557 P.2d 501, 135 Cal. Rptr. 69 (1976); Home Federal Sav. \& Loan Ass'n v. Campney, 357 N.W.2d 613, 618-20 (Iowa 1984); Auto-Owners Ins. Co. v. Traviss, 72 Mich. App. 66, 248 N.W.2d 673 (1976); Hospital Service Plan v. Phillips, 126 N.J. Super. 246, 313 A.2d 811 (1973); Standard Venetian Blind Co. v. American Empire Ins. Co., 503 Pa. 
is the ready availability of other theories and remedial procedures. ${ }^{302}$ Yet at least two commentators feel that, in many cases where courts obviously have stramed to apply theories of waiver or estoppel to enforce insurance coverage or have artificially read ambiguity into a policy provision $\mathrm{i}$ order to reconstruct it, unconscionability is the more accurate and defensible theory. ${ }^{303}$

The courts, in fact, have long recoguized the superior bargaining power of an insurance company over its insured-a factor present in most unconscionable transactions. ${ }^{304}$ Insurance policies generally are considered contracts of adhesion, "under which the insured is left little choice beyond electing among standardized provisions offered to him. ....305

In the $\mathrm{D} \& \mathrm{O}$ insurance arena, however, it might be expected that theories of unconscionability would fare rather unsuccessfully, considermg that a D \& O pohicy is essentially a contract between two corpora-

300, 469 A.2d 563 (Pa. 1983); Bishop v. Washington, 331 Pa. Super. 387, 397-404, 480 A.2d 1088, 1093-96 (Pa. 1984); Cline v. Safeco Ins. Cos., 614 P.2d 1335 (Wyo. 1980) (plumbers' liability policy).

302. These theories and doctrines include the following: contra proferentem (see infra notc 342 and accompanying text; see e.g., Gaunt v. John Hancock Mut. Life Ins. Co., 160 F.2d 599 (2d Cir. 1947), cert. denied, 331 U.S. 849 (1947)); waiver and estoppel (see, e.g., Miller v. Elite Ins. Co., 100 Cal. App. 3d 739, 753-56, 161 Cal. Rptr. 322, 330-31 (1980)); reasonable expectations (see, e.g., Carper v. State Farm Mut. Ins. Co., 758 F.2d 337 (8th Cir. 1985)); abuse of rights (see, e.g., Breland v. Louisiana Hosp. Serv., Inc., 468 So.2d 1215 (La. 1984); Cueto-Rua, Abuse of Rights, 35 LA. L. REv. 965 (1975)); continuing loss (see, eg., Home Insurance Co. v. Heck, 65 Ill. 111 (1872) (insurer prohibited from cancelling fire insurance policy in the face of an advancing fire)); bad faith (see, e.g., Egan v. Mutual of Omaha Ins. Co., 24 Cal. 3d 809, 620 P.2d 141, 169 Cal. Rptr. 691 (1979)); failure or lack of consideration (see, e.g., Laitner Plumbing and Heating Co. v. McThomas, 61 S.W.2d 270, 272 (Mo. App. 1933)); and the ubiquitous public policy concerns (see, eg., Brown v. Blue Cross \& Blue Shield., 427 So.2d 139 (Miss. 1983)). See generally C \& J Fertilizer, Inc. v. Allied Mut. Ins. Co., 227 N.W.2d 169, 175 (lowa 1975) ("Nor can a lawyer in the ordinary sense be faulted for not risking a client's cause on an uncharted course when there is a reasonable prospect of reaching a fair result through familiar channels of long-accepted legal principles . . . .").

303. Keeton, Insurance Law Rights at Variance with Policy Provisions, 83 HARv. L. REv. 961, 964-65 (1970); Llewellyn, Book Review, 52 HARv. L. Rev. 700, 702-03 (1939) (explaining why "[c]overt tools are never reliable tools" in contract construction); see also J. Calamari \& J. Perillo, Contracts 320-21 (2d ed. 1977).

304. Bishop v. Washington, 331 Pa. Super. 387, 397-98, 480 A.2d 1088, 1093 (1984); see also Yankelevitz v. Royal Globe Ins. Co., 107 Misc. 2d 636, 435 N.Y.S.2d 900 (1981), rev'd on other grounds 88 A.D.2d 934, 934, 451 N.Y.S.2d 166, 167 (1982); G. CORBIN, CORBIN ON CONTRACTS $\S 1376$ at 21 (1962) ("Standardized contracts such as insurance policies ... are carefully scrutinized by the courts for the purpose of avoiding enforcement of 'unconscionable' clauses."); R. KEETON, BASIC TEXT ON INSURANCE LAW 348-49 (1971).

305. C \& J Fertilizer, Inc. v. Allied Mut. Ins. Co., 227 N.W.2d 169, 175 (Iowa 1975) (en banc) (quoting Keeton, supra note 303, at 966; see also Rodgers v. Pennylvania Life Ins. Co., 539 F. Supp. 879, 883 (S.D. Iowa 1982); Beynon v. Garden Grove Medical Group, 100 Cal. App. 3d 698, 705, 161 Cal. Rptr. 146, 150 (1980) (group health care plan); W. VANCE, HaNDBooR on thl LAW of INsurance 243 (3d ed. 1951). But cf. Robin v. Blue Cross Hosp. Service, Inc., 637 S.W.2d 695, 697 (Mo. 1982) (group health plan policy not an adhesion contract because negotiated by equally strong parties). 
tions. After all, General Motors is no downtrodden consumer, ${ }^{306}$ and in many instances corporate insureds dwarf their insurers in both size and sophistication. ${ }^{307}$

Nevertheless, an assortment of developments in business and insurance which have created a seller's inarket in D \& $\mathrm{O}$ underwriting, ${ }^{308}$ combined with pohicy applications susceptible to insurer inanipulation, has rejuvenated the notion of disparity of bargaining power between insurer and insured.

First, multinationals and mega-congloinerates are no longer the sole chents of $D \& O$ underwriters, as inore and more small and medium-size coinpamies have found it necessary to procure $\mathrm{D} \& \mathrm{O}$ coverage. As noted in Part I, sixty-four percent of all close corporations by 1984 had acquired these policies. ${ }^{309}$ Courts recognize that a corporation is only as capable and sophisticated as its individual personnel. ${ }^{310}$ In $C$ \& $J$ Fertilizer, Inc. v. Allied Mutual Insurance Co. ${ }^{311}$ for example, the plaintiff, a mediuin-size business, successfully argued on unconscionability grounds that a restrictive provision in its mercantile burglary insurance policy was unenforceable. ${ }^{312}$

Second, as the necessity of obtaining $D$ \& $O$ insurance increases, corporate applicants find themselves with correspondingly less bargaining power. The withdrawal of several principal D \& $O$ insurers and the constriction of the reinsurance market has left potential insureds with a

306. Poorer, less sophisticated consumers are the typical beneficiaries of the unconscionability doctrine. See, e.g., Toker v. Westerman, 113 N.J. Super. 452, 274 A.2d 78 (1970) (welfare recipient victimized); Frostifresh Corp. v. Reynoso, 52 Misc. 2d 26, 274 N.Y.S.2d 757 (Dist. Ct. 1966) (nonEnglish speaking welfare recipient victimized), rev'd on other grounds, 54 Misc. 2d 119, 281 N.Y.S.2d 964 (App. Div. 1967).

307. In addition, uulike many types of insurance, no industry-wide standardized form traditionally has existed for D \& O policies. See IVYATT Pol1CY ANALYS1S, supra note 85, at 1. In the past, this has allowed poteutial insureds to "shop around" among coverage regimes, a notion antithetical to a finding of unconscionability.

308. See Heaney, supra note 6, at 54, 56.

309. See supra note 1 .

310. See J. Calamari \& J. Perillo, supra note 303, at 323, 326:

[A] Ithough . . . businessmen are expected to be able to look out for their own iuterests to a far greater extent than consumers, it is equally clear that businesses . . . can be victimized by unconscionable contracts and will receive judicial attention ....

....

... [U]nconscionability may exist . . . even where the oppressor is inexperienced compared to the oppressed.

(footnotes omitted).

311. 227 N.W.2d 169 (Iowa 1975).

312. Id. The policy defined "burglary" as requiring visible marks of forced entry at the exterior of the premises. A theft occurred in which only an interior door of the building was visibly damaged. The trial court had found the policy provision unambiguous and held for the insurer. Id. at 171. The Iowa Supreme Court reversed, holding the other evidence conclusive that a burglary had occurred. Id. at 181. Five of nine justices invoked the doctrines of unconscionability and reasonable expectations in striking the restrictive provision; three of those invoked a theory of implied warranty as well; the four dissenters rejected all three theories. Id. at 182-84. 
significantly restricted choice of coverage regimes. ${ }^{313}$ Those insurers remaiming are now entering negotiations with a "take it or leave it" attitude. Moreover, the breadth and number of exclusions and limiting endorsements being added to $\mathrm{D} \& \mathrm{O}$ pohicies, ${ }^{314}$ combined with the significant premium and deductible increases of recent years, ${ }^{315}$ have made these transactions increasingly resemble adhesion contracts. ${ }^{316}$

Finally, the "harsh commercial setting" faced by corporate applicants when procuring $\mathrm{D} \& \mathrm{O}$ coverage nowadays is no less harsh once the policy is obtained. In today's D \& O hability environment-marked by huge judgments and costly, protracted litigation ${ }^{317}$-it is increasingly true that "[t]he very risks insured against presuppose that if and when a claim is made, the insured will be disabled and in straight financial circumstances and, therefore, particularly vulnerable to oppressive tactics on the part of an economically powerful entity." 318 These oppressive tactics have included the insurers' increasingly liberal exercise of midterm cancellation rights immediately upon learning of a potential claim $^{319}$ and the ultra-aggressive litigation posture insurers have taken to avoid paying clamis once they are made. ${ }^{320}$

313. See supra notes 75-77 and accompanying text.

314. See supra notes 84-93 and accompanying text. The standardization of policy exclusions among $\mathrm{D} \& \mathrm{O}$ carriers is also on the rise, as reinsurers are exerting more control over coverage decisions. 1985 WyATT REPORT, supra note 7, at 21. The preexisting knowledge and exclusion clauses have always been standard policy provisions.

315. See supra notes 78-81 and accompanying text.

316. Although the mere existence of an adhesion contract does not justify a finding of unconscionability, it may provide grounds for further analysis. See Home Federal Sav. \& Loan Ass'n v. Campney, 357 N.W.2d 613, 619 (Iowa 1984).

317. Average defense costs for a D \& O claim in 1984 exceeded $\$ 460,000$. See supra note 18 and accompanying text. Insurers are not obligated to advance payments under the policy to meet these costs. See supra notes 149 and accompanying text; see also Comment, supra note 18, at 691 ("Corporate defense lawyers do not work on contingency, as counsel for stockholder-plaintiffs usually do, and a director may be hard pressed to finance his defense over ycars of complex litigation.").

318. Fletcher v. Western Nat'l Life Ins. Co., 10 Cal. App. 3d 376, 404, 89 Cal. Rptr. 78, 95 (1970).

319. See, e.g., Ipsen, supra note 25, at 231 ("[E]ven a one-year policy is, as one broker says, 'only as good as its cancellation clause. These days, policies are good for 30,60, or 90 days.' "); Victor, $D \& O$ Canceled and Unocal Sues, Legal Times, July 29, 1985, at 1, eol. 2 (Within 24 hours of hearing about a possible hostile takeover bid for Unoeal Corp., that company's primary D \& $O$ carrier exercised its right to cancel coverage without eause; within five weeks, all three excess-layer carriers also served cancellation notices.); $c f$. Gulf Guarantee Life Ins. Co. v. Kelley, 389 So. 2d 920 (Miss. 1980) (life insurer prohibited from exercising 90-day eancellation clause after insured suffered heart attack on grounds that, under such conditions, it would be virtually impossible for insured to procure replacement insurance).

320. See generally supra notes $132-48$ and accompanying text. 


\section{Unconscionable Effects of the Preexisting Knowledge and Exclusion Clauses}

Perhaps the most startling problem with the preexisting knowledge clause is the effect it produces in operation with the exclusion clause immediately following it. As discussed previously, ${ }^{321}$ one plausible interpretation of the phrase "such knowledge and information" in the exclusion clause is that it mcludes any knowledge or information of the act that ultimately gave rise to the claim. Under this interpretation, if any director or officer had such knowledge at the time of the application, regardless of whether she recognized the possiblity of a future claim, then that claim would not be covered. Since it is inconceivable that a meritorious lawsuit could be filed stemming from an act, error, or omission of which no officer or director had knowledge or information, the result of this interpretation would be to exclude coverage of the vast majority of $D$ \& $O$ lawsuits where the cause of action arose before the $D$ \& $O$ insurance application date. ${ }^{322}$

This result is unconscionable for three reasons: (1) it defies the reasonable expectation ${ }^{323}$ of the insured as to the span of coverage secured; (2) it creates a significant gap in the scope of coverage, which goes against public policy; and (3) it eviscerates the insurer's promise to mdemnify, thereby rendering the consideration paid by the insured grossly excessive.

321. See supra Part III, Section B. See also, Shapiro v. American Home Assurance Co., 584 F. Supp. 1245, 1252 (D. Mass. 1984).

322. The insurer may respond by pointing out that even the cost of defending a meritless lawsuit about which no director or officer has any knowledge or information can be quite exorbitant, see supra text accompanying note 18 , and worthy of D \& $O$ insurance coverage.

Even here, however, defendant directors and officers are forced to obtain an unconscionable "double acquittal" in order to win coverage. They inust first be adjudged innocent of the actual charge, and they must also be totally ignorant of its origin. This requirement of a finding of ignorance as well as innocence goes well beyond the requirement for acquittal found in any of the actual policy exclusion provisions.

323. The doctrine of "reasonable expectations" is recognized in most states as an independent ground for refusing enforcement of particular insurance policy provisions. The doctrine:

places substance over form and seeks to avoid frustration of an insured's reasonable expectation as to insurance coverage .... [T] he doctrine applies if ... the insurance policy as issued contains an exclusion which (1) is bizarre or oppressive, (2) eviscerates terms explicitly agreed to, or (3) eliminates the dominant purpose of the transaction.

Carper v. State Farm Mut. Ins. Co., 758 F.2d 337, 340 (8th Cir. 1985) (footnotes omitted). In a growing number of jurisdictions, the doctrine applies to expectations that are objectively reasonable even though a careful study of the policy provisions would have negated those expectations. $R$. KeETON, supra note 304, at 351; see Davenport Peters Co. v. Royal Globe Ins. Co., 490 F. Supp. 286 (D. Mass. 1980). At least 10 states now recognize the doctrine in a "form explicitly going beyond merely resolving aunbiguities against insurers." Id. at 291.

Breach of a reasonable expectation is related to and often is a factor in the determination of unconscionability. However, since the latter doctrine is the broader and more comprehensive of the two, this Counment will apply it in its analysis of the preexisting knowledge clause. 
Steven v. Fidelity \& Casualty Co. ${ }^{324}$ is the seminal California case establishing the court's power to strike down as unconscionable an insurance policy provision that thwarts the reasonable expectation of the insured. In Steven, an air traveler who bought a standardized insurance policy at an airport before his departure was killed when exigent circumstances forced him to fly by air-taxi over part of his route. A provision of the policy, however, stated that coverage for substituted transportation necessitated by imterruption of a scheduled flight was limited to "riding in or on a land conveyance." 325 On that ground the insurer contested the beneficiary's claim to recovery under the policy.

The California Supreme Court refused to give effect to the exclusion clause because, when "hiterally applied, [it] tended toward the harsh and unconscionable." ${ }^{\text {326 }}$ A reasonable person, the court held, when purchasing travel msurance for a whole trip "would nornally expect that if a flight were interrupted by breakdown or other causes, his coverage would apply to substitute transportation for the same fiight." 327 The exclusion provision therefore provided a veritable "trap for the unwary" policy purchaser. ${ }^{328}$

Similarly, the D \& O insured could reasonably expect to receive coverage for any wrongful act not expressly excluded, ${ }^{329}$ regardless of the date, as long as the lawsuit stemming from the act was not actually anticipated by the insured or actually filed by the aggrieved party before the application date.

The Steven court also based its holding of unconscionability on the fact that the hiteral interpretation of the policy would leave a "hiatus in coverage; [tlie insured] bargained for protection for the whole, not part of, the trip." 330 Providing coverage that contains an unexpected gap in the scope of coverage, moreover, is against public policy. In State Farm Mutual Automobile Insurance Company v. Jacober, ${ }^{331}$ the California Supreme Court held an automobile insurer liable for medical costs of the insured injured as a passenger in his car while it was being driven by a pernissive user. The policy defined the "insured" to include the owner and pernissive users of the insured automobile, but the express policy language only covered the "insured" from liability to "other persons." The policy expressly excluded liability coverage for "bodily injury to the

324. 58 Cal. 2d 862, 377 P.2d 284, 27 Cal. Rptr. 172 (1962).

325. Id. at 870,377 P.2d at 289, 27 Cal. Rptr. at 177 (emphasis added).

326. Id. at 878,377 P.2d at 294, 27 Cal. Rptr. at 182.

327. Id. at 869-70, 377 P.2d at 289, 27 Cal. Rptr. at 177.

328. Id. at 879, 377 P.2d at 295, 27 Cal. Rptr. at 183.

329. See supra notes $85-86$ and accompanying text.

330. $58 \mathrm{Cal}$. 2d at 869, 377 P.2d at 288, 27 Cal. Rptr. at 176.

331. 10 Cal. 3d 193, 514 P.2d 953, 110 Cal. Rptr. 1 (1973). 
insured." 332 Notwithstanding this language, the court held that the car owner's injuries were covered by the policy. "[W]e point out that any interpretation which would deny coverage in the cases at hand would create a serious and arbitrary gap in insurance protection.... This result would contravene . . . public policy ...."333

Although the court in Jacober spoke of the public policy behind financial responsibility laws requiring insurance for those using public highways, similar policy considerations exist in the $D$ \& $O$ insurance arena. Those who are injured by the wrongful act of a corporation or its officials should not be demied coinpensation because of an insurance company's insertion of loopholes in the scope of coverage to its insured. Moreover, once the insured corporation has acquired a policy that it expects will provide full coverage, it will assume that it is protected and will make no further effort to acquire more insurance. Gaps in the coverage, where they exist, will go undetected, ultimately resulting in hardship to botli the corporation and the members of the public injured by it.

Other insurance policy cases have held that unreasonably circumscribing the time period of coverage is unconscionable. In Schilk v. Benefit Trust Life Insurance Co. ${ }^{334}$ for example, the court refused to give effect to a clause that provided that benefits under a disability policy were payable ouly when an injury totally disabled the insured within twenty days of the accident. ${ }^{335}$

The insurer further argues that the words "within twenty days from the date of the accident" are so plain and definite that they are not subject to construction. If so, then, the clause involved must be ignored under other well established rules, namely, that when the strict enforcenient of a provision of an insurance pohicy will result im unreasonable and unjust forfeitures or an absurd result, the courts will refuse to enforce the strict meaning of the language of the policy. ${ }^{336}$

Sinilarly, an unjust forfeiture might result if the preexisting knowledge clause were broadly construed to require the disclosure of all acts that possibly could give rise to a D \& O claim. All acts disclosed would be subject to exclusion from coverage, while failure to disclose could result in the voidance of the entire policy. The same forfeiture would result were an objective standard applied to the exclusion clause. Regardless of the disclosure in the preexisting knowledge clause, the

332. Id. at 199, 514 P.2d at 956, 110 Cal. Rptr. at 4 (emphasis omitted).

333. Id. at $205,514 \mathrm{P} .2 \mathrm{~d}$ at $960,110 \mathrm{Cal}$. Rptr. at 8 .

334. 273 Cal. App. 2d 302, 78 Cal. Rptr. 60 (1969).

335. To get around this plain and unambiguous clause, the court devised the "process of nature" rule, holding that a disability is covered by the policy regardless of when it manifests itself, as long as it follows directly from an injury within such time as the process of nature might naturally consume. Id. at 306-07, 78 Cal. Rtpr. at 63.

336. Id. at 307, $78 \mathrm{Cal}$. Rptr. at 64. 
insurer could refuse to cover a claim if any insured knew of its originating act at the date of application.

Finally, a grossly excessive price may also be an element of unconscionability. ${ }^{337}$ Assuming a broad interpretation of the scope of the preexisting knowledge clause or a literal interpretation of the exclusion clause, either of which would result in a wide variety of potential exclusions from coverage, the insurer's promise to indemnify might be found to be illusory, and consequently, the premium paid for that promise excessive. ${ }^{338}$ Similarly, some analysts believe that the panoply of new exclusions appended to D \& O policies, ${ }^{339}$ combined with the insurers' increased willingness to exercise midterm cancellation rights, ${ }^{340}$ strengthen the grounds for arguing that the insurer's promise to indemnify is illusory.

\section{Suggested Interpretation of the Preexisting Knowledge Clause}

Until such time as D \& $O$ insurers and their insureds agree on improvements to the preexisting knowledge clause, litigation involving the allegation of application impropriety is certain to continue. In the meantime, the courts need to establish a defensible interpretation of the preexisting knowledge clause and the perimeters within which it may operate with the exclusion clause to limit D \& O coverage. This Section suggests two paradigms for interpretation. While each has as its goal an equitable result, both are predicated on the idea that the insurer-the drafter of the contract-should not be allowed to use deficient policy language to offset recent adverse developinents in the $\mathrm{D} \& \mathrm{O}$ liability market.

The first paradigm extends traditional insurance contract construction theory to this area. Although courts over the years have proven adept at applying traditional construction theory to effect equitable results in new contractual situations, ${ }^{341}$ they have faltered in applying the traditional theory in the case of the preexisting knowledge clause, ultimately failing to balance the interests of the corporate insured.

337. See, e.g., Patterson v. Walker-Thomas Furniture Co., 277 A.2d 111, 113-14 (D.C. 1971); J. Calamari \& J. Perillo, supra note 303, at 325.

338. The spectacular hikes in premiums and deductibles, see supra notes 78-81 and accompanying text, by themselves probably would not support charges of an unconscionable price term, since they have been made to correct a significantly underpriced rate structure lasting through mid-1984. See supra note 8.

339. See, e.g., 1985 WYATT REPORT, supra note 7, at 22 ("[W]hat is the point of purchasing insurance if every foreseeable cause of loss is excluded?') (remarking at the insurers' growing tendency to exclude claims arising from mergers, acquisitions, tender offers, and going private); see also Olson, The D\& $O$ Insurance Gap: Strategies for Coping, Legal Times, Mar. 3, 1986, at 25, col. 2.

340. See supra note 319.

341. See generally J. CalamaRI \& J. Perillo, supra note 303, at 322-25. 
The second paradigm treats the preexisting illness clause found in most life, health, and hospitalization imsurance policies as analogous to the preexisting knowledge clause. Both clauses, while designed to provide insurers with information directly related to the risk to the insured, request responses that necessarily reflect the judgment of the applicant. Preexisting illness clauses are predominantly construed to be good faith representations, and proof of their breach usually requires an additional determination that the insured was subjectively aware of the seriousness of the illness or infirmity she failed to disclose. By similarly requiring the $\mathrm{D} \& \mathrm{O}$ insurer to prove that the director or officer charged with application misrepresentation actually appreciated the significance of her nondisclosed act, error, or omission, much of the insurer's potential abuse of the application clauses could be eliminated.

\section{Applying Traditional Construction Theory}

Few canons of insurance law are as uniformly recognized and consistently apphed as the doctrine that if a written contract contains a word or phrase capable of two meanings, the enforced interpretation will be that less favorable to the party who drafted the contract and had control over the clioice of words. ${ }^{342}$

If semantically permissible, the contract will be given such construction as will fairly achieve its manifest object of securing indemnity to the insured for the losses to which the insurance relates. Any reasonable doubt as to uncertain language will be resolved against the insurer whether that doubt relates to the party insured against or other relevant matters. ${ }^{343}$

Consequently, different interpretations will apply to coverage clauses and exclusion clauses. While the former are interpreted broadly so as to ensure the greatest possible protection to the insured, the latter are construed narrowly against the insurer. ${ }^{344}$

Moreover, when the deficiencies of an insurance contract provision transcend mere ambiguity, the courts sometimes void the entire provi-

342. See Patterson, The Interpretation and Construction of Contracts, 64 ColuM. L. REV. 833, 854 (1964); G. Couch, supra note 270, § 35:145.

343. Crane v. State Farm Fire \& Casualty Co., 5 Cal. 3d 112, 115, 485 P.2d 1129, 1130, 95 Cal. Rptr. 513, 514 (1971). In Crane, a homeowner's insurer denied coverage of plaintiff's daughter injured while under the care of a babysitter in the babysitter's home, claiming that the policy excluded coverage of any "business pursuits of an Insured, other than activities therein which are ordinarily incident to nonbusiness pursuits ...."Id. The court held that, although in this case babysitting was a business pursuit, the term "ordinarily" defeated the exclusion since home childcare ordinarily is incident to non-business activity. Id. at 116-17, 485 P.2d at 1131, 95 Cal. Rptr. at 515.

344. See, e.g., Mid-Century Ins. Co. v. Hauck, 35 Cal. App. 3d 293, 297, 110 Cal. Rptr. 707, 709 (1973) (term "bodily injury" in a motorboat insurance policy held to cover the death of the insured's wife from a waterskiing fall); State Farm Mut. Auto. Ins. Co. v. Jacober, 10 Cal. 3d 193, 208, 514 P.2d 953, 962, 110 Cal. Rptr. 1, 10 (1973). 
sion. For example, the California Supreme Court noted in Steven $v$. Fidelity \& Casualty $\mathrm{Co}^{345}$ that it has "long been disinclined to effectuate clauses of limitation of liability which are unclear, unexpected, inconspicuous or unconscionable." 346 As discussed earlier in this Part, the preexisting knowledge clause suffers from many of these infirmities. ${ }^{347}$ Nevertheless, despite whatever culpability the D \& O industry harbors as drafters of the problematic clause, it would be overly harsh to strike the clause from the $D \& O$ policy altogether. The information that the clause seeks is important in determining the nature and scope of the risk to be insured.

Short of striking the preexisting knowledge clause from the policy altogether, traditional construction theory would require courts to construe each of the ambiguities against the insurer. The court would interpret the resulting clause as a representation of good faith belief of the applicant that no director or officer had knowledge of an act, error, or omission that he subjectively believed probably would give rise to a lawsuit. As well as adhering to traditional canons of construction, this interpretation is more likely to reflect the insured's reasonable expectations of coverage $^{348}$ and the policy applicant's ability to respond. Additionally, the interpretation minimizes any confusion that a broader reading might cause about the materiality of elicited responses or omissions. ${ }^{349}$

Resolving the ambiguities in the preexisting knowledge clause also helps clarify certain aspects of its vagueness. Since the response to the clause is held to be a representation, the good faith belief of the applicant himself, or an inquiry of limited scope directed to other insureds, probably would suffice. ${ }^{350}$ Also, the interpretation of "might" as "probably

345. 58 Cal. 2d 862, 377 P.2d 284, 27 Cal. Rptr. 172 (1962).

346. Id. at 879,377 P.2d at 295,27 Cal. Rptr. at 183 .

347. See supra notes $249-340$ and accompanying text.

348. If the preexisting knowledge clause was intended solely to elicit information with which the insurer could evaluate overall insurability potential, the interpretation "probably would" might be too narrow a construction to be within reasonable expectations of the insured. However, when the clause is coupled with the exclusion clause which operates to avoid coverage of any and all claims identified by the preexisting knowledge clause, the interpretation "probably would" seems more likely to refiect the insured's expectations. A policy excluding coverage of any act that possibly could give rise to a claim is distinctly counter to the expectations of an insured paying top premium dollars.

349. It is questionable whether information of an act, error, or omission that possibly could give rise to a D \& O claim would be material-allowing an insurer's rescission if the information were misrepresented. In life and health insurance policies, for example, information of minor illnesses or indispositions suffered by the applicant is not material. See infra notes $357-63$ and accompanying text.

350. Conversely, were the clause held to require a warranted response, the expected scope of inquiry undertaken by the applicant would be fairly broad in order to protect the insureds from having coverage withdrawn. Also, the agency question would in effect be resolved in favor of finding each director and officcr to be the agent for each of the others, since failure to disclose requested information would result in the policy's being declared void. 
will" significantly narrows the universe of acts, errors, or omissions required to be disclosed $i m$ the apphication, thus decreasing that aspect of the clause's vagueness. However, neither construing the clause as a representation, nor "might" as "probably will," affects the question of whether an agency relationship binds the apphicant to the other insureds or the insureds to each other.

\section{Adopting the Standard for Breach of the Preexisting Illness Clause}

Guidance for interpretation of the preexisting knowledge clause may be found in the judicial construction of an analogous application provision in life and health insurance contracts. Most hfe and health insurance policies inquire of the apphicant, "Do you know of any impairment, disease or disorder existing in your health or physical condition?"351 This provision, whicl shall be referred to as the preexisting illness clause, generally follows a series of interrogatories inquiring about previous illnesses or injuries no longer manifest, past periods of hospitalization, and other medical treatinent. ${ }^{352}$ The clause and interrogatories both assist the insurer in assessing the risk potential of the apphicant and provide the basis for stipulating exceptions to coverage under the policy. ${ }^{353}$

Similarly, the interrogatories preceding the preexisting knowledge clause on the $\mathrm{D} \& \mathrm{O}$ apphication request, among other things, information of past or pending lawsuits against any of the proposed insureds. ${ }^{354}$ The clause then asks for information about present knowledge of an act, error, or oinission that may im the future result in hitigation against an insured. This niformation is similar to information of an existing illness in that both itens have the potential to impose liability on the insurerthe illness, by worserning until it causes the insured's disability, hospitalization or death, and the act, error, or omission, by giving rise to a lawsuit.

While many life and health insurance carriers have atteinpted to construe the preexisting illness clause as a warranty of fact, the courts generally have held it instead to be a representation of good faith belief. ${ }^{355}$

351. Friez v. National Old Line Ins. Co., 703 F.2d 1093, 1094 (9th Cir. 1983) (life insurance policy); see also G. Couch, supra note 270, § 37:97.

352. G. Couch, supra note 270 , $\S \S 37: 96-282$.

353. Id. § 37:96; see also W. VANCE, supra note 305 , at 364-66 (discussing the need to ascertain and control risk and loss).

354. M. SCHAEFTLER, supra note 30, at 275.

355. See, e.g., Friez v. National Old Line Ins. Co., 703 F.2d 1093, 1095 (9th Cir. 1983); Sommer v. Guardian Life Ins. Co., 281 N.Y. 508, 514-15, 24 N.E.2d 308, 311 (1939) ("Even statements of good health or freedom from disease which are made in the form of a warranty are usually construed merely as representations and statements of opinion, since it is plain that the insured or applicant cannot speak with positive knowledge."); J. DOBBYN, INSURANCE LAW 154 (1981); G. RICHARDS, RichardS ON THE LAW OF INSURANCE $\S \S 312-313$ (W. Freedman 5th ed. 1952 \& Supp. 1968). 
More importantly, when ruling on the alleged breach of a preexisting illness clause, the courts have generally added to the requirements that the applicant's representation be false and material, a further requirement that the applicant knew and appreciated the significance of the omitted information. ${ }^{356}$ Whereas inateriality is grounded in the insurer's subjective perception of the omission's effect on risk evaluation, this latter requirement is grounded in the insured's subjective perception of the omission's significance. The extra requirement, therefore, adds balance to the judicial accounting of the parties' expectations.

Thompson v. Occidental Life Insurance Co. ${ }^{357}$ illustrates how courts interpret the preexisting illness clause. Thompson had applied for a $\$ 100,000$ life insurance policy and had been examined by the insurer's physician. On receipt of the application, the insurer decided to require an additional medical examination, but, before Thompson was informed of that decision, he was fatally imjured in a bathtub fall. ${ }^{358}$ The insurer notified his beneficiary that it would neither issue nor make payments under the policy, contending that even if an insurance contract had been formed, application misrepresentation concerning Thompson's medical history rendered it unenforceable. Specifically, in response to questions about past "disease[s], condition[s] or disorder[s]," Thompson had failed to report approximately ten medical consultations held at a hospital with five different doctors, during which he discussed a variety of maladies, including chest and leg pains and circulatory problems. ${ }^{359}$ These consultations commenced two months before and ended only the day before the insurance medical examination took place. The court, while acknowledging that an msurer has a right to know all that the insurance applicant knows regarding the state of his health, nevertheless ruled:

[I] the applicant for insurance ... failed to appreciate the significance of information related to him, his incorrect or incomplete responses would not constitute grounds for rescission. ... Moreover, "Questions concerning illness or disease do not relate to minor indispositions but are to be construed as referring to serious ailments which undermine the general health." [Citations] $]^{360}$

Consequently, the court rejected the insurer's grounds for forfeiting the contract and awarded Thompson's beneficiary the full $\$ 200,000$ double indemnity provided for under the policy. ${ }^{361}$

356. See infra text accompanying notes 357-63.

357. 9 Cal. 3d 904, 513 P.2d 353, 109 Cal. Rptr. 473 (1973).

358. Id. at 909, 513 P.2d at 355, 109 Cal. Rptr. at 475.

359. Id. at 915, 513 P.2d at 359-60, 109 Cal. Rptr. at 479-80.

360. Id. at 916, 513 P.2d at 364, 109 Cal. Rptr. at 480 (emphasis added). But see The Supreme Court of California 1972-1973, 62 CALIF. L. REv. 309, 487-95 (1974) (arguing that Thompson's omissions were clearly material and that the court improperly abrogated the insured's duty of fair dealing).

361. Thompson, 9 Cal. 3d at 921, 513 P.2d at 364, 109 Cal. Rptr. at 484. 
Similarly, in Travelers Insurance Co. v. Byers, ${ }^{362}$ the court held that even if the insured was afflicted with a serious disease at the time of his application, unless he knew of the disease, willfully omitted it, and recognized its severity, the omission could not furnish the ground for rescission. "The word 'illness' as used in a question ... as to whether or not an applicant had ever had any illness ... 'relates to matters which have a sensible appreciable forn1, ... [are] of a substantial character and not ... speedily forgotten." " 363

Applying these principles in the D \& $\mathrm{O}$ insurance context, a court probably would not find it reasonable to require the $\mathrm{D} \& \mathrm{O}$ applicant to provide information of literally any act, error, or omission with the potential to cause litigation. Rather, the clause would be held to require information concerning only those occurrences that are of a "substantial character," and "not speedily forgotten."

The "good health" clause in most life insurance policies is a separate provision closely analogous to the exclusion clause in $D \& O$ policies. The good health clause stipulates that hability of the insurer shall not arise under the policy unless, at the time the policy is delivered and the first premiun 1 paid, the insured is in good health. ${ }^{364}$ In effect, the good health clause provides an independent ground upon which the insurer conld nove to rescind the policy, should it discover any existing illness or condition not expressed in the preexisting illness clause. ${ }^{365}$ Similarly, under the $\mathrm{D} \& \mathrm{O}$ policy exclusion clause, any claim arising fron $\mathrm{an}$ act, error, or omission known but not disclosed on the application would be denied coverage.

There is some judicial support for treating a good health clause in life insurance pohicies as a warranty, despite acknowledgment that a representation standard is appropriate for the preexisting illness clause. ${ }^{366}$ In American National Insurance Co. $v$. Herrera, ${ }^{367}$ the court distinguished between those two provisions in a family health insurance policy, holding the policy's good health clause to be a condition precedent to the insurer's liability. In Herrera, the applicant for the policy answered "No" to the preexisting illness clause, "Do any of the persons to be included have plyysical or mental defects?" It later turned out that the applicant's wife was not in sound health when the policies were issued. The insurer filed to rescind, and the court granted the rescission, even

362. 123 Cal. App. 473, 11 P.2d 444 (1932) (autopsy following insured's death from a fall five months after policy issuance revealed existence of serious chronic kidney disease).

363. Id. at 478, 11 P.2d at 446 (quoting Poole v. Grand Circle, Women of Woodcraft, $18 \mathrm{Cal}$. App. 457, 459, 123 P. 349, 150 (1912) (emphasis supplied)).

364. See W. VANCE, supra note 305 , at 640.

365. Id.

366. Id. at $640-43$.

367. 211 Cal. App. 2d 793, 27 Cal. Rptr. 641 (1963). 
though no fraud on the part of any of the insureds was proven. ${ }^{368}$ The court held:

There is a basic difference between the insurer's defense against liability based upon an alleged misrepresentation respecting the applicant's state of health and its defense which rests upon a sound-health provision in its contract; the former is concerned with the scope of the representation made which, in turn, is dependent upon the knowledge of the person making it, whereas the latter is concerned with the scope of a condition precedent to hability which is determined by the language of the contract; thus, although proof of lack of knowledge may eliminate a factor essential to a charge of misrepresentation, as heretofore noted, it is immaterial to an issue respecting the effect of the condition precedent. ${ }^{369}$

Relying on the analogy between the $\mathrm{D} \& \mathrm{O}$ exclusion clause and the life insurance good health clause, the D \& O insurer inay argue that a particular claim should be excluded pursuant to the objective operation of the exclusion clause, notwithstanding the applicant's good faith answer to the preexisting knowledge clause. ${ }^{370}$

Insureds have two possible rebuttals to this argument. First, although Herrera and other opinions have held that a sound health clause is a condition precedent, and therefore a warranty, numerous courts have ruled that the clause is no different from the preexisting illness clause; it too requires proof of the insured's knowing misrepresentation before the insurer can escape liabihity. The California Supreme Court, for example, has held:

[A] "good health" provision does not bar recovery under the policy where the applicant believes in good faith that his health has not materially changed between the time of application for the policy and its delivery, and that it is the insured's own knowledge of the state of his health which is decisive rather than the uncommumicated knowledge of a third person. $^{371}$

Second, even if the exclusion clause in the $\mathrm{D} \& \mathrm{O}$ policy is construed

368. Id. at 804, 27 Cal. Rptr. at 648-49; see also Beck v. Connecticut Gen. Life Ins. Co., 456 F.2d 1040 (5th Cir. 1972), cert. denied 409 U.S. 845 (1972) (good health clause upheld as valid condition precedent to coverage).

369. Id. (footnotes omitted).

370. This was the position taken by Judge Keeton in Shapiro v. American Home Assurance Co., 584 F. Supp. 1245, 1252 (D. Mass. 1984).

371. Harte v. United Benefit Life Ins. Co., 66 Cal. 2d 148, 152, 424 P.2d 329, 331, 56 Cal. Rptr. 889, 891 (1967); see also Metropolitan Life Ins. Co. v. Devore, 66 Cal. 2d 129, 138, 424 P.2d 321, 326, 56 Cal. Rptr. 881, 886 (1967) ("[I]t would be unfair to hold a policy void where an insured had complied with every provision of the contract merely because lurking undetected within his anatomy was some pathology which would in the future prove fatal."); Sharp v. Richmond Life Ins. Co., 183 S.E.2d 132, 135 (Va. 1971) ("sound health" clause construed as an exclusion from preexisting conditions about which insured knew or should have known, rather than as a forfeiture). As a general rule, "[c]ourts are disinclined to construe the stipulations of a contract as conditions precedent, unless compelled by the language of the contract plainly expressed." Brubaker $v$. Beneficial Standard Life Ins. Co., 130 Cal. App. 2d 340, 347, 278 P.2d 966, 969 (1955). 
as a condition precedent, by its very language it ties itself back to the "fraud" standard of proof of the preexisting knowledge clause. Under the exclusion clause, any objective existence of "such knowledge or information" operates automatically to block coverage. But "such" refers to that type of knowledge or information described in the preexisting knowledge clause. Because the two clauses are thus linked, the standard required to prove breach of the exclusion clause should be the same standard applied to the preexisting knowledge clause: falsity, materiality, intent to deceive, aud the insured's appreciation of the siguificance of the information.

\section{IV}

\section{ALTERNATIVES}

There are at least three alternatives to the insurer's current use of the preexisting knowledge clause as a means of obtaining information necessary to evaluate an applicant's insurance risk and flesli out potential coverage exclusions.

\section{A. The Checklist}

First, in lieu of a single, open-ended request for preexisting knowledge of "acts, errors, or omissions," the application could einploy a checklist of types and categories of acts, errors, and omissions that the imsurer feels might lead to a claim under the policy.

Some D \& O underwriters already liave begun to expand the list of interrogatories preceding the preexisting knowledge clause which solicit factual data about the corporation. For example, one application asks whether, in the past three years, management has rejected any stockholder-submitted proxy statement proposal, whether there has been any change in key management, whether the corporation lias changed auditing firms, and whether anyone has offered or negotiated to purchase five percent or more of the company stock. ${ }^{372}$ This expanded questiomiaire aids the insurer by increasing both the accuracy and accountability of the data used to evaluate insurability. While producing a more complete picture of the corporate entity, it allows the insurer to steer its investigation directly to those transactions and events known to be susceptible to litigation. ${ }^{373}$ Moreover, by supplementing its inquiry with directed ques-

372. St. Paul Fire and Marine Insurance Company, Directors' and Officers' LiabilityCorporate Form, reprinted in M. SCHAEFTLER, supra note 30, at 289-92.

373. For example, some form of risk-value quotient might be assigned to such objective acts as disapproving a friendly takeover offer, see supra note 23 and accompanying text, or implementing an employee stock option plan. Just as life and health insurers rely extensively on actuarial data in making risk judgments, so too $D \& O$ insurers have at their disposal a significant and rapidly growing body of data assessing D \& $O$ claims and their sources compiled by risk analysts such as the Wyatt Company, see supra note 1, and Marsh \& McLennan. 
tions the insurer benefits from the legal presumption that responses to specific factual questions on an insurance application generally will be deemed material as a matter of law. ${ }^{374}$

The preexisting knowledge clause, however, seeks a different class of information than do the interrogatories preceding it, and therefore requires a somewhat different checklist. Contrast the information that at its July meeting the board adopted a poison pill resolution, with the information that at its July meeting the board forgot to examine a report prepared by outside counsel on the poison pill measure. While the former information might induce the insurer to investigate further the dynamics of the action, it is the latter that would actually constitute an act, error, or omission with lawsuit potential. While the insurer could not hope to avoid all coverage of transactions or events disclosed in response to the interrogatories, it reasonably could exclude claims arising from disclosed acts which appear negligent or wrongful on their face.

Thus, the checklist would concentrate on examples of negligent or otherwise wrongful conduct on the part of an officer or director which might give rise to a claim. The list might include absence from meetings, failure to protest inaccurate minutes or record dissent from wrongful acts of the board, illegal or ultra vires acts, failure to seek adequate outside consultation before voting, and other acts that courts have held violate the duty of due care im corporate decisionmaking.

The central problem with drafting such a checklist is the difficulty in making it coinprehensive without its becoming onerously long. Indeed, no list could recite, im a vacuum, every conceivable form of director and officer negligence or wrongdoing. On the other hand, the formidable list of express exclusions already contamed in the D \& O policy-including acts done for personal profit, adjudged dishonest or criminal acts, libel or slander, Section $16(\mathrm{~b})$ violations, ERISA violations, etc. ${ }^{375}$-narrows the range of inquiry of the checklist. Moreover, life and health insurance policies, which traditionally have presented in checklist form the entire

374. See G. Couch, supra note 270, § 35:140; see also Snare \& Triest Co. v. St. Paul Fire \& Marine Ins. Co., 258 F. 425, 427 (2d Cir. 1919); Pierre v. Metropolitan Life Ins. Co., 22 Cal. App. 2d 346, 348-49, 70 P.2d 985, 986 (1937). Judge Keeton applied this axiom to the preexisting knowledge clause in Shapiro v. American Home Assurance Co., 584 F. Supp. 1245, 1250 (D. Mass. 1984).

Yet, expanding the list of factual interrogatories, by itself, will not benefit an insured faced with responding to the preexisting knowledge clause, unless the interrogatory responses are incorporated into the clause. For example, the applicant could be queried whether any director or officer has knowledge of an act, error, or omission which might give rise to a claim as to each event identified in response to the interrogatories. Of course, no list is absolutely complete, and a general question asking for other known facts would necessarily follow.

375. The exclusions contained in National Union's $D$ \& $O$ policy can be found in $M$. SCHAEFTLER, supra note 30 , at 281-82. 
litany of potential diseases, illnesses, afflictions, and conditions, ${ }^{376}$ create a high-water mark for exhaustiveness that a $D$ \& $O$ policy application would be hard-pressed to reach.

Ultimately, the checklist could not operate with draconian rigidity, allowing the insurer to exclude only those acts, errors, or omissions revealed in response to specific checklist recitals, while relieving the insured from disclosing any knowledge of lawsuit-inducing acts not so identified. Ratler, the purpose of the cliecklist would be to guide and inform the insured as to the types of information the insurer is seeking in response to the preexisting knowledge clause. Nevertheless, the cliecklist will streamline dispute resolution. To the extent that an undisclosed act, later producing a D \& O claim, was specifically mentioned in the checklist, the insurer can more easily prove both that the nondisclosure was material and that the reasonable expectations of the insured would not be violated by noncoverage. Conversely, to the extent the insured's undisclosed act was completely unrelated to the checklist recitals, the insured could parry the insurer's effort to void coverage. In either case, the checklist ameliorates the vagueness regarding the scope of inquiry of the preexisting knowledge clause as currently written.

\section{B. Separate Checks}

A second change to the apphication format could require separate preexisting knowledge queries to be distributed to each director and officer insured under the policy. Each insured individual would be required to execute a stateinent to the effect that to the best of her knowledge, she is cognizant of no act, error or omission which she has reason to beheve provides grounds for any future claim. Preferably, each statement would incorporate a checklist approach described above, to assist the individual in responding accurately and comprehensively.

Each statement would bind only its signator. Failure by one insured to disclose material information miglit result in a disallowance of coverage as to ler, but would not affect the rights of the otlier insureds. This approach has the benefit of protecting innocent directors and officers against rescission of the $D \& O$ policy when their agent is at fault, since "their own statements eliminate both dependence on their agent and on one anotlier's representations and actions." 377

While insurers no doubt would appreciate the higher degree of trustworthiness of information obtained directly from individual insureds, they are equally likely to dislike the notion of severability of the insur-

376. See, e.g., G. Couch, supra note $270, \$ \$ 37: 166-37: 256$ (analyzing 78 "specific diseases and conditions"-from "alcoholism" to "venereal disease"-about which health insurance policies traditionally inquire).

377. M. SCHAEFTLER, supra note 30 , at 171 . 
ance contract. First, the insurer may resist on the ground that the risk evaluated and underwitten was unitary; it extended to the corporation as a whole, including its directors and officers as a group. ${ }^{378}$ Second, since all directors potentially may be held jointly and severally liable for the wrongdoing committed by any one, ${ }^{379}$ relieving the insurer of liability only for the acts of the single director who makes a misrepresentation may save the insurer absolutely nothing. The consideration paid for the policy under a severability regime would most likely need to be increased significantly.

From the corporation's perspective, too, there are drawbacks to requiring each director and officer desiring coverage under the policy to tender separate responses to the preexisting knowledge question. First, to the extent that the question employs an exhaustive list of interrogatories cataloguing possible negligent acts and identifying transactions susceptible to lawsuit, requiring individual inquiries of each director and officer is considerably more onerous and time-consuming than reliance upon a single agent. ${ }^{380}$ The inquisition-like nature of such an inquiry may also cause dissension within the directorate, especially among outside directors, who already feel they are under the magnifying glass. ${ }^{381}$

Second, in today's strained and volatile D \& O market, to the extent an individual director or officer lists any lawsuit-inducing act, the insurance company is likely to exclude her, either just from coverage of claims arising from the listed act or-if it deems her a generally "bad risk"from coverage under the policy altogether. The result would be that some, but not all, officials will enjoy coverage. Not surprisingly, the corporation may have immense difficulty finding an alternate insurance underwriter to fill the holes. ${ }^{382}$ Moreover, uneven coverage of board members creates its own problems: In addition to placing a general damper on morale, in certain transactions it may produce a decisionmaking rift among members possessing disparate levels of risk exposure.

Third, the threat of noncoverage resulting from any disclosure of negligent acts on the application creates a powerful disincentive to disclose. Common sense would dictate that rather than volunteer information which would result in immediate noncoverage, it would be better to

378. See, e.g., Bird v. Penn Central Co., 341 F. Supp. 291, 295-96 (E.D. Pa. 1972); Prudential Ins. Co. v. Anaya, 78 N.M. 101, 106, 428 P.2d 640, 645 (1967).

379. See Shapiro v. American Home Assurance Co., 584 F. Supp. 1245, 1253 (D. Mass. 1984).

380. It is not uncommon for a corporation to include a large number of directors and officers under a single $\mathrm{D} \& \mathrm{O}$ policy. Penn Central, for example, had more than sixty officials insured at the time its policy was rescinded. See Bird, 341 F. Supp. at 294.

381. See, e.g., Comment, Corporate Indemnification: A View from the Director's Chair, 27 LoY. L. REV. 89, 91-97 (1981).

382. See supra Part I, Section B(1). 
wait and see if an actual lawsuit does arise from the act, and then require the insurer to prove the applicant knew about it. At worst, the applicant would then be in the same boat in which he would have placed himself by disclosing. ${ }^{383}$

Finally, despite a promise of confidentiality expressed in the application, the damage wrought should an officer's or director's admission of negligence fall into the wrong hands (for example, any shareholder's) is substantial enough to warrant great trepidation among corporate officials-just the opposite effect which $\mathrm{D} \& \mathrm{O}$ coverage was meant to produce.

Even if the corporate insured is unable to convince the insurer to use individual responses to the preexisting knowledge clause it nevertheless should seek inclusion in the pohcy of a "severability and nonimiputation" provision. Under such a clause, the apphication should be construed as a separate proposal for coverage for each insured person. Neither the misstatement of the apphication signator nor the nondisclosed preexisting knowledge of any nonsignator would be imputed to the other "innocent" insureds so as to defeat the latter's coverage. ${ }^{384}$

\section{Passing the Baton}

Third, the underwriter could require, as a precondition of issuing the D \& O policy, a separate opimion letter by legal counsel to the corporate apphicant, as to the existence or nonexistence of "preexisting knowledge," as well as to other insurability issues. Opimion letters have become in recent years a standard documentary component of most large corporate transactions, including financings, sales of businesses, equipinent leases and chattel inortgages, 1nergers and acquisitions, and public and private securities transactions. ${ }^{385}$ Although the purchase of an insurance policy traditionally has not held the saine status as these other transactions, this Comment has attempted to illustrate that the corporate manager who fails to devote adequate attention and resources to the execution of a $D \& O$ contract runs unacceptably high risks. With the for-

383. See Bird, 334 F. Supp. at 258.

384. As of 1984, two D \& O polices-the "CNA Mini" and the "Federal" policies-had incorporated these clauses. Three other polices-the "CNA ACCO," "First State" and "Royal"had inserted a limited nonimputation clause, similar to the one pioneered by Lloyd's on its 1978 Lydando No. 1 form. That clause acts to protect innocent directors and officers from having imputed to them knowledge of a nonsigning officer or director, but expressly does not protect them from the misstatements or omissions of the application signator. See WYATT POLICY ANALYSIS, supra note 85 , at 23 . This limited nonimputation clause is intended as a compromise between the expectations of the insurer and the innocent corporate officials. See Hinsey, supra note 152, at 1976.

385. See Fuld, Legal Opinions in Business Transactions-An Attempt to Bring Some Order out of Some Chaos, 28 Bus. LAw. 915, 915 (1973) ("Many clients and lawyers believe that, next to the conveyancing instruments, the legal opinions are the most important papers delivered at the closing."). 
midable price-tags now attached to these policies, the potential for unlimited hability that the policies are supposed to deflect, and the complexity of the issues mvolved in current coverage disputes, the purchaser of $\mathrm{D} \& \mathrm{O}$ insurance today should rank that transaction as one of the most important on the corporate agenda.

The concept of requiring an opinion letter before issuing a $D \& O$ policy has a foundation in procedures employed in other types of insurance underwriting. The due diligence investigation that would preeede the opinion letter is directly analogous to the physical examination performed by a physician as a prerequisite to issuing a health or life insurance poticy. A physician, regardless of whether she is selected by the applicant or the insurer, lends to the insurability evaluation both a degree of professional expertise not commonly possessed by either party and a degree of objectivity that neither party can be counted upon to provide. The same can be said of the legal counsel responsible for producing the opinion letter, although under current practice such counsel is almost always selected by the corporation under review.

At least three advantages can be gained from opinion letters. First, they will provide more accurate and trustworthy information. As noted earher, one of the biggest problems with the preexisting knowledge clause is the difficulty in anticipating the disparate variety of occurrences from which a claim under the policy might arise. ${ }^{386}$ A corporate attorney has more knowledge of the current and evolving theories of $\mathrm{D} \& \mathrm{O}$ liability, and legislative and judicial trends in that area, than the average corporate officer or director. ${ }^{387}$ Although inost of the largest corporations currently employ risk management personnel, with expertise at least comparable to legal counsel, many others, especially close corporations, do not. These latter companies stand to benefit most from the legal imprimatur an opinion letter would provide. Moreover, Smith $v$. Van Gorkom, ${ }^{388}$ Hanson Trust PLC v. ML SCM Acquisition, Inc. ${ }^{389}$ and their progeny clearly indicate the courts' increasing preference that corporate officials utilize outside expert advisory opinions in their decisionınaking procedures. ${ }^{390}$

Second, use of an opinion letter would significantly clarify the allo-

386. See supra notes $250-54$ and accompanying text.

387. Corporate counsel is often called upon to provide in a comfort letter an "express negative assurance" that it "knows of no material pending or threatened litigation against the Company." See Babb, Barnes, Gordon \& Kjellenberg, Legal Opinions to Third Parties in Corporate Transactions, 32 Bus. LAw. 553, 561-62 (1977) (describing proper due diligence review prior to issuing express negative assurance). Negative assurances as to occurrences that might give rise to litigation, of course, would be more speculative.

388. 488 A.2d 858, 877-78 (Del. 1985); see supra notes $33-40$ and accompanying text.

389. 781 F.2d 264, 275 (2d Cir. 1986); see supra notes $41-47$ and accompanying text.

390. See Lesser, supra note 44 , at 22 , col. 3-4. 
cation of risk in the insurance transaction. Presented with two relatively "innocent" parties, the courts often have had to resort to legal fictions to allocate blame: The insurer gets stuck because it did not draft a better provision or the outside director gets stuck because the dark secrets of her agent are imputed to her. With an opinion letter certifying the information on the application, the risk of neghigent misstatements is shifted to a third party: the corporate counsel. ${ }^{391}$ An opinion letter would not only contribute to a more accurate and rehable application, which in turn should reduce the number of disputes reaching hitigation, it would also provide the court with a better road map for lawsuit adjudication.

Third, as a side benefit, the use of an opinion letter would increase the confidentiality of the information disclosed in procuring $D \& O$ coverage since involving a lawyer in the process brings into operation attorney-chent and work product protections. ${ }^{392}$ Confidentiahity of information that an insured discloses to its insurers, though soinetimes granted by the court, is not otherwise guaranteed. ${ }^{393}$

Requiring a legal opimion letter, preceded by a due diligence investigation, also has some drawbacks. First, it will significantly add to the expense and time required to procure $\mathrm{D} \& \mathrm{O}$ coverage. Nevertheless, although the price tag of a due diligence examination a decade ago would possibly have exceeded the cost of the entire $D \& O$ premium, today this rarely will be the case. Moreover, most corporations that regularly file registration stateinents with the SEC already employ director and officer questionnaires designed by corporate counsel to update periodically inforination contained in certain sections of the registration statements. ${ }^{394}$ For these compaines, it would be a relatively simple inatter to supplement the questiormaires with questions regarding each director's or officer's knowledge of potential claim-producing acts.

A second concern is the extent to which legal counsel issuing the coinfort letter will be liable for application inisstatements. ${ }^{395}$ Inserting

391. To the extent that counsel reasonably relies on fraudulent statements concerning an individual director's or officer's preexisting knowledge, the risk shifts back to the insureds, through the operation of indemnification and contribution rules. See A. JACOBS, OPINION LETTERS IN SECURITIES MATTERS, Intro.-40-Intro.-45 (rev. 1985).

392. See Solovy, Africk \& Lehker, Attorney-Client Privilege and Work Product Problems in Reporting to the Carrier, in The Crisis IN Directors and OfFICERs Liability INSURANCE 249 (D. Block \& A. Driver eds. 1986).

393. Compare State ex rel. Cain v. Barker, 540 S.W.2d 50, 53 (Mo. 1976) (upholding a broad insurer-insured privilege), with Gottlieb v. Bresler, 24 F.R.D. 371,372 (D.D.C. 1959) ("[A] communication received by a liability insurance company from . . . its insured . . . is not a privileged communication. It is not in the same class as a communication to an attorney.").

394. See, e.g., SEC Form S-1 Item 11(m), which requires disclosure of "certain relationships and related transactions" between the corporation and management, 17 C.F.R. 229.404 (1986). The information solicited by questionnaire for this and other sections of the Form S-1 is similar to that which would be relevant to a preexisting knowledge inquiry.

395. Generally, a negligence standard applies to attorneys issuing opinion letters. See Note, 
another party into the coverage dispute inay provide the insurer and insured with a scapegoat upon whom to deflect the entire cost of the disputed coverage claim. ${ }^{396}$

Third, the preexisting knowledge clause requests information which, in essence, reflects the applicant's state of mind. Despite a thorough review of every corporate record and docuinent, ultimately legal counsel's opimion as to preexisting knowledge can be grounded no deeper than in the good faith disclosure of each individual director or officer. ${ }^{397}$

Finally, whereas under the status quo, the preexisting knowledge clause stands a good chance of being interpreted as requiring no more than a good faith response, once an opimion letter is issued, that response in effect inay be elevated to the status of a warranty. If so, depending upon the extent to which laws of agency are applied, any inisstatement could result in coverage being voided altogether for one or more of the insureds.

\section{CONCLUSION}

Ultimately, no ainount of clarification or revision of the D \& O policy or apphication can eliminate coverage disputes arising between insurers and their corporate insureds. As Part I of this Comment indicates, the genesis of the $\mathrm{D} \& \mathrm{O}$ insurance crisis hes in a coinbination of forces and tensions that are not easily reconciled. Furthermore, the D \& O crisis itself is but one coinponent of the larger liability insurance crisis affecting American society. ${ }^{398}$ Although this Coininent has suggested ineasures to inprove the $\mathrm{D} \& \mathrm{O}$ insurance contract and thereby reduce future disputes, resolution of the overall crisis will require "focus[ing] on the quilt and not the legal patches."399

Attorney Malpractice, 63 CoLuM. L. REV. 1292 (1963). An attorney's liability for an erroneous opinion, however, "is generally not limited to the size of the error," but may reach the full extent of the losses caused by it. A. JACOBS, supra note 391, at Intro.-44-Intro.-45. On the other hand, an attorney's legal malpractice insurance should cover liability for opinion letters as for other liabilities incurred in the practice of law. See Fuld, supra note 385 , at 918 n.3.

396. See, e.g., Sharp v. Coopers \& Lybrand, 649 F.2d 175 (3d Cir. 1981) (accounting firm liable for employees' reckless issuance of flawed corporate opinion letter).

397. See supra note 391.

398. See, e.g., Jackson, Proposals to Curb Damage Awards in Lawsuits Lead to Flood of Lobbying Efforts on Both Sides, Wall St. J., April 9, 1986, at 64, col. 1.

399. Oesterle, supra note 105 , at 517.

Numerous legislative proposals offering both broad and narrow reform have been introduced at the state and federal levels. Most proposals center on curbing the number and size of tort damage awards. They include eliminating or restricting the rule of joint and several liability, which allows a plaintiff to collect full damages from a negligent party even if the courts find that party only partly at fault; placing a ceiling on the amount of punitive and other noneconomic damage awards; capping the amount of plaintiffs' attorneys' fees; and setting into place extra hurdles to proving liability, especially in product liability and punitive damages actions. See Jackson, supra note 398; Waldman \& White, Battle Rages Over Damages, Insurance Rates, Wall St. J., April 15, 1986, at 6, col. 1; 
Whether or not the D \& O insurance crisis will be calmed by concerted legislative and judicial attention, or by the equally inscrutable forces of time and the free-inarket econoiny, D \& O insurers and insureds alike are consigned to ride out the remainder of the storm. Although the risk which they contracted to distribute between them has grown onerous and unforeseen, both parties inust continue their bargain in good faith. While insureds cannot be reheved of their duties of honest disclosure, neither should insurance compamies atteinpt to redistribute the risk ex post through the nianipulation of unclear policy provisions. The preexisting knowledge clause is one such provision susceptible to insurer abuse. Until such time as both parties fashion a nore reliable alternative to the clause, the courts should take a jaundiced view toward nisurers' reliance upon it to avoid coverage.

\section{William Caraccio*}

Wermiel, Crisis in Liability Insurance Is Creating Mounting Pressure for New Legislation, Wall St. J., April 9, 1986, at 62, col. 1. Other legislative measures are aimed at the insurance industry itself, including requiring more accountability and disclosure by insurers in deriving premium rates and cancelling policies, subjecting the industry to antitrust regulation, and actually forcing rate decreases in the event other tort-reform bills pass. See Waldman \& White, supra.

Within the corporate D \& $O$ hability arena, too, moves are underway to break the spiral of increasing costs and dwindling availability of $\mathrm{D} \& \mathrm{O}$ coverage. The American Law Institute, for example, has drafted a proposal which would impose a ceiling on an individual director's liability for negligence by tying any damage award to the value of compensation received from the corporation for annual services performed. See American Law InstTtute, Principles of Corporate Governance: ANalysis and Recommendations, Discussion Draft No. 1 221-22 (1985). Indiana recently enacted a statute allowing corporations to indennify directors and officers against derivative suit liability for duty of care violations other than willful or reckless misconduct. IND. CODE 23-1-35 § 1(e)(2) (effective April 1, 1986); see also Victor, Statutory Response to $D \& O$ Crisis Studied, Legal Times, March 13, 1986, at 1, col. 2 (changes in Delaware law also contemplated). Corporations themselves are examining measures to arrest this surge in $\mathrm{D} \& \mathrm{O}$ liability, including, among other things, ex ante waivers of the corporation's right to sue its officials for misconduct, see Oesterle, supra note 105 , at 553-55, and limiting hability through charter amendment; see supra notes 118-23 and accompanying text.

* A.B 1981, University of California, Irvine; third-year student, Boalt Hall School of Law, University of California, Berkeley. 
